\title{
1 Compositional evolution of the upper continental crust through time, as constrained by
}

\section{2 ancient glacial diamictites}

3 Richard M. Gaschnig ${ }^{1 *}$, Roberta L. Rudnick ${ }^{1 * *}$, William F. McDonough ${ }^{1}$, Alan J. Kaufman ${ }^{2}$,

4 John Valley ${ }^{3}$, Zhaochu $\mathrm{Hu}^{4}$, Shan $\mathrm{Gao}^{4}$, Michelle L. Beck ${ }^{5}$

5 1. Department of Geology, University of Maryland, College Park, MD 20742

2. Department of Geology and Earth System Science Interdisciplinary Center, University of Maryland, College Park, MD 20742

3. Department of Geoscience, University of Wisconsin - Madison, Madison, WI 53706

4. State Key Laboratory of Geological Processes and Mineral Resources, China University

of Geosciences, Wuhan, China 430074

5. Department of Biological Sciences, Virginia Polytechnic Institute and State University, Blacksburg, VA 24061

$13 *$ Now at School of Earth and Atmospheric Sciences, Georgia Institute of Technology, 14 Atlanta, GA 30332

\section{ABSTRACT}

The composition of the fine-grained matrix of glacial diamictites from the Mesoarchean,

19 Paleoproterozoic, Neoproterozoic, and Paleozoic, collected from four modern continents, reflect

20 the secular evolution of the average composition of the upper continental crust (UCC). The

21 effects of localized provenance are present in some cases, but distinctive geochemical signatures

22 exist in diamictites of the same age from different localities, suggesting that these are global 
23 signatures. Archean UCC, dominated by greenstone basalts and less so komatiites, was more

24 mafic, based on major elements and transition metal trace elements. Temporal changes in

25 oxygen isotope ratios, rare earth elements, and high field strength elements indicate that the UCC

26 became more differentiated and that tonalite-trondhjemite-granodiorite suites became less

27 important with time, findings consistent with previous studies. We also document the

28 concentrations of siderophile and chalcophile elements (Ga, Ge, Cd, In, Sn, Sb, W, Tl, Bi) and

29 lithophile Be in the UCC through time, and use the data for the younger diamictites to construct a

30 new estimate of average UCC along with associated uncertainties.

\section{Introduction}

The Earth is unique amongst other terrestrial planets in our solar system in that it has

34 continents, which are composed of silicic crust distinct from the basalts that dominate Earth's

35 ocean basins and the crust of other planets. Continental crust reflects differentiation associated

36 with plate tectonics on Earth (Taylor and McLennan, 1985; Rudnick, 1995; Condie and Kröner,

37 2013). How continents form and how they have grown through Earth's history remain salient

38 first-order questions in Earth science (Committee on Grand Research Questions in the Solid-

39 Earth Sciences, National Research Council, 2008). A necessary starting point to deciphering

40 how continents form is knowledge of their bulk composition. The continental crust, especially

41 the upper crust, is enriched in incompatible elements, by as much as a thousand fold relative to

42 the mantle, and thus it exerts a large influence on the planetary budget of these elements, despite

43 comprising a minute proportion $(0.5 \%)$ of the mass of the silicate Earth. These elements include

44 the heat producing elements $(\mathrm{K}, \mathrm{Th}$, and $\mathrm{U})$ that partially power mantle convection and drive

45 plate tectonics. Thus, quantifying the composition of the upper continental crust, the associated 
uncertainties on that composition, and how this composition may have changed through time is

47 an essential step in constraining the Earth's evolving power budget and, from that, mantle 48 dynamics.

Previous attempts to quantify the average composition of the upper continental crust

50 (UCC) have generally followed one of two approaches: systematic grid-based bedrock sampling,

51 or analysis of fine-grained sediments (or sedimentary rocks) such as shales and loess. The

52 former approach typically involves the collection and analysis of thousands of samples and has

53 been carried out in the Canadian Shield (Eade and Fahrig, 1973; Shaw et al., 1976; Shaw et al.,

54 1967), Russia (Borodin, 1998; Ronov and Yaroshevsky, 1967, 1976), China (Gao et al., 1998),

55 and Japan (Togashi et al., 2000). The latter approach assumes that natural geological

56 (sedimentary) processes provide a robust average of insoluble elements in the provenance of the

57 sediments, and has been used in many studies aimed at tracking the compositional evolution of

58 the UCC (McLennan et al., 1979,1980, 1983; Taylor and McLennan, 1985, 1995; Nance and

59 Taylor, 1976, 1977; Wronkiewicz and Condie, 1987, 1989, 1990; Peucker-Ehrenbrink and Jahn,

60 2001; Kamber et al., 2005; Chauvel et al., 2014; Sauzeat et al., 2015). Most of these studies use

61 either shale, glacially-derived loess, or desert loess to infer the average composition of the UCC,

62 which works well for insoluble elements, but not for soluble elements. Although the cold

63 temperatures and largely physical weathering that produce the glacial loess limits loss of the

64 soluble elements compared with shales, such loess still records a weathering signature (Gallet et

65 al., 1998), and both types of loess are also affected by wind-driven particle sorting that

66 fractionates heavy minerals, which may dominate the budgets of certain elements (e.g., Ti, $\mathrm{Zr}$,

67 Hf, Sn) (Barth et al., 2000; Liu et al., 1993; McLennan, 2001; Taylor et al., 1983, Chauvel et al., 68 2014; Sauzeat et al., 2015). 
By contrast, use of till or its lithified equivalent, glacial diamictite, may avoid many of

70 the above problems. Like loess, till is produced by physical weathering and thus, may be

71 expected to provide useful information on the soluble element concentrations of the UCC. Unlike

72 loess, there is minimal sorting, as tills are not reworked by wind (or water). Goldschmidt (1933;

73 1958) first suggested the utility of related glacial loam as a proxy for the average composition of

74 the UCC and the use of till for this purpose was recently explored by Canil and Lacourse (2011)

75 in a study of Quaternary valley till in the Canadian Cordillera, who showed that the tills provided

76 robust averages of the bedrock in the valleys the glaciers sampled.

77 Here, we report the major, trace element and oxygen isotopic compositions of pre-

78 Cenozoic diamictites deposited by continental ice sheets, and use these diamictites to evaluate

79 the compositional evolution of the UCC, for both soluble and insoluble elements, as well as

80 elements for which few data existed previously (e.g., Be, Ga, Ge, Cd, In, Sn, Sb, W, Tl, Bi). The

81 diamictites studied here were identified by previous workers as being of glacial origin based on

82 the presence of faceted and striated clasts, the presence of dropstones in associated laminated

83 sediments, as well as aspects of stratigraphic facies architecture (e.g., Hambrey and Harland,

84 1981). We hereafter refer to these rocks as diamictites, with the understanding that all samples

85 investigated here have been proposed to be of glacial origin.

\section{2. Methods}

\subsection{Samples and their preparation}

Glacial diamictites deposited by continental ice sheets are recognized around the world

89 from four pre-Cenozoic intervals $(\sim 2.9,2.4-2.2,0.75-0.57$, and $0.30 \mathrm{Ga})$; we sampled diamictites 
90 from all four intervals on several modern continents. Stratigraphic units, ages, localities, and

91 references to the original investigations of these units are given in Table 1.

92 The samples investigated here comprise two rock types: (1) most samples comprise

93 massive (i.e., un-stratified) diamictite, which consists of muddy to sandy matrix material with

94 clasts ranging from pebble to cobble size, and (2) a few samples are dropstone-bearing argillites,

95 which are fine-grained stratified sedimentary rocks spatially associated with the diamictites. In

96 both cases, our analytical campaign focused on the fine-grained matrix material. Pieces with

97 fewer clasts were selected from each sample and crushed to chips in an alumina jaw crusher.

98 Any chips containing clasts larger than $\sim 5 \mathrm{~mm}$ were then removed by hand. A fraction of the

99 remaining material was then ground to a fine powder in an alumina swing mill. We endeavored

100 to produce 100 grams of powder for each sample, although this was not possible with some clast-

101 rich varieties.

102 In addition to preparing individual samples for analysis, we also prepared composite

103 samples of each stratigraphic unit, with the exceptions of the Paleoproterozoic Pecors,

104 Neoproterozoic Blasskranz, and Ordovician Pakhuis formations, for which we have no more than

105 two samples each. Each composite sample consists of equal weights of powder from each

106 individual sample of a stratigraphic unit that was thoroughly mixed together. These composites

107 are intended to serve as a new upper crustal reference suite of samples, comparable to PAAS

108 (post-Archean Australian shale; Nance and Taylor, 1976) and NASC (North American shale

109 composite; Haskin et al., 1966), and represent average compositions of the glacially sampled

110 upper crust found in each stratigraphic unit. The composites are available for further

111 investigations upon request to the second author.

\section{$112 \quad 2.2$ X-ray Fluorescence Analysis}


$114 \mathrm{XRF}$ at Franklin and Marshall College. Loss of ignition (LOI) was first determined at $900^{\circ} \mathrm{C}$.

115 From the resulting anhydrous powder, $0.4 \mathrm{~g}$ were mixed with $3.6 \mathrm{~g}$ of lithium tetraborate flux

116 and fused in a platinum crucible. The fusion disc was used for measurement of major elements,

117 along with Sr, Zr, V, and Cr. Other trace elements were measured on a powder briquette made

118 with copolywax binder. Analyses were conducted on a PANalytical 2404 X-ray XRF vacuum

119 spectrometer with a $4 \mathrm{~kW}$ super sharp X-ray tube. Major element results for the composite

120 samples are new, whereas results for the individual samples were previously reported in

121 Gaschnig et al. (2014) and are provided here for completeness (Table 2). Trace elements by

$122 \mathrm{XRF}$ are reported and discussed in the Supplemental Material.

\section{$123 \quad 2.3$ ICP-MS analysis}

\section{2.3.1 Sample digestion}

Most samples were digested by conventional high pressure $\mathrm{HF} / \mathrm{HNO}_{3}$ dissolution in

126 Teflon Parr bombs, closely following the methods of Zhang et al. (2010b). For each sample, fifty

127 milligrams of powder was weighed into a bomb along with $1 \mathrm{~mL}$ and $3 \mathrm{~mL}$ of concentrated

$128 \mathrm{HNO}_{3}$ and $\mathrm{HF}$, respectively. Bombs were then capped and placed in an oven for at least 4 days

129 at $\sim 180^{\circ} \mathrm{C}$. Bombs were then opened and acids were evaporated on a hot plate. Two $\mathrm{mL}$ of

130 concentrated $\mathrm{HNO}_{3}$ were added to the salt and evaporated, followed by $1 \mathrm{~mL}$ of $\mathrm{HNO}_{3}$ with 2

$131 \mathrm{~mL}$ of $\mathrm{H}_{2} \mathrm{O}$. Bombs were then capped and returned to the oven for one day at $150^{\circ} \mathrm{C}$. Samples

132 were transferred to centrifuge capsules and diluted to $15 \mathrm{~mL}$ using $2 \% \mathrm{HNO}_{3}$ containing a trace

133 of HF. 
A subset of samples (Paleoproterozoic samples from Wyoming and Ontario and

135 Paleozoic samples from Bolivia) was digested using the $\mathrm{NH}_{4} \mathrm{HF}_{2}$ method developed by Zhang et 136 al. (2010a). In this method, $\sim 0.2 \mathrm{~g}$ of purified $\mathrm{NH}_{4} \mathrm{HF}_{2}$ was added to $0.05 \mathrm{~g}$ of sample powder 137 with a drop of water in a Teflon screw-top Savillex beaker. Beakers were placed in an oven for 13812 hours at $\sim 230^{\circ} \mathrm{C}$. Upon returning to room temperature, $2 \mathrm{~mL}$ of $\mathrm{HNO}_{3}$ were added to the 139 solid salt and the beakers were capped and placed on the hot plate at $160^{\circ} \mathrm{C}$ for at least an hour.

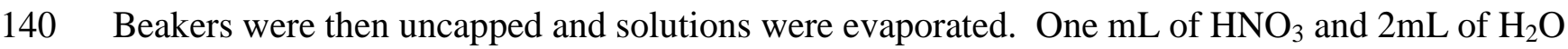
141 were added to the salt and the beaker was capped and placed on the hot plate for at least 6 hours. 142 Samples were transferred to centrifuge capsules and diluted to $15 \mathrm{~mL}$ with $2 \% \mathrm{HNO}_{3}$ containing 143 a trace of $\mathrm{HF}$.

144 Due to the large range in concentration of the elements analyzed (spanning five orders of 145 magnitude, with $\mathrm{Fe}$ and $\mathrm{Bi}$ as end members) two dilutions were prepared for analysis from the 146 master sample aliquot. The first dilution was prepared using $0.5 \mathrm{~mL}$ of master solution, adding

$1470.5 \mathrm{~mL}$ of an indium standard solution (as an internal drift corrector), and diluting to $15 \mathrm{~mL}$ with $1482 \% \mathrm{HNO}_{3}$ containing a trace of $\mathrm{HF}$ to prevent precipitation of the highly insoluble high field 149 strength elements. The second dilution was prepared by taking $1 \mathrm{~mL}$ of the first solution and 150 diluting this to $7.5 \mathrm{~mL}$ with $2 \% \mathrm{HNO}_{3}$. The dilutions were analyzed within 24 hours of 151 preparation in order to avoid precipitation of elements having low solubilities.

$152 \quad$ 2.3.2 ICP-MS protocols Most samples were analyzed for trace elements on a Thermo-Finnigan Element 2 high 154 resolution-ICP-MS in the Department of Geology at the University of Maryland. Instrumental 155 parameters are given in Supplemental Table A.1. Samples were analyzed with aliquots of USGS 156 whole-rock standards AGV-2, BHVO-1, GSP-1, and W-2 that were prepared at the same time as 
157 the samples. Elemental concentrations in samples were determined by constructing calibration

158 curves with the four USGS standards. Precision and accuracy were evaluated by repeated

159 analysis of separately dissolved AGV-2 aliquots treated as unknowns and are reported in Table

160 3. Precision was better than $4 \%$ relative standard deviation $(1 \sigma)$ for the majority of elements.

A small subset of samples (those from the Konnarock, Nantuo and Gucheng formations)

162 were analyzed on an Agilent 7700x quadrupole ICP-MS in the State Key Laboratory for

163 Geological Processes and Mineral Resources at the China University of Geoscience in Wuhan,

164 China and these are shown in italics in Table 2. Instrumental parameters are given in

165 Supplemental Table A.1. Calibration was conducted using multi-element standard solutions to

166 create a calibration line, and then adjusting this calibration after analysis of dissolved whole-rock

167 standards. Precision and accuracy are discussed in $\mathrm{Hu}$ and Gao (2008).

\subsubsection{Standard addition analysis}

A subset of samples was analyzed by standard addition ICP-MS for Ga, Ge, Mo, Cd, In,

$170 \mathrm{Sn}, \mathrm{Sb}, \mathrm{W}, \mathrm{Tl}$, and $\mathrm{Bi}$, since the concentrations of these elements are relatively poorly

171 constrained in the whole-rock standards used for calibration. Two spikes were prepared from

172 single-element standard solutions, one containing Ga, Ge, Mo, Sn, and W, and one containing

$173 \mathrm{Cd}, \mathrm{In}, \mathrm{Sb}, \mathrm{Tl}$, and $\mathrm{Bi}$. These two spikes were prepared due to the large difference in

174 concentrations found in typical crustal rocks and the potential for polyatomic interferences

175 between the groups (e.g., Mo-oxides on Cd). Four solutions were analyzed per sample (for a

176 given spike) consisting of: 1) a total analytical blank; 2) an unspiked aliquot of sample; 3) a

177 spiked aliquot of sample; and 4) an aliquot of a sample spiked with twice the volume of spike as

178 the previous one. All aliquots were also spiked with a Rh solution, which was used for internal

179 drift correction. Precision and accuracy of this method based on analyses of AGV-2 as an 
180 unknown are presented in Table 3. Further details of this approach, including data for other

181 standard reference materials, are given in Gaschnig et al (2015).

\subsection{Oxygen isotope analysis}

Whole-rock powders were analyzed for oxygen isotope ratios at the University of

184 Wisconsin-Madison by laser fluorination (Valley et al., 1995) using an air-lock sample chamber

185 (Spicuzza et al., 1998) with $\mathrm{BrF}_{5}$ as a reagent and a $25 \mathrm{~W} \mathrm{CO}_{2}$ laser $(\lambda=10.2 \mu \mathrm{m})$. By this

186 means, 2-3 mg samples of powder were outgassed at vacuum overnight and fluorinated

187 individually so as to prevent cross-contamination. Evolved oxygen was cryogenically cleaned,

188 passed through heated $\mathrm{Hg}$ vapor, and converted to $\mathrm{CO}_{2}$ over hot graphite for analysis. Isotope

189 ratios were measured on a Finnigan MAT 251 dual inlet mass spectrometer and are reported in

190 standard permil notation relative to VSMOW (Vienna Standard Mean Ocean Water). Measured

191 values were standardized using the UWG-2 garnet standard $\left(\delta^{18} \mathrm{O}=5.80 \%\right.$ VSMOW; Valley et

192 al., 1995). Overall reproducibility of the standard during the analytical sessions was +/- 0.18\%o

193 (2 SD).

194 3. Results

1953.1 Major elements

196 The major element compositions of siliciclastic sediments such as diamictites reflect the

197 relative proportions of quartz to feldspars and clays/phyllosilicates, and the majority of

198 diamictites falls along the expected mixing trend in a plot of $\mathrm{SiO}_{2}$ vs. $\mathrm{Al}_{2} \mathrm{O}_{3}$ (Fig 1a). Several

199 samples deviate from this trend and are characterized by either unusually high $\mathrm{CaO}$ or $\mathrm{Fe}_{2} \mathrm{O}_{3}(\mathrm{~T})$

200 (Figs. 1b and 1c). Although these outlier samples encompass all four age groups, they all share a

201 common origin in southern Africa. The high $\mathrm{CaO}$ samples also have high LOI values (see 
202 supplemental figure A.2), consistent with high levels of carbonate. The high levels of carbonate

203 and Fe have a dilution effect on the other major elements.

\section{$204 \quad 3.2$ Trace elements}

Trace element concentrations are plotted in Figures 2-4, organized by element groups. In

206 order to account for the effects of dilution from quartz, carbonate, or Fe on absolute abundances

207 of trace elements (see above), samples are first normalized to the average UCC abundance of

$208 \mathrm{Al}_{2} \mathrm{O}_{3}(15.26 \%$ ) of Rudnick and Gao (2003). Aluminum is used for this purpose because it is an

209 immobile element with a relatively restricted range in crustal igneous rocks (i.e., both basalts and

210 granites commonly have $\sim 15 \mathrm{wt} \% \mathrm{Al}_{2} \mathrm{O}_{3}$ ). This normalization is done by dividing 15.26 by the

211 measured $\mathrm{Al}_{2} \mathrm{O}_{3}$ in each sample, which results in a value greater than one for this "adjustment

212 factor" in samples that are affected by quartz, carbonate, or Fe dilution. We then multiply the

213 concentrations for each trace element by the adjustment factor. Data for individual elements are

214 then normalized to the average UCC of Rudnick and Gao (2003) (hereafter referred to as

$215 \mathrm{UCC}_{\mathrm{RG}}$ ) (with the exception of the chondrite normalized left half of Fig. 2), which provides a

216 frame of reference. For the sake of clarity, only composites are plotted in Figures 2-4. This is

217 justified by the close comparison between the calculated medians of individual samples for a

218 given formation and their composites. Further comparison of the individual sample results to the

219 composites is shown in supplemental Figure A.1.

$220 \quad$ 3.2.1 Rare earth elements (REE)

The REE are incompatible, insoluble lithophile elements that show a systematic increase

222 in compatibility with increasing atomic number, with the exception of Eu, which mirrors the

223 behavior of $\mathrm{Ca}$ and $\mathrm{Sr}$ when in a 2+ oxidation state. REE patterns, including Y (which behaves 
224 like a heavy REE and is plotted between Ho and Er), are shown in Figure 2. The diamictites all

225 show chondrite-normalized REE patterns (Figs. 2a) that are characterized by light REE (LREE)-

226 enrichment and negative Eu anomalies (Eu anomaly or $\mathrm{Eu} / \mathrm{Eu} *=\left(\mathrm{Eu} /\left(\mathrm{Gd}^{*} \mathrm{Sm}\right)^{0.5}\right)$, with all

227 concentrations normalized to chondrite), save one Mesoarchean sample that has a positive Eu

228 anomaly. Differences are more apparent when the results are normalized to $\mathrm{UCC}_{\mathrm{RG}}$ (Figs. $2 \mathrm{~b}$ ).

229 Three of the Mesoarchean composites have normalized REE abundances and LREE to heavy

230 rare earth element (HREE) fractionation similar to that of $\mathrm{UCC}_{\mathrm{RG}}$, whereas the fourth is depleted

231 in the LREE but not the HREE relative to $\mathrm{UCC}_{\mathrm{RG}}$. All Archean composites are enriched in $\mathrm{Eu}$

232 relative to $\mathrm{UCC}_{\mathrm{RG}}$. The majority of the Paleoproterozoic composites show normalized

233 concentrations and LREE to HREE fractionation comparable to $\mathrm{UCC}_{\mathrm{RG}}$, whereas Eu may be

234 slightly enriched or depleted relative to $\mathrm{UCC}_{\mathrm{RG}}$. The Neoproterozoic composites differ from the

235 older ones in that many show a positive slope when normalized to $\mathrm{UCC}_{\mathrm{RG}}$, indicating less

236 fractionation between the LREE and HREE, and all are Eu depleted. In addition, the

237 Neoproterozoic Idaho composite is distinctly more enriched in all REE than the other composites

238 of all ages. The Paleozoic composites are indistinguishable from the Neoproterozoic composites,

239 although Dwyka West has lower overall abundances and is not depleted in Eu.

\subsubsection{Transition and post-transition metals and metalloids}

241 The transition metals are generally compatible, may exhibit multiple valence states, and

242 may show lithophile, chalcophile, and/or siderophile characteristics. The post-transition metals

243 and metalloids exhibit both compatible and incompatible behavior and are primarily chalcophile.

244 The transition metal concentrations change as a function of the age of the sediment (Fig. 3a).

245 Mesoarchean composites are generally enriched in all transition metals relative to $\mathrm{UCC}_{\mathrm{RG}}$ but the

246 enrichment is significantly greater for $\mathrm{Cr}$ and $\mathrm{Ni}$ relative to the other metals. Paleoproterozoic 
247 composites show mild enrichment in $\mathrm{Cr}$, but otherwise are similar to $\mathrm{UCC}_{\mathrm{RG}}$. Neoproterozoic

248 composites are generally depleted in $\mathrm{Cr}, \mathrm{Co}$, and $\mathrm{Ni}$ but show similar Sc and V concentrations to

$249 \mathrm{UCC}_{\mathrm{RG}}$. Of the Paleozoic composites, the western Dwyka shows significant enrichment in all

250 transition metals, comparable to the Mesoarchean composites. The other Paleozoic composites

251 have transition metal levels overlapping those of the Neoproterozoic composites and similar to

$252 \mathrm{UCC}_{\mathrm{RG}}$.

The post-transition metals and metalloids are plotted, along with transition metals $\mathrm{Cu}$ and

$254 \mathrm{Zn}$, in Figure 3b. Copper concentrations vary more than those of all other elements (roughly two

255 orders of magnitude). Although the Mesoarchean composites are all enriched in $\mathrm{Cu}$, the younger

256 composites show both enrichment and depletion relative to $\mathrm{UCC}_{\mathrm{RG}}$. Paleoproterozoic composites

257 are particularly notable for the large range of normalized $\mathrm{Cu}$ concentrations observed. Zinc is

258 also quite variable in the Paleoproterozoic composites but composites from other periods show a

259 narrower range of concentrations and are consistently enriched relative to $\mathrm{UCC}_{\mathrm{RG}}$. Cadmium

260 also shows significant variability but tends to be enriched in most composites relative to $\mathrm{UCC}_{\mathrm{RG}}$.

261 Compared to all other post-transition metals, concentrations of $\mathrm{Ga}$ and $\mathrm{In}$, which belong to the

262 same group as $\mathrm{Al}$ on the Periodic Table, show little variability and match $\mathrm{UCC}_{\mathrm{RG}}$ estimates.

263 Germanium concentrations vary widely, especially in the Paleoproterozoic and Mesoarchean

264 composites, and are both enriched and depleted relative to $\mathrm{UCC}_{\mathrm{RG}}$; there is no correlation

265 between $\mathrm{Ge}$ and $\mathrm{SiO}_{2}$ contents. Tin is depleted relative to $\mathrm{UCC}_{\mathrm{RG}}$ in the Mesoarchean and some

266 of the Paleoproterozoic composites, but is enriched in all other composites. Antimony

267 concentrations are highly variable in diamictites of all time periods, and show no obvious trend

268 with age, but tend to be enriched in the diamictites relative to $\mathrm{UCC}_{\mathrm{RG}}$.

269

\subsubsection{Alkali and alkaline earth elements}


The alkali and alkaline earth elements are incompatible and relatively soluble lithophile

271 elements; their normalized concentrations in the diamictite composites are shown in Fig. 4a.

272 Lithium is enriched relative to $\mathrm{UCC}_{\mathrm{RG}}$ in nearly all composites, and $\mathrm{Rb}$ is generally enriched in

273 all post-Archean samples. Cesium is highly variable, showing both large enrichments and

274 depletions in different composites with no obvious trend with age. Beryllium concentrations

275 appear to increase with age. Strontium is depleted relative to $\mathrm{UCC}_{\mathrm{RG}}$ in all composites save the

276 carbonate-rich Neoproterozoic Ghaub Formation. Barium concentrations show a relatively

277 narrow range in the diamictites, with some suggestion of an increasing concentration over time

278 with respect to $\mathrm{UCC}_{\mathrm{RG}}$.

279 3.2.4 High field strength elements (HFSE)

280 The HFSE are incompatible and primarily lithophile elements, although Mo and W may

281 show chalcophile and siderophile characteristics, respectively. Normalized HFSE concentrations

282 for the composites are shown in Fig. 4b. Zirconium and Hf concentrations show limited

283 variability and are close to $\mathrm{UCC}_{\mathrm{RG}}$, with the exception of the Neoproterozoic Pocatello (Idaho)

284 and Blaubeker formations that are enriched in $\mathrm{Zr}$ and $\mathrm{Hf}$. Niobium and Ta concentrations vary

285 more widely and show an increase with time relative to $\mathrm{UCC}_{\mathrm{RG}}$. Several Neoproterozoic

286 composites show significant enrichment in $\mathrm{Nb}$ and $\mathrm{Ta}$, and the enrichment is especially large

287 ( 10 times $\left.\mathrm{UCC}_{\mathrm{RG}}\right)$ in the Pocatello composite. Molybdenum concentrations show significant

288 variability within and between the different time periods, but are generally higher in the

289 Mesoarchean and Paleoproterozoic than the Neoproterozoic and Paleozoic, with the exception of

290 the Mo-enriched western Dwyka composite. Tungsten concentrations are depleted in the

291 Mesoarchean and Neoproterozoic composites relative to $\mathrm{UCC}_{\mathrm{RG}}$, but are similar to or enriched

292 relative to $\mathrm{UCC}_{\mathrm{RG}}$ in the Paleoproterozoic and two of the three Paleozoic composites. 
The heavy post-transition metals (Tl, $\mathrm{Pb}$, and $\mathrm{Bi}$ ) (Fig. 4c) are incompatible elements

295 with both lithophile and chalcophile characteristics. The actinides (Th and U) are incompatible

296 lithophile elements. Concentrations of all five elements vary widely in the composites of all

297 periods except the Paleozoic. Thallium is either similar to or depleted relative to $\mathrm{UCC}_{\mathrm{RG}}$ in all

298 periods. Lead concentrations are either higher or lower than $\mathrm{UCC}_{\mathrm{RG}}$ and show no temporal

299 trend. Bismuth concentrations are enriched relative to $\mathrm{UCC}_{\mathrm{RG}}$ for most composites. Thorium and

$300 \mathrm{U}$ concentrations are depleted in the Mesoarchean but enriched in the other periods. Th/U

301 increases systematically from the Mesoarchean, which has lower Th/U than $\mathrm{UCC}_{\mathrm{RG}}$, to the

302 Neoproterozoic, which has higher Th/U than $\mathrm{UCC}_{\mathrm{RG}}$. By contrast, Th/U of the Paleozoic samples

303 are similar to $\mathrm{UCC}_{\mathrm{RG}}$.

3043.3 Oxygen isotopes

$305 \quad$ Figure 5a shows the $\delta^{18} \mathrm{O}$ values for individual glacial diamictite powders as a function of 306 age, after filtering the data set to exclude samples with LOI values greater than $7 \%$. (We exclude 307 these samples to eliminate the effects of carbonate, which leads to abnormally high $\delta^{18} \mathrm{O}$ values.

308 See supplemental figure A.2 for justification of this cut-off criterion). The oxygen isotope ratios

309 of the diamictites tend to become heavier and more variable with time. Values of $\delta^{18} \mathrm{O}$ are the

310 lowest in the Archean diamictites, which overlap with the modern mantle. Most of the

311 Paleoproterozoic diamictites have $\delta^{18} \mathrm{O}$ values that overlap with those of the higher $\delta^{18} \mathrm{O}$ Archean

312 diamictites, but diamictites from the Makganyene and Duitschland formations from South Africa

313 have considerably higher $\delta^{18} \mathrm{O}$, ranging from 13 to $18 \%$. The majority of Neoproterozoic

314 samples have values between 10 and 15\%o. Several of the Paleozoic samples overlap with the

315 main Neoproterozoic group but a few samples have lower $\delta^{18} \mathrm{O}$ values. 
Figure $5 \mathrm{~b}$ shows $\delta^{18} \mathrm{O}$ of the diamictites versus their chemical index of alteration values

317 (CIA $=$ molar $\mathrm{Al}_{2} \mathrm{O}_{3} /\left(\mathrm{Al}_{2} \mathrm{O}_{3}+\mathrm{CaO}^{*}+\mathrm{K}_{2} \mathrm{O}+\mathrm{Na}_{2} \mathrm{O}\right)$, where $\mathrm{CaO} *$ is corrected for apatite and

318 carbonate; carbonate correction using approach of McLennan, 1993) (Nesbitt and Young, 1982),

319 which are a measure of chemical weathering intensity (see below). While a positive correlation

320 is present for the Neoproterozoic and Paleozoic diamictites, $\delta^{18} \mathrm{O}$ and CIA are largely

321 dffecoupled in the older diamictites. In particular, the Mesoarchean samples have very high CIA but mantle-like $\delta^{18} \mathrm{O}$.

\section{4. Discussion}

The efficacy of using glacial diamictites to track changes in the average UCC

325 composition is contingent upon two main factors. First, the diamictites must preserve the

326 original composition of the eroded crustal material without being significantly modified by syn-

327 or post-depositional processes such as chemical weathering. Second, the diamictites must

328 consist of material pulverized by ice sheets from large continental areas, as opposed to

329 preferentially sampling local sources near the ice sheet terminus. We consider these two factors

330 below, and then discuss evidence in the diamictites for secular changes in the average UCC

331 composition and finally, use our new data to derive an average UCC composition, along with

332 uncertainties, and compare that with previous results.

\section{4.1 Identifying and seeing through the effects of chemical weathering}

334 Sediments and sedimentary rocks frequently show the effects of chemical weathering,

335 which obscures information about the bulk composition of their sources. Several geochemical

336 indices have been used to recognize chemical weathering effects, the most popular of which is

337 the chemical index of alteration. Fresh igneous rocks have CIA values ranging from 40 to 55 
338 and pure kaolinite and chlorite have a value of 100 , owing to their lack of $\mathrm{Ca}$, $\mathrm{Na}$, and $\mathrm{K}$.

339 Gaschnig et al. (2014) noted that the majority of diamictites have CIA values elevated above

340 those of igneous rocks; they also attributed the pervasive $\mathrm{Sr}$ depletion seen in the diamictites to

341 the influence of chemical weathering. This weathering signature appears to be inherited from the

342 sediment source in most cases, rather than reflecting post-depositional changes, or weathering

343 during glacial erosion and transport (Gaschnig et al., 2014; Li et al., 2016).

344 A weakness of using the CIA value to assess chemical weathering effects is its inability

345 to take into account the original bulk composition of the protolith. This is especially problematic

346 at low CIA because unweathered igneous rocks can show a range of CIA values: basalts tend to

347 have the lowest CIA, around 40, whereas granites have higher CIA, up to 55. One way of

348 extracting information on source lithologies from major element data of sedimentary rocks,

349 which also show the influence of chemical weathering, is to pair the CIA value with another

350 index called the ICV (index of chemical variability) (Cox et al., 1995), which is defined as ICV =

$351\left(\mathrm{TiO}_{2}+\mathrm{Fe}_{2} \mathrm{O}_{3}(\mathrm{~T})+\mathrm{MnO}+\mathrm{MgO}+\mathrm{CaO}+\mathrm{K}_{2} \mathrm{O}+\mathrm{Na}_{2} \mathrm{O}\right) / \mathrm{Al}_{2} \mathrm{O}_{3}$ (with all oxides as weight

352 percent). ICV values are higher for more mafic source lithologies and when plotted against CIA

353 values (Figure 6) (Potter et al., 2005), straight lines connecting a completely weathered end

354 member (pure kaolinite/chlorite) to average igneous compositions reflect weathering trends. The

355 majority of the diamictite data plot on a broad weathering trend consistent with an average

356 andesitic source region, which is close to the expected granodioritic average composition of the

357 UCC. However, many Mesoarchean and Paleoproterozoic samples fall along trends suggestive

358 of a basaltic or komatiitic average source composition, indicating that the UCC from these earlier 359 time periods was more mafic. 
Another method used for separating source composition from weathering affects in

361 sedimentary rocks was developed by Ohta and Arai (2007). This approach uses principle

362 component analysis to assign and weight all major element oxides into mafic (M), felsic (F), and

363 weathered (W) end members. Individual diamictites are plotted in this framework in Figure 7.

364 As in Figure 6, the majority of samples plot in a broad field reflecting a weathering trend

365 projecting to intermediate composition igneous protoliths, except for a select group of Paleozoic

366 Dwyka samples (the west Dwyka) and nearly all of the Archean samples. These samples form a

367 weathering trend that projects to a mafic igneous protolith. Thus, although the diamictites all

368 bear chemical weathering signatures of various intensities, it is possible to use their major

369 elements to identify a major change in the nature of the crust being weathered and eroded

370 between the Archean and Paleoproterozoic.

3714.2 Identifying and seeing through the effects localized or non-representative provenance

372 Research on modern and Pleistocene glacial erosion and sedimentation has shown that

373 large ice sheets are capable of transporting sediment great distances, but that sediment from

374 upstream sources may become diluted by material from nearby sources with increasing

375 downstream distance (e.g., Clark, 1987; Klassen, 1999; Hildes et al., 2004; Farmer et al., 2006).

376 Dispersal distance appears to be controlled primarily by basal ice velocity and bedrock

377 topography (Clark, 1987). The effects of localized provenance are seen on the geochemistry of

378 some of the diamictites. The two most prominent examples are found in the Pocatello Formation

379 and Dwyka Group. Diamictites from the Neoproterozoic Pocatello Formation are unusually

380 enriched in $\mathrm{Nb}$ and $\mathrm{Ta}$ (by an order of magnitude relative to $\mathrm{UCC}_{\mathrm{RG}}$, Fig. $4 \mathrm{~b}$ ), and the REEs,

381 especially the LREEs (enriched by a factor of two relative to $\mathrm{UCC}_{\mathrm{RG}}$, Fig. 2). These enrichments

382 reflect the contribution from local Neoproterozoic bimodal alkaline volcanic rocks formed 
383 during the rifting of Rodinia, which are strongly enriched in these elements (Yonkee et al.,

384 2014). The influence of these alkaline rocks is supported by the large number of detrital zircons

385 of the appropriate age found in this diamictite (Yonkee et al., 2014), and the high concentrations

386 of $\mathrm{Zr}$ and $\mathrm{Hf}$ (Fig. 4b). Despite this clear local signature, the Pocatello Formation also shares

387 distinctive chemical characteristics that are common to all Neoproterozoic diamictites, such as

388 the depletion of $\mathrm{V}, \mathrm{Sc}, \mathrm{Mo}$, and especially $\mathrm{Cr}$ and $\mathrm{Ni}$ relative to REE.

Another example of the influence of localized provenance is found in the Dwyka Group,

390 where major geochemical differences exist between diamictites collected in separate parts of the

391 Karoo Basin. Samples from the western Dwyka have significantly higher concentrations of the

392 compatible transition metals $(\mathrm{Sc}, \mathrm{V}, \mathrm{Cr}, \mathrm{Co}, \mathrm{Ni}, \mathrm{Cu}, \mathrm{Zn}, \mathrm{Mo}, \mathrm{Cd})$ and lower concentrations of the

393 REE than samples from the southeastern Dwyka. These chemical characteristics appear to

394 reflect differences in provenance governed by ice flow directions. Detrital zircons from the west

395 Dwyka samples are 2.0 Ga and older (Gaschnig et al., 2015), indicating that the ice in this region

396 was exclusively sampling the Archean interior of the Kaapvaal craton (plus the Paleoproterozoic

397 Bushveld Complex). By contrast, a large diversity of detrital zircon ages, ranging from Early

398 Paleozoic to Archean, are found in the southeastern portion of the Dwyka Group (Vorster, 2013),

399 indicating both a greater diversity of sediment sources and a dominance of Mesoproterozoic and

400 younger ages. Thus, the transition metal enrichments (Fig. 3a) and the major element evidence

401 for a much more mafic source rock (Fig. 7) for the west Dwyka diamictites relative to the

402 remainder of the Dwyka samples both reflect sampling of Archean crust by the Paleozoic

403 glaciers in the west.

404 Despite the influence of localized provenance seen in the geochemistry of certain samples

405 discussed above, there are common geochemical features seen globally amongst similarly aged 
samples. This is especially apparent for elements such as the REE, which show similar

407 fractionation patterns and abundances for each time period, and the transition metals, which

408 show relatively uniform levels of enrichment or depletion in each time period. Furthermore,

409 many of the other diamictites for which detrital zircons have been dated show age spectra with a

410 wide range of ages, indicating a diversity of sediment sources (e.g., Liu et al., 2008; Hofmann et

411 al., 2015). Consequently, the majority of the diamictites appear to consist of sediments drawn

412 from large continental areas, making them reliable proxies for the average UCC for many

413 elements. We next explore the key geochemical features seen amongst diamictites of different

414 ages.

\subsection{Secular changes in diamictite compositions}

416 Systematic secular changes in the compositions of the diamictites are observed that

417 reflect changes in the average composition of the UCC through time. We explore these changes

418 below in plots of elemental ratios versus age for insoluble elements in the composite samples

419 (Figs. 8 through 12), and measure the robustness of these changes through statistical analysis.

420 We used Kolmogorov-Smirnov tests and normality plots to determine if variables met the

421 assumptions of a parametric test and log transformed the ratios when necessary to improve

422 normality. We used MANOVA (multivariate analysis of the variance) to compare normally

423 distributed ratios among the four time periods and used post-hoc univariate ANOVAs and Tukey

424 tests to identify significant differences among periods. All tests were two-tailed and we set $\alpha=$

425 0.05. For ratios that were not normally distributed, we used a Kruskall-Wallis test to compare

426 ratios among the different time periods. Analyses were performed in PASW 18 (SPSS). Results

427 are provided in the Supplemental Tables A2 and A3. All of the element ratios examined differed

428 significantly among the four time periods (all $\mathrm{p}<0.05$ ), with the exception of $\mathrm{Gd} / \mathrm{Lu}$. 
As noted above, techniques using major element composition to separate sediment source

431 from weathering effects reveal that the Mesoarchean and some of the Paleoproterozoic

432 diamictites have distinctly more mafic provenances that include komatiites (Figs. 6 and 7).

433 Moreover, from the Archean to the present, diamictites show a secular decrease in the abundance

434 of the compatible first row transition metals (Sc, V, Cr, Co, and Ni, Fig. 3), a feature also

435 documented in Figure 4 of Gaschnig et al. (2014). These transition metals are contained

436 primarily in mafic minerals, and the depletion of these elements with decreasing age is consistent

437 with the UCC becoming less mafic with time. We can summarize this observation using the

$438 \mathrm{Ni} / \mathrm{Lu}$ ratio plotted against deposition age (Fig. 8a), where Lu is used as a reference element

439 having limited absolute variation (in the same way that $\mathrm{Al}$ is used in the multi-element plots in

440 Figs. 2-4). Ni/Lu ratios in Mesoarchean diamictites are distinctly higher than all other

441 composites, demonstrating that these diamictites were sourced from a UCC with high Ni content.

442 Diamictites from the post-Archean glaciations show successively lower Ni/Lu ratios (with the

443 exception of the western Dwyka samples previously discussed). These observations are

444 consistent with the UCC being more mafic in the Archean and becoming progressively more

445 differentiated and felsic in composition with time (Tang et al., 2016).

The $\mathrm{Th} / \mathrm{Sc}$ ratio is used to differentiate between mafic and felsic provenance of

447 sediments, given the compatibility of Sc and the incompatibility of Th in igneous systems (e.g.,

448 Taylor and McLennan, 1985). Sediments from granitic source rocks thus have higher Th/Sc

449 ratios than those from basaltic source rocks. The Mesoarchean diamictite composites show the

450 lowest $\mathrm{Th} / \mathrm{Sc}$ ratios, which is consistent with the other lines of evidence indicating a

451 predominantly mafic source (Fig. 8b). In contrast to the continuous change with time seen in the 
$452 \mathrm{Ni} / \mathrm{Lu}$ ratio, the $\mathrm{Th} / \mathrm{Sc}$ ratio increases between the Mesoarchean and Paleoproterozoic but does 453 not show a continuous secular trend.

$\mathrm{The} \mathrm{Eu} / \mathrm{Eu}^{*}$ ratio is another measure of intracrustal differentiation. This is because $\mathrm{Eu}^{2+}$ 455 enters feldspar relative to $\mathrm{Eu}^{3+}$, which leads to the development of a negative Eu anomaly $456\left(\mathrm{Eu} / \mathrm{Eu}^{*}<1\right)$ in evolved magmas derived from melting or differentiation within the crust of 457 typical thickness ( $\leq 35 \mathrm{~km}$ ) (e.g., Taylor and McLennan, 1985; Rudnick and Gao, 2003; Tang et 458 al., 2015). As with the Ni/Lu ratios, the diamictites show a continuous decrease in Eu/Eu* with 459 time (Fig. 8c). This suggests that intracrustal differentiation became increasingly important 460 through time and is consistent with a greater proportion of mafic, undifferentiated magmas 461 making up the bulk of the Archean UCC.

463 provenance, which, in turn, reflects its chemical weathering or alteration history. Low 464 temperature interactions with water at or near the Earth's surface drives the oxygen isotopic 465 compositions of rocks towards higher $\delta^{18} \mathrm{O}$ values, starting from the mantle $\delta^{18} \mathrm{O}$ value of $5.6+/$ $4660.3 \%$ (Mattey et al., 1994; Valley et al., 1998; Eiler, 2001; Grimes et al., 2011). As noted above, 467 the $\delta^{18} \mathrm{O}$ of the diamictites generally increase with time (Fig. 5a). The oxygen isotope 468 composition of Mesoarchean diamictites have both relatively low $\delta^{18} \mathrm{O}$ values and a limited 469 range (Fig. 5a). These samples overlap in part with the $\delta^{18} \mathrm{O}$ composition of the modern mantle 470 and are lower, on average, than the published values for Archean siliciclastic sediments compiled 471 by Payne et al. (2015) and Bindeman et al. (2016). The $\delta^{18} \mathrm{O}$ values of the Archean diamictites 472 are also decoupled from the CIA values, which are high ( $\sim 70$ to 90 ) (Fig. $5 b)$. The persistence of 473 the low Archean $\delta^{18} \mathrm{O}$ values suggests either that weathering processes did not significantly 474 contribute to their oxygen isotope compositions, or that Archean surface waters had a 
475 significantly different oxygen isotope composition than today (Knauth and Lowe, 2003;

476 Muehlenbachs, 1998).

477 The main exceptions to the increase in $\delta^{18} \mathrm{O}$ with time are the very high values from the 478 Paleoproterozoic Makganyene and Duitschland formations. These units tend to have high CIAs 479 and are dominated by marine sedimentary clasts (carbonate and chert), suggesting that their 480 heavy oxygen isotope compositions are influenced by incorporation of a greater proportion of 481 preexisting sediments compared to other diamictites that contain an assortment of clast types and 482 are often rich in igneous and meta-igneous clasts. The increase in the average $\delta^{18} \mathrm{O}$ values of the diamictites with time (Fig. 5a) and the 484 increase in the range of $\delta^{18} \mathrm{O}$ values after the Mesoarchean is broadly consistent with both the 485 igneous $\delta^{18} \mathrm{O}$ record provided by zircons (Valley et al., 2005) and the compilation of existing 486 whole-rock siliciclastic sedimentary data of Payne et al. (2015) and Bindeman et al. (2016). 487 Both studies attributed the parallel changes in the igneous and sedimentary oxygen isotope 488 record of continents to the increased production of clay and incorporation of it into sedimentary 489 and igneous rocks. This increase in clay production may have been driven by a combination of 490 crustal thickening and crustal growth, both of which led to greater amounts of emergent 491 continental material available for weathering (Arndt, 1999; Rey and Coltice, 2008; Gaillard et 492 al., 2011).

493 In summary, the above observations from major and trace elements indicate that the crust 494 sampled by the ice sheets in the Archean was more mafic and less differentiated compared to 495 later time periods. The similarity of these results to previous studies of Archean UCC 496 geochemistry based on shales and map-based methods (e.g., Taylor and McLennan, 1985; 2010; 497 Condie, 1993) strongly suggest that the diamictites are faithful proxies for the UCC composition. 
498 The presence of a negative Eu anomaly (albeit a small one) in all but one of the oldest diamictite

499 units is consistent with Condie's (1993) contention that the average Archean UCC had a negative

500 Eu anomaly, and its growth with time supports the hypothesis that intracrustal differentiation

501 increasingly became more important from late Archean onward (Taylor and McLennan, 1985).

502 The increase in $\delta^{18} \mathrm{O}$ values with time is also consistent (at least indirectly) with increasing

503 recycling of continental crust from the Mesoarchean onwards, possibly the result of a thicker and

504 more voluminous emergent crust (Payne et al., 2015).

\subsubsection{Changes in the concentrations of heat producing elements}

Thorium and $U$ are two of the three major heat-producing elements in the Earth. While

507 these elements are concentrated in the continental crust and depleted in the mantle, the amount

508 remaining in the mantle after crust extraction plays an important role in driving convection and

509 plate tectonics. It is for this reason, and their role as progenitors of several radiogenic $\mathrm{Pb}$

510 isotopes, that constraining the concentrations of Th and $\mathrm{U}$ in the upper crust is of great

511 importance to understanding Earth differentiation and evolution.

512 Thorium and $\mathrm{U}$ are similarly incompatible during mantle melting, so the $\mathrm{Th} / \mathrm{U}$ ratio in

513 juvenile crust is expected to match the mantle ratio. While Rudnick and Gao (2003) inferred an

514 average $\mathrm{Th} / \mathrm{U}$ of 3.8 for the UCC, there are reasons to believe that the abundance of these heat-

515 producing elements have changed through time. McLennan and Taylor (1980) and Taylor and

516 McLennan (1985) noted a secular increase of Th/U for fine-grained sedimentary rocks, with

517 average values between 3.5 and 4.0 for the Archean while Phanerozoic values were $\sim 5$. They

518 attributed this trend to increased recycling of sedimentary material under oxidized atmospheric

519 conditions after the Great Oxidation Event (GOE) around 2.4 Ga (e.g., Holland et al., 2006),

520 leading to conversion of $\mathrm{U}^{+4}$ to soluble $\mathrm{U}^{+6}$ and its loss from the UCC to the oceans through 
521 weathering. Similarly, Collerson and Kamber (1999) documented a complementary decrease in

522 the $\mathrm{Th} / \mathrm{U}$ of depleted mantle through the same interval, which they attributed to increased

523 oxidation of Earth's surface and preferential recycling of U.

The normalized concentration of Th in the diamictites shows a step-wise increase

525 between the Mesoarchean and Paleoproterozoic (Fig. 9a), which (as mentioned above) is

526 consistent with a more felsic and differentiated UCC after the Archean. On the other hand, the

527 concentration of $U$ shows a more subtle increase after the Archean and generally shows more

528 scatter (Fig. 9b). The Th/U ratios of the diamictites are lower in Archean and Paleoproterozoic

529 diamictites compared to those of the Neoproterozoic and Paleozoic (Fig 9c) but they do not show

530 a smooth temporal change. The Neoproterozoic samples are distinct in that they show both the

531 greatest variation and the highest average $\mathrm{Th} / \mathrm{U}$. The temporal changes in $\mathrm{Th} / \mathrm{U}$ reflect a

532 combination of the step-wise increase in Th after the Archean and the depletion of U in most of

533 the Neoproterozoic, Paleozoic, and one of the Paleoproterozoic (Duitschland) diamictites. The U

534 depletion is most likely the result of oxidative weathering. Overall, the diamictite results are

535 consistent with other UCC proxies in showing an upward redistribution of Th and U into the

536 UCC due to enhanced intracrustal differentiation after the Archean and then loss of U to the

537 oceans via oxidative weathering.

538 4.3.3 Changes in the fractionation of REEs

539 With the exception of Eu (discussed above), the REEs display coherent behavior during

540 geochemical processes due to their identical oxidation states (under igneous conditions) and

541 progressively decreasing ionic radii with increasing atomic number, which results in more

542 incompatible behavior of the LREEs compared to the HREEs. The pressure at which partial

543 melting and/or crystal fractionation occurs is one of the main processes controlling the 
544 fractionation of REEs, as the presence of garnet at higher pressures results in high LREE/HREE

545 ratios in melts in equilibrium with these minerals (Drummond and Defant, 1990). Such TTGs

546 (tonalite-trondhjemite-granodiorite associations) are a major constituent of Archean crust (e.g.,

547 Moyen and Martin, 2012). Ratios reflecting the fractionation between light, medium, and heavy

548 REEs as a function of time are shown in Figures 10a, c, and e. The Neoproterozoic Pocatello

549 (Idaho) diamictites and one of the Mesoarchean units (the Afrikander Formation of the

550 Witwatersrand Supergroup) are prominent outliers, which are attributable to the influence of

551 local incompatible element-enriched rift-related igneous rocks in the case of the former (Yonkee

552 et al., 2014) and a more mafic/ultramafic provenance of the latter (relative to the other Archean

553 units). Even excluding these outliers, La/Lu, representing overall LREE/HREE fractionation,

554 shows significant overlap amongst the four time periods (Fig. 10a). The LREEs show more

555 resolvable differences amongst the four periods, with a peak in $\mathrm{La} / \mathrm{Sm}$ in the Paleoproterozoic

556 followed by a drop to lower values in the Neoproterozoic and Paleozoic (Fig. 10c). Decreasing

557 fractionation of LREE with time is consistent with the shift from a granitic component

558 dominated by TTG magmatism in the earlier Archean and Hadean, to "modern-style" K-rich

559 granitic magmatism in the Neoarchean during a period of global cratonization (e.g., Whalen et

560 al., 2004; Condie and O’Neill, 2011; Arndt, 2013; Laurent et al., 2015), a shift that is observed in

561 a statistical analysis of the geochemistry of granites through time (Keller and Schoene, 2012).

562 The HREEs do not show significant differences in fractionation amongst the four time periods,

563 as seen in the $\mathrm{Gd} / \mathrm{Lu}$ (Fig. 10e) (the latter of which is supported by a statistical test indicating

564 data from the four time periods belong to the same population). While Archean TTGs have high

$565 \mathrm{Gd} / \mathrm{Lu}$, they also have low concentrations of HREEs relative to Archean basalts, which tend to

566 have flat HREE patterns (e.g., Condie, 1993). Thus, if the Gd/Lu of Archean diamictites reflects 
567 a mixture of basalt and TTG, this can explain the lack of fractionation between the Archean and 568 post-Archean UCC.

569 In addition to secular changes in the fractionation of LREEs, the concentrations of the 570 REEs (normalized to Al) change with time (Figs. 10b, d, and f). Although there is significant

571 overlap in La concentrations in the different time periods, Gd and especially Lu concentrations

572 increase in younger units. This temporal increase is likely a reflection of the increasingly felsic

573 and differentiated composition of the UCC, with the particularly marked changes in Lu (and

574 other HREEs) likely reflecting an increasingly smaller proportion of the UCC comprised of 575 HREE-depleted TTGs, as described above.

The $\mathrm{Sm} / \mathrm{Nd}$ and $\mathrm{Lu} / \mathrm{Hf}$ ratio are important in the study of planetary differentiation and

578 crust formation due to their radiogenic isotopic systems (i.e., decay of ${ }^{147} \mathrm{Sm}$ to ${ }^{143} \mathrm{Nd}$, ${ }^{146} \mathrm{Sm}$ to

$579{ }^{142} \mathrm{Nd}$, and ${ }^{176} \mathrm{Lu}$ to $\left.{ }^{176} \mathrm{Hf}\right)$. The $\mathrm{Sm} / \mathrm{Nd}$ ratios of the diamictites show an increase between the

580 Paleoproterozoic and Neoproterozoic (Fig. 11a), but this is an expected outcome given the

581 change in LREE fractionation seen in Figure 10c, and is probably attributable to the same causes.

582 The $\mathrm{Sm} / \mathrm{Nd}$ values of the diamictites are higher than in the UCC model of Rudnick and Gao

583 (2003), and references therein; however the diamictites do not exceed the range of other

584 published models, particularly the higher values of Kamber et al. (2005) and Chauvel et al.

585 (2014). The diamictites show a small increase in Lu/Hf with time, but also show a much greater

586 range for each period compared to $\mathrm{Sm} / \mathrm{Nd}$, probably due to the significantly different

587 geochemical behavior of Lu-Hf compared to the Sm-Nd pair (Fig. 11b).

588 4.3.5 HFSES 
The high field strength elements (HFSE), including Zr, Hf, Nb, and Ta, are highly

590 incompatible and enriched in the continental crust relative to the rest of the silicate Earth, but

591 they are also insoluble in aqueous fluids and consequently are fractionated from other similarly

592 incompatible elements (e.g., alkali and alkaline earth) during subduction zone processes (e.g.,

593 Pearce and Peate, 1995). In addition, the pairs Zr-Hf and Nb-Ta share oxidation states and near

594 identical ionic radii (4+, $715 \mathrm{pm} ; 5+, 640 \mathrm{pm}$, respectively) and are therefore difficult to

595 fractionate from one another. This coherent behavior has led to their use in studies of Earth

596 differentiation and crustal growth (e.g., Green et al., 1995; Barth et al., 2000; Pfander et al.,

597 2007; Hoffmann et al., 2011).

$\mathrm{Zr} / \mathrm{Hf}$ shows no secular variations, whereas $\mathrm{Nb} / \mathrm{Ta}$ and $\mathrm{La} / \mathrm{Nb}$ ratios of the diamictites

599 show a jump between the Paleoproterozoic and Neoproterozoic, with older diamictites having

600 lower $\mathrm{Nb} / \mathrm{Ta}$ and higher $\mathrm{La} / \mathrm{Nb}$ (Fig. 12). The latter observation is particularly interesting in light

601 of the temporal increase in La concentrations (Fig. 10b), as it requires an even greater increase in

$602 \mathrm{Nb}$ concentration in order to explain the increase in the $\mathrm{La} / \mathrm{Nb}$ ratio. The lower $\mathrm{Nb}$ seen in the

603 Paleoproterozoic and Mesoarchean diamictites is consistent with the other lines of evidence

604 listed above for a greater TTG influence on the Mesoarchean and Paleoproterozoic diamictites.

605 Although TTGs have a wide range of $\mathrm{Nb} / \mathrm{Ta}$ ratios, they generally are skewed towards

606 significantly lower ratios (e.g., Condie, 2005 Moyen and Martin, 2012). The secular changes in

$607 \mathrm{La} / \mathrm{Nb}$ and $\mathrm{Nb} / \mathrm{Ta}$ ratios point to differentiation processes driving the element fractionation. The

608 evidence from Hoffmann et al. (2011) and Marschall et al. (2013) is suggestive of a role for

609 residual rutile in TTG genesis (McDonough 1990; Rudnick et al., 2000).

6104.4 Reexamining the integrated average UCC 
The results presented here indicate that the UCC experienced a major change in

612 composition between the Mesoarchean and Paleoproterozoic glaciations, with more subdued

613 changes between the Paleoproterozoic and Neoproterozoic glaciations. There is no evidence

614 from the diamictites to indicate that the UCC changed significantly in composition between the

615 Neoproterozoic and Paleozoic, consistent with the lack of evidence for changes in crust

616 formation and modification processes in the last billion years. Therefore, the Neoproterozoic and

617 Paleozoic diamictites together should provide information on the average global UCC today.

618 Below, we compare the results obtained from the Neoproterozoic and Paleozoic diamictites to

619 previous estimates of the average UCC.

\subsubsection{The major element composition of the UCC}

Using the Neoproterozoic and Paleozoic diamictite samples as representative of the

622 present-day UCC, we calculate its average major element composition. Table 4 compares

$623 \mathrm{UCC}_{\mathrm{RG}}$ to two new estimates (unfiltered and filtered) for the average UCC based on two

624 appraisals of the Neoproterozoic and Paleozoic diamictite data. We report the median and the

625 median absolute deviation (MAD, defined as the median of the absolute deviations of the

626 measurements from the population median) rather than the arithmetic mean and standard

627 deviation because the former is less influenced by outliers. Both medians are normalized to

$628100 \%$ anhydrous (omitting the LOI) in order to properly compare them to existing major element

629 models. The first estimate (unfiltered) is calculated based on all Neoproterozoic and Paleozoic

630 diamictite samples. However, a weakness of this approach is that some Namibian

631 Neoproterozoic and the South African Paleozoic diamictites contain significant carbonate,

632 leading to high $\mathrm{CaO}$ (and $\mathrm{MgO}$ ) and unusually low values for the other major element oxides,

633 making them clear outliers, as exemplified in Figure 1. The second estimate (filtered) corrects 
634 for carbonate enrichment, with the median major element values providing a more robust

635 estimate of the average UCC composition.

636 Major element oxide medians for the Neoproterozoic and Paleozoic are shown

637 normalized to $\mathrm{UCC}_{\mathrm{RG}}$ in Figure 13. The filtered dataset has slightly lower $\mathrm{MgO}$ and $\mathrm{CaO}$ than

638 the unfiltered dataset but the other major element oxides are nearly identical and all are within

639 error of one another, indicating that carbonate-rich samples do not significantly skew the results.

640 Major differences between the Rudnick and Gao (2003) model and the diamictite-derived model

641 are the significantly lower $\mathrm{MgO}, \mathrm{CaO}$, and $\mathrm{Na}_{2} \mathrm{O}$, and marginally higher $\mathrm{K}_{2} \mathrm{O}$ of the latter. The

642 low $\mathrm{MgO}, \mathrm{CaO}$, and $\mathrm{Na}_{2} \mathrm{O}$ values are almost certainly the result of chemical weathering, as these

643 major elements are highly soluble and unlikely to be fixed in secondary minerals formed during

644 incongruent weathering (whereas $\mathrm{K}_{2} \mathrm{O}$ can be retained if kaolinite reacts with $\mathrm{K}^{+}$in pore water to

645 form illite, Fedo et al., 1995). The depletion of these elements relative to $\mathrm{UCC}_{\mathrm{RG}}$ is not

646 surprising given that this and other models cited therein are based largely on sampling crystalline

647 bedrock of continental shields. Use of crystalline rock compositions to determine the average

648 UCC ignores the fact that some fraction of the UCC consists, by definition, of sediments and

649 some fraction is chemically weathered. Accordingly, the diamictite-based model may provide a

650 more realistic estimate of the major element composition of the UCC. However, an important

651 question is how deeply this weathering signature extends into the crust. The thickness of UCC is

652 typically assumed to be no more than about $10 \mathrm{~km}$ (e.g., Taylor and McLennan, 1985), or the

653 approximate upper one third of the continental crust (e.g., Rudnick and Fountain, 1995). It is

654 likely that the signature of chemical weathering that is so obvious in the diamictites attenuates

655 with depth, but the shape of this attenuation profile is unknown and is difficult to determine. 
A new diamictite-based estimate for the trace element composition of the UCC is

658 presented in Table 4 based on the median values of the Neoproterozoic and Paleozoic samples.

659 Trace element medians are shown normalized to $\mathrm{UCC}_{\mathrm{RG}}$ in Figure 14. The filtered and

660 unfiltered dataset yield median values that are within the unfiltered median absolute deviations,

661 although the filtered dataset medians have smaller deviations. Compared to $\mathrm{UCC}_{\mathrm{RG}}$, the

662 diamictite-based model yields significantly higher $\mathrm{Li}, \mathrm{Rb}, \mathrm{Y}, \mathrm{MREE}$, and $\mathrm{HREE}$, all of which are

66320 to $60 \%$ higher. Transitional metals $\mathrm{Cr}, \mathrm{Co}$, and Ni, along with $\mathrm{W}$ and $\mathrm{Tl}$, are roughly $40 \%$

664 lower, and $\mathrm{Sr}$ and $\mathrm{Mo}$ are depleted by roughly $70 \%$ relative to $\mathrm{UCC}_{\mathrm{RG}}$. The depletions in $\mathrm{Sr}$ and

665 Mo have already been discussed and are attributed to the effects of chemical weathering

666 (Gaschnig et al., 2014) and the other deviations from $\mathrm{UCC}_{\mathrm{RG}}$ are still within the range of other

667 UCC models (Fig 14b). In particular, the diamictite medians for Li, Rb, Y, MREE, HREE, W,

668 and $\mathrm{Tl}$ are within uncertainty of the Australian alluvium-based model of Kamber et al. (2005),

669 and the median for $\mathrm{Li}$ is also similar to that of Teng et al. (2004) (35 ppm), as well as a newly

670 proposed average UCC value based on loess analyses (Sauzeat et al., 2015) (30.5 ppm). The

671 diamictite medians for $\mathrm{Cr}, \mathrm{Co}$, and $\mathrm{Ni}$, while lower than $\mathrm{UCC}_{\mathrm{RG}}$, are higher than the Shaw et al.

$672(1967 ; 1976)$ and Eade and Fahrig (1973) models based on bedrock sampling, but are

673 comparable to the Kamber et al (2005) model for $\mathrm{Cr}$ and $\mathrm{Ni}$. The diamictite median for $\mathrm{Bi}$ is

674 comparable to the previous estimate of Gao et al. (1998).

675 4.4.2.1 Concentrations of chalcophile and siderophile elements and Be in the UCC

676 Several infrequently analyzed chalcophile and siderophile elements (Ga, Ge, Cd, In, Sn,

$677 \mathrm{Sb}, \mathrm{W}, \mathrm{Tl}$, and $\mathrm{Bi}$ ) were analyzed (in most cases by standard addition) in this study in order to

678 better characterize their abundance in the UCC. We include the lithophile element Be in this

679 discussion because it is also infrequently analyzed and its abundance in the UCC is likewise less 
680 constrained. Molybdenum was also analyzed but shows strong effects of mobilization during

681 oxidative weathering in younger diamictites (Gaschnig et al., 2014), and consequently, it is only

682 discussed here in the context of its relationship with $\mathrm{Cd}$.

683 Of these elements, only Bi shows no statistical difference in concentration amongst the

684 four glacial epochs. Be and Sn show the only evidence for secular changes, and both have

685 higher concentrations in the Neoproterozoic and Paleozoic than Mesoarchean and

686 Paleoproterozoic (red and green symbols vs. blue and black symbols, respectively, in Fig 15 a,

687 b). This observation is consistent with greater differentiation of the crust through time, as both

688 elements are incompatible and concentrated in melt during partial melting and/or fractional

689 crystallization (e.g., Jochum et al., 1993; Ryan, 2002). Both elements correlate well with REEs,

690 particularly $\mathrm{Sm}$ in the case of $\mathrm{Be}$, and $\mathrm{Yb}$ in the case of Sn (Fig. 15a, b). Gallium correlates

691 strongly with the other Group 13 elements, Al and In, and also with Ti, Sn, and Be (Fig. 15c).

692 Germanium does not correlate with its Group 14 neighbors, Si and Sn, nor other trace elements,

693 but it correlates with Fe (Fig. 15d) in older diamictite samples. Mesoarchean and

694 Paleoproterozoic samples show correlations between Ge and Fe with differing slopes. This may

695 indicate that Ge (which is siderophile) is following reduced iron prior to the GOE, but that this

696 relationship does not hold for oxidized iron. Cadmium shows a complex but positive correlation

697 with Mo (Fig. 15e) with separate diamictite units showing different Cd vs. Mo slopes. The

698 presence or absence of oxidative weathering is the major process controlling Mo distribution in

699 the diamictites (Gaschnig et al., 2014) and Cd may be affected by the same processes, as it is

700 found in sulfides that are readily broken down by oxidative weathering and will remain in

701 solution in sulfide-poor waters (e.g., Calvert and Pedersen, 1993). Indium correlates well with

702 the MREE to HREEs and Y (Fig. 15f) and moderately well with Nb and Ta. Antimony does not 
703 correlate with other trace elements but shows a broad positive correlation with the CIA (Fig.

$70415 \mathrm{~g})$, suggesting that it may be adhering to clays during chemical weathering, although the lack

705 of correlation with other elements with a similar tendency (e.g., Rb) suggests several processes

706 may be at work. Tungsten correlates weakly with Th and Tl (Fig. 15g). Tl correlates well with

$707 \mathrm{Rb}$, and to a lesser extent with $\mathrm{Th}, \mathrm{Cs}$, and $\mathrm{K}$ (Fig. 15h). Bi does not correlate well with any

708 other element.

Using these correlations we calculate new average UCC concentrations for chalcophile

710 and siderophile elements. This follows the approach of McLennan (2001), where the existing

711 average UCC concentration for a well-constrained element (the "pinning" element), along with

712 associated uncertainties, is input into the regression equation $(\mathrm{x}$ in $\mathrm{y}=\mathrm{mx}+\mathrm{b})$ to calculate a new

713 average value for the chalcophile or siderophile element of interest. For this purpose we have

714 used both $\mathrm{UCC}_{\mathrm{RG}}$ and the median values derived from the diamictites for the concentrations of

715 the "pinning" elements. Propagating the errors on the slope and intercept of the regression, we

716 obtain the results shown in Table 5. An obvious weakness of this general approach is that the

717 newly-calculated concentrations are only as accurate as those for the pinning elements, and the

718 approach can only be used in cases where correlations exist. In general, the concentrations

719 derived from the regressions using different values for the pinning elements agree within

720 uncertainty, and also agree with those of $\mathrm{UCC}_{\mathrm{RG}}$, except for $\mathrm{Tl}$, with is significantly higher in the

721 latter.

722 4.4.3 Towards a UCC consensus

723 An emerging consensus on the average abundance for many major and trace elements in

724 the UCC can be seen in Figs. 13 and 14. All estimates of the average $\mathrm{SiO}_{2}, \mathrm{Al}_{2} \mathrm{O}_{3}, \mathrm{TiO}_{2}$, and

$725 \mathrm{~K}_{2} \mathrm{O}$ in the UCC are within $\pm 15 \%$. The same is true of $\mathrm{Ga}, \mathrm{Ge}, \mathrm{In}, \mathrm{La}, \mathrm{Ce}, \mathrm{Nd}, \mathrm{Pb}$, and Th. 
726 While much of the dispersion seen amongst UCC models for other elements is attributable to

727 chemical weathering effects, major differences are present amongst the insoluble first row

728 transition metals, as well as the MREE and HREE. These differences may be the result of

729 changing proportions of Archean to post-Archean UCC types in the sampled bedrock areas, in

730 the case of the grid-based models, and sediment sources in the case of the sediment-based

731 models.

\section{5. Conclusions}

Major and trace element and oxygen isotope compositions of ancient glacial diamictites

734 from the Mesoarchean, Paleoproterozoic, Neoproterozoic, and Paleozoic paint a portrait of

735 secular changes in the average composition of the upper continental crust with time. The

736 diamictites indicate that the Archean UCC was dominated by greenstone belt basalt, and

737 komatiite, with subordinate TTG and that the average UCC became more felsic and

738 differentiated with time. These changes are consistent with previous studies that have utilized

739 the geochemistry of shales, map-based reconstructions, and other approaches (e.g., Condie,

740 1993; Taylor and McLennan, 1985, 1995; Keller and Schoene, 2012), validating the utility of

741 glacial diamictites as UCC proxies.

742 We use the diamictite data to develop a new model for the modern UCC composition

743 based on the glacially sampled crust from the Neoproterozoic and Paleozoic eras. The major

744 elements trends show depletions in $\mathrm{Ca}, \mathrm{Na}$, and $\mathrm{Mg}$ and enrichment in $\mathrm{K}$ compared other UCC

745 models, which we attribute to the effects of chemical weathering, an intrinsic characteristic of the

746 UCC. How deep this signature extends into the crust is an important, unresolved question. The

747 diamictite-derived trace element estimates of UCC all fall within the range of existing models,

748 with the exceptions of large depletions in $\mathrm{Sr}$ and Mo that result from chemical weathering. 
750 concentrations show evidence for secular changes in the UCC, becoming more enriched with

751 time. Gallium behaves most similarly to Al, Ge follows Fe (for pre-Great Oxidation Event

752 samples), Cd follows Mo, In and Sn follow the MREEs, W follows Th, and Tl follows Rb.

753 Antimony correlates only with the CIA, and Bi does not correlate with any other element or

754 compositional parameter. New estimates for the UCC abundances of a subset of these elements

755 (Be, Ga, In, Sn, Tl) derived from correlations with better-known elements and from median

756 values for Paleozoic and Neoproterozoic diamictites are within uncertainty of $\mathrm{UCC}_{\mathrm{RG}}$, except for

757 Tl, which is significantly higher in the latter.

\section{Acknowledgements}

760 This research was supported by NSF EAR-1321954, NSF EAR-1144454, NSF FESD EAR-

761 1338810, and a grant from the State Key Laboratory of Geological Processes and Mineral

762 Resources at China University of Geosciences in Wuhan. We thank Nic Beukes, Paul Link, Lian

763 Zhou, Charlie Hoffmann, and Guy Narbonne for help with sampling and geologic interpretation;

764 Heidi Anderson for providing the Bolivian samples; Richard Ash, Igor Puchtel, Zhang Wen, and

765 Lin Lin for help with analytical work; Mike Spicuzza for oxygen isotope analysis; Mike Ream

766 and Will Junkin for help with sample processing; and Lew Ashwal and Sue Webb for providing

767 accommodations and libations in Johannesburg during our South African field work. We thank

768 Mark Fornace for his help in initially developing the standard addition method that we now use

769 in the Plasma Lab. We are especially grateful to Richard Ash for his endless support, insights,

770 and positive spirit in keeping the Plasma Lab operational. This paper was improved by detailed

771 and thoughtful reviews by Nick Arndt and Lang Farmer. 
773 Figure 1. Diamictite major element compositions (and sediments in general) are chiefly

774 controlled by the ratio of quartz to feldspars and clays/phyllosilicates, which forms the primary

775 trend. Departures from this trend are caused by unusually high levels of either $\mathrm{CaCO}_{3}$ or iron, as

776 seen in (b) and (c), which cause relative dilutions in the other major elements. The "carbonate

777 cut-off' line in (b) separates the carbonate-rich samples on the left from those used to calculate

778 the filtered medians in Figs. 13-14.

779 Figure 2. Rare earth element (REE) variations in diamictite composites ordered by depositional

780 age. Measured concentrations are double-normalized, with each analysis corrected for quartz

781 dilution by normalizing it to the average $\mathrm{UCC}_{\mathrm{RG}} \mathrm{Al}_{2} \mathrm{O}_{3}$ content and then normalizing individual

782 elements to chondrite (McDonough and Sun, 1995) in panel a, and average $\mathrm{UCC}_{\mathrm{RG}}$ in panel b.

783 Figure 3. Transition metals (a) and post-transition metals and metalloids (b) in diamictite

784 composites, double normalized to $\mathrm{UCC}_{\mathrm{RG}}$, as in Fig. 2.

785 Figure 4. Alkali and alkaline earth elements (a), high field strength elements (HFSE; b), and

786 actinides (c) in diamictite composites, double normalized to $\mathrm{UCC}_{\mathrm{RG}}$, as in Fig. 2.

787 Figure 5. (a) Whole-rock oxygen isotope compositions of individual diamictite samples versus

788 depositional age. Diamictites with LOI values greater than $7 \%$ were excluded in order to

789 eliminate the skewing effects of high carbonate content on $\delta^{18} \mathrm{O}$ (see supplemental material for

790 discussion). Large colored boxes are median values for each of the four time periods. The

791 median absolute error is shown as a vertical line for the Paleozoic but is smaller than the symbols

792 for the other three periods. Mantle composition is from Valley et al. (1998). Shaded field is

793 range of clastic sediment/sedimentary rock analyses compiled by Payne et al. (2015), filtered 
794 here to exclude samples metamorphosed at medium and high-grade conditions, with additional 795 data from Bindeman et al. (2016). Mesoarchean diamictites extend to distinctly lower $\delta^{18} \mathrm{O}$ 796 values compared to post-Archean diamictites. Although the other three glacial periods contain 797 outliers, the average values become progressively higher with time. (b) $\delta^{18} \mathrm{O}$ versus CIA

798 (chemical index of alteration, a measure of chemical weathering intensity). If $\delta^{18} \mathrm{O}$ values are 799 being controlled by chemical weathering, a positive correlation should be present in the data.

800 While this is true of the Neoproterozoic and Paleozoic diamictites, the $\delta^{18} \mathrm{O}$ and CIA values are 801 largely decoupled for the Mesoarchean and Paleoproterozoic diamictites.

802 Figure 6. Upper: Chemical index of alteration (CIA) versus index of chemical variability (ICV).

803 Lower: an expanded view of the dashed box in the upper panel. The ICV increases as the

804 composition becomes more mafic. See text for formal definitions. Average igneous

805 compositions shown as purple triangles are from Condie (1993) and tie lines to CIA=100 and

$806 \mathrm{ICV}=0$ are weathering trends. $\mathrm{UCC}_{\mathrm{RG}}$ is also shown as a purple triangle and plots with a primary

807 igneous CIA because it is largely derived from grid sampling studies of igneous basement.

808 Samples with $>7 \%$ LOI have been excluded, as their high carbonate content results in extreme

809 ICV values. Most diamictites fall along a weathering trend leading back to an andesitic

810 composition but many of the Mesoarchean and some of the Paleoproterozoic samples fall near tie

811 lines more consistent with a komatiitic source.

812 Figure 7. Ternary plots separating the effects of weathering from source rock composition, after

813 Ohta and Arai (2007). This approach is based on principal component analysis of the major

814 elements and divides compositions amongst "mafic" (M), "felsic" (F), and "weathered" (W) end-

815 members. Unweathered igneous rocks plot along the arc connecting the $\mathrm{M}$ and $\mathrm{F}$ apices whereas 816 weathering will draw compositions toward the $\mathrm{W}$ apex. Most diamictites plot in positions 
817 consistent with a weathered intermediate source composition but Mesoarchean samples clearly

818 derive from a more mafic source.

819 Figure 8. Trace element ratios sensitive to differentiation and/or mafic versus felsic sources

820 plotted against depositional age for the composites, which represent average compositions for

821 each diamictite unit. The decreasing (a) Ni/Lu, increasing (b) Th/Sc, and increasingly negative

822 Eu anomaly (c) are all consistent with a progressively less mafic, more differentiated UCC with

823 time. Large boxes and vertical bars represent median values and median absolute deviations for

824 all individual samples from each time period, with the exception of the western Dwyka samples,

825 which are dominated by $>2.0 \mathrm{Ga}$ sources (see text for discussion). In this and subsequent

826 figures, the $\mathrm{UCC}_{\mathrm{RG}}$ line represents the average UCC composition of Rudnick and Gao (2003)

827 and shaded area represents the range of other published UCC models (Shaw et al, 1967, 1976;

828 Eade and Fahrig, 1973; Taylor and McLennan, 1985; Condie, 1993; Wedepohl, 1995; Gao et al.,

829 1998; Kamber et al., 2005; Hu and Gao, 2008; Chauvel et al., 2014).

830 Figure 9. Changes in Th and $\mathrm{U}$ with time for diamictite composites. Th and $\mathrm{U}$ are divided by

$831 \mathrm{Al}$ (in ppm) in (a) and (b) to correct for quartz dilution effects. (a) Th shows a clear increase

832 between the Mesoarchean and Paleoproterozoic. (b) A clear trend with age is less clear for U,

833 but this is at least partially due to the effects of $U$ mobility during oxidative weathering. (c)

$834 \mathrm{Th} / \mathrm{U}$ shows a steady increase with time and is highly variable in the Neoproterozoic. Both the

835 increase and variability are likely driven by oxidative weathering, which became increasingly

836 important after the Paleoproterozoic glaciations. $\mathrm{UCC}_{\mathrm{RG}}$ and range of other UCC estimates are

837 shown as a solid line and shaded area, respectively, as in Figure 8.

838 Figure 10. Changes in REE fractionation (a, c, e) and normalized abundances (b, d, f) with time 839 for diamictite composites. (a, c, e) La/Lu represents the fractionation between the LREE and 
840 HREEs and shows a large range for the different periods but appears to decrease slightly with

841 time. La/Sm represents the fractionation within the LREEs and shows a significant decrease

842 with time. Gd/Lu represents the fractionation within the HREEs and does not vary time. The

843 changes seen in $\mathrm{La} / \mathrm{Lu}$ and $\mathrm{La} / \mathrm{Sm}$ may reflect a decrease in relative abundance of TTGs as a

844 percent of the UCC and the increase in abundance of potassic "true" granites. (b, d, f) La, Gd,

845 and Lu are given as representatives of the LREEs, MREEs, and HREEs, respectively. All

846 elements are divided by $\mathrm{Al}$ (in ppm) to correct of quartz dilution effects. Increases in abundance

847 are seen in all four elements with time and are especially marked for the MREEs and HREEs.

848 This likely reflects both the increasingly felsic and differentiated nature of the UCC with time

849 and the decrease in the relative proportion of TTGs to potassic granites, as the latter are more

850 enriched in MREEs and HREEs. $\mathrm{UCC}_{\mathrm{RG}}$ and range of other $\mathrm{UCC}$ estimates are shown as a solid

851 line and shaded area, respectively, as in Figure 8.

852 Figure 11. (a) Sm-Nd and (b) Lu-Hf ratios in diamictite composites versus age. Significant

853 overlap exists for all periods. Sm-Nd ratios are consistently higher than the Rudnick and Gao

854 (2003) UCC estimate but do not exceed the full range of values in the literature. UCC $_{\text {RG }}$ and

855 range of other UCC estimates are shown as a solid line and shaded area, respectively, as in

856 Figure 8.

857 Figure 12. HFSE ratios in diamictite composites versus age. (a) $\mathrm{Nb} / \mathrm{Ta}$ shows a prominent

858 increase between the Paleoproterozoic and Neoproterozoic, and (c) La/ $\mathrm{Nb}$ shows an analogous

859 decrease. This may reflect a decrease in the relative abundance of TTGs with time in the UCC.

$860 \mathrm{UCC}_{\mathrm{RG}}$ and range of other UCC estimates are shown as a solid line and shaded area,

861 respectively, as in Figure 8. 
862 Figure 13. (a) Comparison of major elements in versions of the diamictite-based UCC model,

863 normalized to the Rudnick and Gao (2003) UCC. The squares are derived from the median of all

864 individual Neoproterozoic and Paleozoic samples and the diamonds are based on the median of

865 individual samples to the right of the carbonate cut-off boundary in Fig. 1b. Error bars are

866 median absolute deviations. (b) Major elements from other UCC models, normalized to Rudnick

867 and Gao (2003). References: Shaw et al. (1967, 1976), Eade and Fahrig (1973), Condie (1993),

868 Taylor and McLennan (1985), Ronov and Yaroshevskiy (1967, 1976), and Borodin (1998).

869 Figure 14. Comparison of trace elements in the (a) two versions of the diamictite-based UCC

870 model, as in Fig. 13. (b) Other UCC models are also shown. References: Shaw et al. (1967,

871 1976), Eade and Fahrig (1973), Condie (1993), Gao et al. (1998), Kamber et al. (2005), Taylor

872 and McLennan (1985) including additional data from McLennan (2001), Wedepohl (1995), Hu

873 and Gao (2008), and Chauvel et al. (2014) incorporating the Li concentration from Sauzeat et al.

874 (2015).

875 Figure 15. Correlations seen amongst the chalcophile and siderophile trace elements and Be in 876 the diamictites.

878 References

880 Arndt, N. (1999) Why was flood volcanism on submerged continental platforms so common in 881 the Precambrian? Precambrian Research 97, 155-164. 
883 Arndt, N. (2013) The formation and evolution of the continental crust: Geochemical

884 Perspectives, 2, 405-533.

885

886 Barth, M.G., McDonough, W.F., Rudnick, R.L. (2000) Tracking the budget of Nb and Ta in the 887 continental crust. Chemical Geology 165, 197-213.

Bindeman, I.N., Bekker, A., Zakharov, D.O. (2016) Oxygen isotope perspective on crustal

890 evolution on early Earth: A record of Precambrian shales with emphasis on Paleoproterozoic

891 glaciations and Great Oxygenation Event. Earth and Planetary Science Letters 437, 101-113.

892

893 Borodin, L.S. (1998) Estimated chemical composition and petrochemical evolution of the upper 894 continental crust. Geochemistry International 37, 723-734.

895

896 Calvert S.E., Pedersen T.F. (1993) Geochemistry of Recent oxic and anoxic marine sediments:

897 Implications for the geological record. Marine Geology 113, 67-88.

898

899 Canil, D., Lacourse, T. (2011) An estimate for the bulk composition of juvenile upper

900 continental crust derived from glacial till in the North American Cordillera. Chemical Geology

$901 \quad 284,229-239$.

902

903 Carto, S.L., Eyles, N. (2011) The deep-marine glaciogenic Gaskiers Formation, Newfoundland, 904 Canada. In The Geological Record of Neoproterozoic Glaciations (eds. Arnaud, E., Halverson, 905 G.P., Shields-Zhou, G.), The Geological Society, London. pp. 467-473. 
907 Chauvel, C., Garcon, M., Bureau, S., Besnault, A., Jahn, B.-M., Ding, Z. (2014) Constraints from

908 loess on the Hf-Nd isotopic composition of the upper continental crust. Earth and Planetary

909 Science Letters 388, 48-58.

910

911 Clark, P.U. (1987) Subglacial sediment dispersal and till composition. The Journal of Geology

$91295,527-541$.

913

914 Collerson, K.D., Kamber, B.S. (1999) Evolution of the continents and the atmosphere inferred

915 from Th-U-Nb systematics of the depleted mantle. Science $\mathbf{2 8 3}, 1519-1522$.

916

917 Committee on Grand Research Questions in the Solid-Earth Sciences (2008) Origin and

918 Evolution of Earth: Research Questions for a Changing Planet, National Research Council, 152

919 p. ISBN: 978-0-309-11717-3.

920

921 Condie, K.C. (1993) Chemical composition and evolution of the upper continental crust:

922 Contrasting results from surface samples and shales. Chemical Geology 104, 1-37.

923

924 Condie K.C. (2005) TTGs and adakites: are they both slab melts? Lithos 80, 33-44.

925

926 Cox, R.N., Lowe, D.R., Cullers, R.L. (1995) The influence of sediment recycling and basement 927 composition on evolution of mudrock chemistry in the southwestern United States. Geochimica 928 et Cosmochimica Acta 59, 2919-2940.

929 
930 Drummond, M.S., Defant, M.J. (1990) A model for trondhjemite-tonalite-dacite genesis and 931 crustal growth via slab melting: Archean to modern comparisons. Journal of Geophysical 932 Research 95, 21503-21521.

933

934 Eade, K.E., Fahrig, W.F. (1973) Regional, lithological, and temporal variation in the abundances 935 of some trace elements in the Canadian Shield. Geological Survey of Canada Paper 72.

936 Eiler, J.M. (2001) Oxygen isotope variations of basaltic lavas and upper mantle rocks. Rev. in 937 Mineral. Geochem 43, 319-364.

939 Farmer, G.L., Licht, K., Swope, R.J. and Andrews, J. (2006) Isotopic constraints on the 940 provenance of fine-grained sediment in LGM tills from the Ross Embayment, Antarctica. Earth 941 and Planetary Science Letters 249, 90-107.

943 Fedo, C.M., Wayne Nesbitt, H. and Young, G.M. (1995) Unraveling the effects of potassium 944 metasomatism in sedimentary rocks and paleosols, with implications for paleoweathering 945 conditions and provenance. Geology 23, 921-924.

947 Frimmel, H.E. (2011) The Kaigas and Numees formations, Port Nolloth Group, in South Africa 948 and Namibia. In The Geological Record of Neoproterozoic Glaciations (eds. Arnaud, E., 949 Halverson, G.P., Shields-Zhou, G.). The Geological Society, London, pp. 223-231.

951 Gaillard, F., Scaillet, B., Arndt, N.T. (2011) Atmospheric oxygenation caused by a change in 952 volcanic degassing pressure. Nature 478, 229-232. 
954 Gao, S., Luo, T.-C., Zhang, B.-R., Zhang, H.-F., Han, Y.-w., Zhao, Z.-D., Hu, Y.-K. (1998)

955 Chemical composition of the continental crust as revealed by studies in East China. Geochimica 956 et Cosmochimica Acta 62, 1959-1975.

957

958 Gaschnig, R.M., Rudnick, R.L., McDonough, W.F. (2015) Determination of Ga, Ge, Mo, Ag, $959 \mathrm{Cd}, \mathrm{In}, \mathrm{Sn}, \mathrm{Sb}, \mathrm{W}, \mathrm{Tl}$, and Bi in USGS whole-rock reference materials by standard addition ICP960 MS. Geostandards and Geoanalytical Research 39, 371-379.

961

962 Gaschnig, R.M., Rudnick, R.L., McDonough, W.F., Kaufman, A.J., Vervoort, J.D., Fisher, C.

963 (2015) Insights into crustal growth from detrital zircons in ancient glacial deposits: EOS,

964 Transactions, American Geophysical Union.

965

966 Gaschnig, R.M., Rudnick, R.L., McDonough, W.F., Kaufman, A.J., Hu, Z., Gao, S. (2014) Onset

967 of oxidative weathering of continents recorded in the geochemistry of ancient glacial diamictites.

968 Earth and Planetary Science Letters 408, 87-99.

969

970 Goldschmidt VM (1933) Grundlagen der quantitativen geochemie. Fortschritte der Mineralogie,

$971 \quad$ Krystallographie und Petrographie 17:112

972

973 Goldschmidt, V. M. (1958) Geochemistry. Oxford University Press, Oxford.

974

975 Green, T.H. (1995) Significance of $\mathrm{Nb} / \mathrm{Ta}$ as an indicator of geochemical processes in the crust976 mantle system. Chemical Geology 120, 347-359. 
978 Grimes CB, Ushikubo T, John BE, Valley JW (2011) Uniformly mantle-like $\delta^{18}$ O in zircons

979 from oceanic plagiogranites and gabbros, Contr. Min. Pet. 161, 13-33.

980

981 Hambrey, M.J., Harland, W.B., eds., (1981) Earth's Pre-Pleistocene Glacial Record. Cambridge 982 University Press, Cambridge.

983

984 Hildes, D.H.D., Clarke, G.K.C., Flowers, G.E. and Marshall, S.J. (2004) Subglacial erosion and 985 englacial sediment transport modelled for North American ice sheets. Quaternary Science 986 Reviews 23, 409-430.

987 Hoffman, P.F. (2011) Strange bedfellows; glacial diamictite and cap carbonate from the 988 Marinoan (635 Ma) glaciation in Namibia. Sedimentology 58, 57-119.

989

990 Hoffmann, J.E., Münker, C., Næraa, T., Rosing, M.T., Herwartz, D., Garbe-Schönberg, D., 991 Svahnberg, H. (2011) Mechanisms of Archean crust formation inferred from high-precision 992 HFSE systematics in TTGs. Geochimica et Cosmochimica Acta 75, 4157-4178.

993

994 Hofmann, M., Linnemann, U., Hoffmann, K.-H., Germs, G., Gerdes, A., Marko, L., Eckelmann, 995 K., Gärtner, A. and Krause, R. (2015) The four Neoproterozoic glaciations of southern Namibia 996 and their detrital zircon record: The fingerprints of four crustal growth events during two 997 supercontinent cycles. Precambrian Research 259, 176-188.

998 
999 Holland, H.D. (2006) The oxygenation of the atmosphere and oceans. Philosophical

1000 Transactions of the Royal Society B: Biological Sciences 361, 903-915.

1001

1002 Houston, R.S., Karlstrom, K.E., Graff, P.J., Flurkey, A.J. (1992) New stratigraphic subdivisions

1003 and redefinition of subdivisions of Late Archean and Early Proterozoic metasedimentary and

1004 metavolcanic rocks of the Sierra Madre and Medicine Bow Mountains, southern Wyoming. U.S.

1005 Geological Survey Professional Paper 1520.

1006

1007 Jochum, K.P., Hofmann, A.W., Seufert, H.M. (1993) Tin in mantle-derived rocks: Constraints on 1008 Earth evolution. Geochimica et Cosmochimica Acta 57, 3585-3595.

1009

1010 Kamber, B.S., Greig, A., Collerson, K.D. (2005) A new estimate for the composition of

1011 weathered young upper continental crust from alluvial sediments, Queensland, Australia.

1012 Geochimica et Cosmochimica Acta 69, 1041-1058.

1013

1014 Kaufman, A.J., Sial, A.N., Frimmel, H.E., Misi, A. (2009) Neoproterozoic to Cambrian

1015 Palaeoclimatic Events in Southwestern Gondwana. In Neoproterozoic-Cambrian tectonics,

1016 global change and evolution: a focus on southwestern Gondwana (eds. Gaucher, C., Sial, A.N.,

1017 Halverson, G.P., Frimmel, H.E.). Elsevier, Amsterdam. pp. 369-388.

1018

1019 Keeley, J.A., Link, P.K., Fanning, C.M., Schmitz, M.D. (2013) Pre- to synglacial rift-related

1020 volcanism in the Neoproterozoic (Cryogenian) Pocatello Formation, SE Idaho: New SHRIMP

1021 and CA-ID-TIMS constraints. Lithosphere 5, 128-150. 
1023 Keller, C.B., Schoene, B. (2012) Statistical geochemistry reveals disruption in secular 1024 lithospheric evolution about 2.5 Gyr ago. Nature 485, 490-493.

1025

1026 Klassen, R.A. (1999) The application of glacial dispersal models to the interpretation of till 1027 geochemistry in Labrador, Canada. Journal of Geochemical Exploration 67, 245-269.

1029 Knauth, L.P., Lowe, D.R. (2003) High Archean climatic temperature inferred from oxygen 1030 isotope geochemistry of cherts in the 3.5 Ga Swaziland Supergroup, South Africa. Geological 1031 Society of America Bulletin 115, 566-580.

1032

1033 Le Heron, D.P., Busfield, M.E., Kamona, F. (2013) An interglacial on snowball Earth? Dynamic 1034 ice behaviour revealed in the Chuos Formation, Namibia. Sedimentology 60, 411-427.

1035

1036 Li, S., Gaschnig, R.M., Rudnick, R.L. (2016) Insights into chemical weathering of the upper 1037 continental crust from the geochemistry of ancient glacial diamictites: Geochimica et 1038 Cosmochimica Acta 176, 96-117.

1039

1040 Liu, C.-Q., Masuda, A., Okada, A., Yabuki, S., Zhang, J., Fan, Z.-L. (1993) A geochemical study

1041 of loess and desert sand in northern China: Implications for continental crust weathering and 1042 composition. Chemical Geology 106, 359-374.

1043 
1044 Liu, X., Gao, S., Diwu, C., Ling, W. (2008) Precambrian crustal growth of Yangtze Craton as

1045 revealed by detrital zircon studies. American Journal of Science 308, 421-468.

1046

1047 Marschall, H.R., Dohmen, R. and Ludwig, T. (2013) Diffusion-induced fractionation of niobium 1048 and tantalum during continental crust formation. Earth and Planetary Science Letters 375, 3611049371.

1050

1051 Mattey, D., Lowry, D., Macpherson, C. (1994) Oxygen isotope composition of mantle peridotite.

1052 Earth and Planetary Science Letters 128, 231-241.

1053

1054 McDonough, W.F. (1990) Constraints on the composition of the continental lithospheric mantle. 1055 Earth and Planetary Science Letters 101, 1-18.

1056

1057 McLennan, S.M. (1993) Weathering and global denudation. The Journal of Geology 101, 2951058303.

1059

1060 McLennan, S.M. (2001) Relationships between the trace element composition of sedimentary 1061 rocks and upper continental crust. Geochem. Geophys. Geosyst. 2, 1021.

1062

1063 McLennan, S.M., Fryer, B.J., Young, G.M. (1979) Rare earth elements in Huronian (Lower 1064 Proterozoic) sedimentary rocks: Composition and evolution of the post-Kenoran upper crust. 1065 Geochimica et Cosmochimica Acta 43, 375-388. 
1067 McLennan, S.M., Nance, W.B., Taylor, S.R. (1980) Rare earth element-thorium correlations in 1068 sedimentary rocks, and the composition of the continental crust. Geochimica et Cosmochimica 1069 Acta 44, 1833-1839.

1070

1071 McLennan, S.M., Taylor, S.R. (1980) Th and U in sedimentary rocks: crustal evolution and 1072 sedimentary recycling. Nature 285, 621-624.

1073

1074 McLennan, S.M., Taylor, S.R., Kroner, A. (1983) Geochemical evolution of Archean shales 1075 from South Africa. I. The Swaziland and Pongola Supergroups. Precambrian Research 22, 931076124.

1077

1078 Melezhik, V.A., Young, G.M., Eriksson, P.G., Altermann, W., Kump, L.R., Lepland, A., (2013)

1079 Huronian-age glaciation. In Global Events and the Fennoscandian Arctic Russia - Drilling Earth

1080 Earth Project (eds. Melezhik, V.A., Prave, A.R., Hanski, E.J., Fallick, A.E., Lepland, A., Kump,

1081 L.R., Strauss, H.). Springer-Verlag, Berlin. pp. 1059-1109.

1082

1083 Moyen, J., Martin, H. (2012) Forty years of TTG research. Lithos 148, 312-336.

1084

1085 Muehlenbachs, K. (1998) The oxygen isotopic composition of the oceans, sediments and the 1086 seafloor. Chemical Geology 145, 263-273.

1087

1088 Nance, W.B., Taylor, S.R. (1976) Rare earth element patterns and crustal evolution - I.

1089 Australian post-Archean sedimentary rocks. Geochimica et Cosmochimica Acta 40, 1539-1551. 
1091 Nance, W.B., Taylor, S.R. (1977) Rare earth element patterns and crustal evolution - II. Archean

1092 sedimentary rocks from Kalgoorlie, Australia. Geochimica et Cosmochimica Acta 41, 225-231.

1093

1094 Nesbitt, H.W., Young, G.M. (1982) Early Proterozoic climates and plate motions inferred from 1095 major element chemistry of lutites. Nature 299, 715-717.

1096

1097 Ohta, T., Arai, H. (2007) Statistical empirical index of chemical weathering in igneous rocks: A 1098 new tool for evaluating the degree of weathering. Chemical Geology 240, 280-297.

1099

1100 Payne, J.L., Hand, M., Pearson, N.J., Barovich, K.M., McInerney, D.J. (2015) Crustal thickening

1101 and clay: Controls on $\mathrm{O}$ isotope variation in global magmatism and siliciclastic sedimentary

1102 rocks. Earth and Planetary Science Letters 412, 70-76.

1103

1104 Pearce, J.A. and Peate, D.W. (1995) Tectonic implications of the composition of volcanic arc

1105 magmas. Annual Review of Earth and Planetary Sciences 23, 251-285.

1106

1107 Peucker-Ehrenbrink, B., Jahn, B.-M. (2001) Rhenium-osmium isotope systematics and platinum 1108 group element concentrations: Loess and the upper continental crust. Geochem. Geophys.

1109 Geosyst. 2. 2001GC000172.

1110

1111 Potter, P.E., Maynard, J.B., Depetris, P.J. (2005) Mud and Mudstones: Introduction and

1112 Overview. Springer-Verlag, Hiedelberg, 297 p. 
1114 Pfander, J.A., Munker, C., Stracke, A., Mezger, K. (2007) Nb/Ta and Zr/Hf in ocean island

1115 basalts -- Implications for crust-mantle differentiation and the fate of Niobium. Earth and

1116 Planetary Science Letters 254, 158-172.

1118 Prave, A.R., Hoffmann, K.H., Hegenberger, W., Fallick, A.E. (2011) The Witvlei Group of east1119 central Namibia. In The Geological Record of Neoproterozoic Glaciations (eds. Arnaud, E., 1120 Halverson, G.P., Shields-Zhou, G.). The Geological Society, London. pp. 211-216.

1122 Rankin, D.W. (1993) The volcanogenic Mount Rogers Formation and the overlying glaciogenic 1123 Konnarock Formation; two late Proterozoic units in southwestern Virginia. U.S. Geological 1124 Survey Bulletin 2029.

1126 Rey, P.F. and Coltice, N. (2008) Neoarchean lithospheric strengthening and the coupling of 1127 Earth's geochemical reservoirs. Geology 36, 635-638.

1129 Ronov, A.B., Yaroshevsky, A.A. (1967) Chemical structure of the Earth's crust. Geokhimiya 11, $1130 \quad$ 1285-1309.

1132 Ronov, A.B., Yaroshevsky, A.A. (1976) A new model for the chemical structure of the Earth's 1133 crust. Geokhimiya 12, 1761-1795. 
1135 Rudnick, R.L., Barth, M., Horn, I., McDonough, W.F. (2000) Rutile-bearing refractory eclogites:

1136 missing link between continents and depleted mantle. Science 287, 278-281.

1139 Rudnick, R.L., Gao, S. (2003) The composition of the continental crust, in: Rudnick, R.L. (Ed.), 1140 The Crust. Elsevier-Pergamon, Oxford, pp. 1-64.

1142 Ryan, J.G., 2002. Trace-element systematics of beryllium in terrestrial materials. Rev. in 1143 Mineral. Geochem 50, 121-146.

1145 Sauzéat, L., Rudnick, R.L., Chauvel, C., Garçon, M., Tang, M. (2015) New perspectives on the $1146 \mathrm{Li}$ isotopic composition of the upper continental crust and its weathering signature. Earth and 1147 Planetary Science Letters 428, 181-192.

1149 Shaw, D.M., Dostal, J., Keays, R.R. (1976) Additional estimates of continental surface

1150 Precambrian shield composition in Canada. Geochimica et Cosmochimica Acta 40, 73-83.

1152 Shaw, D.M., Reilly, G.A., Muysson, J.R., Pattenden, G.E., Campbell, F.E. (1967) An estimate of 1153 the chemical composition of the Canadian Precambrian Shield. Canadian Journal of Earth 1154 Sciences 4, 829-853. 
1156 Spicuzza, M.J., Valley, J.W., McConnell, V.S. (1998) Oxygen isotope analysis of whole rock via

1157 laser fluorination: an air-lock approach. Abstracts with Programs - Geological Society of

1158 America 30, 80.

1159

1160 Starck, D., Papa, C.d. (2006) The northwestern Argentina Tarija Basin: Stratigraphy,

1161 depositional systems, and controlling factors in a glaciated basin. Journal of South American

1162 Earth Sciences 22, 169-184.

1163

1164 Tang, M., Chen, K., Rudnick, R.L. (2016) Archean upper crust transition from mafic to felsic

1165 marks the onset of plate tectonics. Science 351, 372-375.

1166

1167 Tang, M., Rudnick, R. L., McDonough, W. F., Gaschnig, R. M., and Huang, Y. (2015) Europium

1168 anomalies constrain the mass of recycled lower continental crust: Geology 43, 703-706.

1169

1170 Taylor, S.R., McLennan, S.M., McCulloch, M.T. (1983) Geochemistry of loess, continental

1171 crustal composition and crustal model ages. Geochimica et Cosmochimica Acta 47, 1897-1905.

1172

1173 Taylor, S.R., McLennan, S.M. (1985) The Continental Crust: It's Composition and Evolution.

1174 Blackwell Scientific, Oxford, 312 p.

1175

1176 Taylor, S.R., McLennan, S.M. (1995) The geochemical evolution of the continental crust.

1177 Reviews of Geophysics 33, 241-265.

1178 
1179 Togashi, S., Imai, N., Okuyama-Kusunose, Y., Tanaka, T., Okai, T., Koma, T., Murata, Y.

1180 (2000) Young upper crustal chemical composition of the orogenic Japan Arc. Geochemistry,

1181 Geophysics, and Geosystems 1, 1049.

1182

1183 Valley, J.W., Kitchen, N., Kohn, M.J., Niendorf, C.R., Spicuzza, M.J. (1995) UWG-2, a garnet

1184 standard for oxygen isotope ratios: Strategies for high precision and accuracy with laser heating.

1185 Geochimica et Cosmochimica Acta 59, 5223-5231.

1186

1187 Valley, J. W., Kinny, P. D., Schulze, D. J., and Spicuzza, M. J. (1998) Zircon Megacrysts from

1188 Kimberlite: Oxygen isotope heterogeneity among mantle melts. Contributions to Mineralogy

1189 and Petrology 133, 1-11.

1190

1191 Valley, J.W., Lackey, J.S., Cavosie, A.J., Clechenko, C.C., Spicuzza, M.J., Basei, M.A.S.,

1192 Bindeman, I.N., Ferreira, V.P., Sial, A.N., King, E.M., Peck, W.H., Sinha, A.K., Wei, C.S.

1193 (2005) 4.4 billion years of crustal maturation: oxygen isotope ratios of magmatic zircon.

1194 Contributions to Mineralogy and Petrology 150, 561-580.

1195

1196 Visser, J.N.J. (1982) Upper Carboniferous glacial sedimentation in the Karoo Basin near Prieska,

1197 South Africa. Palaeogeography, Palaeoclimatology, Palaeoecology 38, 63-92.

1198

1199 Vorster, C. (2013) Laser ablation ICP-MS age determination of detrital zircon populations in the

1200 Phanerozoic Cape and lower Karoo Supergroup (South Africa) and correlatives in Argentina.

1201 Ph.D. thesis, University of Johannesburg. 
1203 Wedepohl, K.H. (1995) The composition of the continental crust. Geochimica et Cosmochimica 1204 Acta 59, 1217-1232.

1206 Whalen, J.B., Percival, J.A., McNicoll, V.J., Longstaffe, F.J. (2004) Geochemical and isotopic 1207 (Nd-O) evidence bearing on the origin of late- to post-orogenic high-K granitoid rocks in the 1208 Western Superior Province: implications for late Archean tectonomagmatic processes.

1209 Precambrian Research 132, 303-326.

1210

1211 Wronkiewicz, D.J., Condie, K.C. (1987) Geochemistry of Archean shales from the

1212 Witwatersrand Supergroup, South Africa: Source-area weathering and provenance. Geochimica 1213 et Cosmochimica Acta 51, 2401-2416.

1214

1215 Wronkiewicz, D.J., Condie, K.C. (1989) Geochemistry and provenance of sediments from the 1216 Pongola Supergroup, South Africa: Evidence for a 3.0-Ga-old continental craton. Geochimica et 1217 Cosmochimica Acta 53, 1537-1549.

1219 Wronkiewicz, D.J., Condie, K.C. (1990) Geochemistry and mineralogy of sediments from the 1220 Ventersdorp and Transvaal Supergroups, South Africa: Cratonic evolution during the early 1221 Proterozoic. Geochimica et Cosmochimica Acta 54, 343-354.

1223 Yonkee, W.A., Dehler, C.D., Link, P.K., Balgord, E.A., Keeley, J.A., Hayes, D.S., Wells, M.L., 1224 Fanning, C.M., Johnston, S.M. (2014) Tectono-stratigraphic framework of Neoproterozoic to 
1225 Cambrian strata, west-central U.S.: Protracted rifting, glaciation, and evolution of the North 1226 American Cordilleran margin. Earth-Science Reviews 136, 59-95.

1228 Young, G.M., Minter, W.E.L., Theron, J.N. (2004) Geochemistry and palaeogeography of upper 1229 Ordovician glaciogenic sedimentary rocks in the Table Mountain Group, South Africa.

1230 Palaeogeography, Palaeoclimatology, Palaeoecology 214, 323-345.

1231

1232 Young, G.M., von Brunn, V., Gold, D.J.C., Minter, W.E.L. (1998) Earth's oldest reported

1233 glaciation: physical and chemical evidence from the Archean Mozaan Group ( 2.9 Ga) of South 1234 Africa. Journal of Geology 106, 523-538.

1235

1236 Zhang, W., Hu, Z., Liu, Y., Chen, H., Gao, S., Gaschnig, R.M. (2012a) Total Rock Dissolution 1237 Using Ammonium Bifluoride $\left(\mathrm{NH}_{4} \mathrm{HF}_{2}\right)$ in Screw-Top Teflon Vials: A New Development in 1238 Open-Vessel Digestion. Analytical Chemistry 84, 10686-10693.

1240 Zhang, W., Hu, Z., Liu, Y., Chen, L., Chen, H., Li, M., Zhao, L., Hu, S., Gao, S. (2012b)

1241 Reassessment of $\mathrm{HF} / \mathrm{HNO}_{3}$ decomposition capability in the high-pressure digestion of felsic 1242 rocks for multi-element determination by ICP-MS. Geostandards and Geoanalytical Research 1243 36, 271-289.

1245 Zhou, C., Tucker, R., Xiao, S., Peng, Z., Yuan, X., Chen, Z. (2004) New constraints on the ages 1246 of Neoproterozoic glaciations in south China. Geology 32, 437-440. 
Table 1. Glacial diamictites investigated in this study.

\begin{tabular}{|c|c|c|c|c|}
\hline Stratigraphic unit & $\begin{array}{l}\text { Country } \\
\text { (state/province) }\end{array}$ & $\begin{array}{l}\text { Drill core or } \\
\text { Outcrop? }\end{array}$ & General reference & $\begin{array}{l}\text { Approximat } \\
\text { e Age (Ga) }\end{array}$ \\
\hline \multicolumn{5}{|l|}{ Archean } \\
\hline Mozaan Grp & S Africa & $\mathrm{O}$ & Young et al. (1998) & 2.9 \\
\hline Afrikander Frm* & S Africa & 0 & Guy et al. (2010) & 2.9 \\
\hline Coronation Frm* & S Africa & DC & Guy et al. (2010) & 2.9 \\
\hline Promise Frm* & S Africa & DC & Guy et al. (2010) & 2.9 \\
\hline \multicolumn{5}{|l|}{ Paleoproterozoic } \\
\hline Duitschland Frm & S Africa & DC & Melezhik et al. (2013) & 2.4 \\
\hline Timeball Hill Frm** & S Africa & DC & Melezhik et al. (2013) & 2.2 \\
\hline Makganyene Frm & S Africa & DC & Melezhik et al. (2013) & 2.3 \\
\hline Ramsay Lake Frm & Canada (Ontario) & $\mathrm{O}$ & Melezhik et al. (2013) & 2.4 \\
\hline Pecors Frm & Canada (Ontario) & $\mathrm{O}$ & Melezhik et al. (2013) & 2.4 \\
\hline Bruce Frm & Canada (Ontario) & $\mathrm{O}$ & Melezhik et al. (2013) & 2.4 \\
\hline Gowganda Frm & Canada (Ontario) & 0 & Melezhik et al. (2013) & 2.4 \\
\hline Bottle Creek Frm & USA (Wyoming) & $\mathrm{O}$ & Houston et al (1992) & 2.4 \\
\hline \multicolumn{5}{|l|}{ Neoproterozoic } \\
\hline Pocatello Frm & USA (Idaho) & $\mathrm{O}$ & Keeley et al (2013) & 0.7 \\
\hline Konnarock Frm & $\begin{array}{l}\text { USA (Virginia) } \\
\text { Canada }\end{array}$ & $\mathrm{O}$ & Rankin (1993) & 0.7 \\
\hline Gaskiers Frm & (Newfoundland) & $\mathrm{O}$ & Carto and Eyles (2011) & 0.58 \\
\hline Nantuo Frm & China (Hubei) & 0 & Zhou et al. (2004) & 0.64 \\
\hline Gucheng Frm & China (Hubei) & 0 & Liu et al (2008) & 0.7 \\
\hline Blaubeker Frm & Namibia & 0 & Prave et al. (2011) & 0.7 \\
\hline Kaigas Frm & Namibia & 0 & Frimmel (2011) & 0.75 \\
\hline Blasskranz & Namibia & 0 & Kaufman et al. (2010) & 0.64 \\
\hline Chuos Frm & Namibia & 0 & Le Heron et al. (2013) & 0.7 \\
\hline Numees Frm & Namibia & 0 & Frimmel (2011) & 0.6 \\
\hline Ghaub Frm & Namibia & 0 & Hoffman (2011) & 0.64 \\
\hline \multicolumn{5}{|l|}{ Paleozoic } \\
\hline Machareti Group & Bolivia & 0 & Starck and Papa (2006) & 0.3 \\
\hline Mandiyuti Group & Bolivia & 0 & Starck and Papa (2006) & 0.3 \\
\hline Pakhuis Frm & $\begin{array}{l}\text { S Africa } \\
\text { S Africa and }\end{array}$ & DC & Young et al. (2004) & 0.44 \\
\hline Dwyka Group & Namibia & $O \& D C$ & Visser (1982) & 0.3 \\
\hline \multicolumn{5}{|c|}{$\begin{array}{l}\text { O = outcrop, DC = drlll core } \\
*-\text { The Afrikander, Coronation, and Promise Formations are components of the Witwatersrand } \\
\text { Supergroup and are grouped as such in figures. Note that the Afrikander diamictite is sometimes } \\
\text { referred to as the Lagerspoort or the Blue Grit diamictite in the literature. }\end{array}$} \\
\hline
\end{tabular}




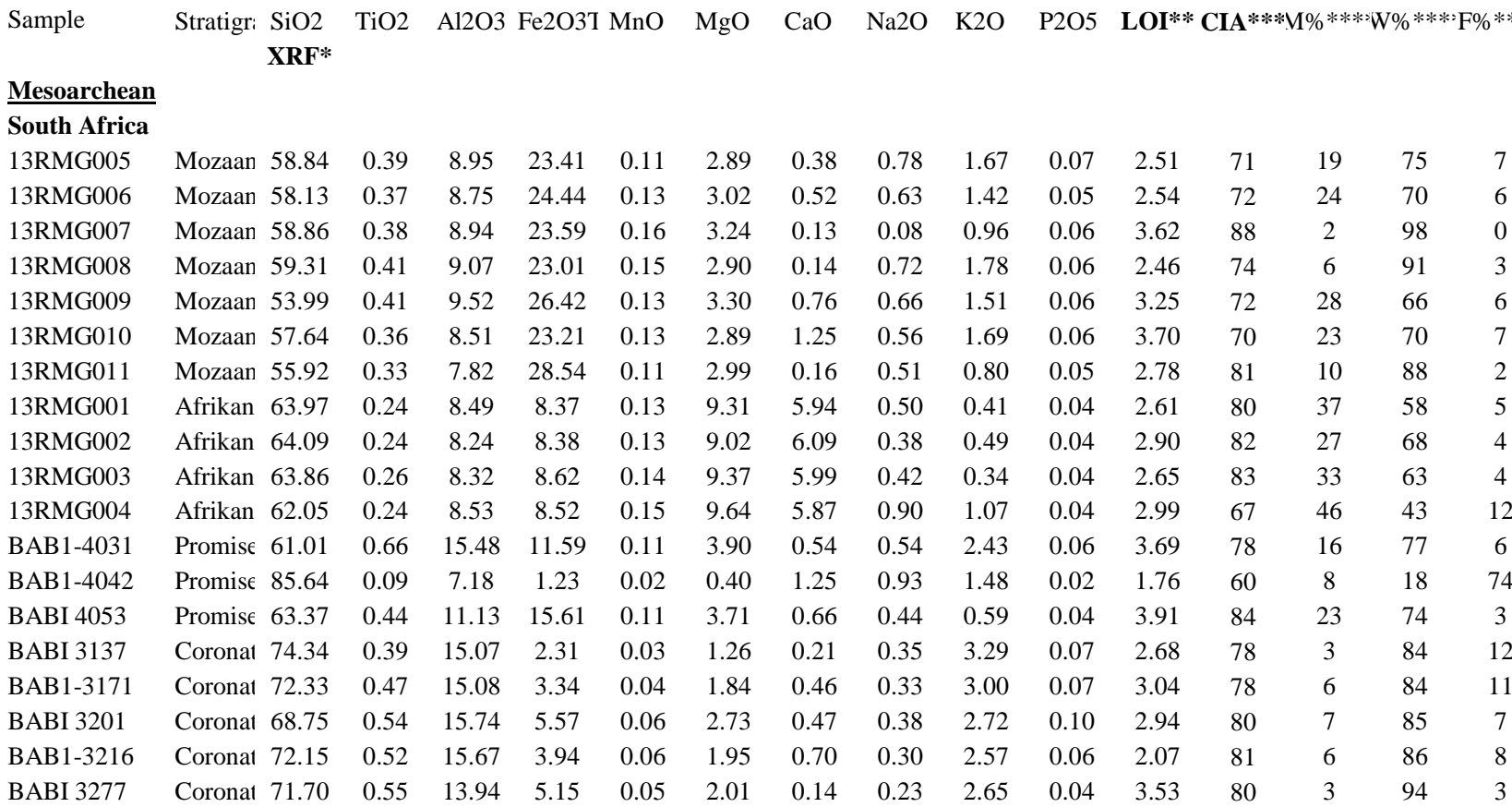

Paleoproterozoic

Wyoming

12RMG032

12RMG033

12RMG034

12RMG035

Bottle ( 72.19

$\begin{array}{lllll}\text { Bottle } C & 71.66 & 0.47 & 13.42 & 4.50\end{array}$

Bottle C 70.90

\section{Ontario}

\begin{tabular}{|c|c|c|c|c|c|c|c|c|c|c|c|c|c|c|c|c|}
\hline 12RMG036 & Ramsay & 82.09 & 0.26 & 7.91 & 2.84 & 0.06 & 0.98 & 1.29 & 1.86 & 1.60 & 0.05 & 1.07 & 53 & 23 & 23 & 54 \\
\hline 12RMG037 & Ramsay & 77.60 & 0.38 & 10.81 & 3.01 & 0.05 & 2.23 & 0.15 & 0.16 & 4.06 & 0.07 & 1.48 & 69 & 2 & 94 & 4 \\
\hline 12RMG040 & Gowgar & 69.30 & 0.47 & 13.83 & 5.84 & 0.03 & 2.17 & 0.34 & 5.08 & 1.40 & 0.11 & 1.43 & 57 & 18 & 50 & 32 \\
\hline 12RMG041 & Gowgar & 70.49 & 0.44 & 13.77 & 4.77 & 0.06 & 2.21 & 0.26 & 4.13 & 2.21 & 0.08 & 1.59 & 59 & 12 & 53 & 34 \\
\hline 12RMG042 & Bruce F & 71.27 & 0.41 & 14.12 & 2.87 & 0.02 & 2.19 & 0.35 & 4.23 & 2.90 & 0.10 & 1.54 & 57 & 11 & 40 & 48 \\
\hline 12RMG043 & Bruce $F$ & 62.28 & 0.61 & 17.37 & 5.16 & 0.04 & 3.81 & 0.41 & 3.60 & 3.84 & 0.12 & 2.76 & 62 & 15 & 54 & 31 \\
\hline 12RMG044 & Bruce F & 70.47 & 0.40 & 12.96 & 5.02 & 0.03 & 3.54 & 0.32 & 3.51 & 1.46 & 0.09 & 2.20 & 63 & 19 & 53 & 28 \\
\hline 12RMG050 & Ramsay & 61.19 & 0.72 & 15.82 & 9.93 & 0.10 & 4.19 & 0.53 & 2.31 & 1.86 & 0.18 & 3.17 & 71 & 22 & 64 & 13 \\
\hline 12RMG051 & Ramsay & 62.61 & 0.63 & 12.87 & 9.77 & 0.15 & 3.96 & 2.51 & 1.43 & 1.38 & 0.18 & 4.50 & 68 & 44 & 43 & 13 \\
\hline 12RMG052 & Ramsay & 59.20 & 0.89 & 15.02 & 12.15 & 0.14 & 4.74 & 0.71 & 1.41 & 1.55 & 0.18 & 4.02 & 76 & 28 & 63 & 8 \\
\hline 12RMG053 & Gowgar & 65.47 & 0.56 & 14.86 & 6.78 & 0.06 & 3.03 & 0.45 & 4.52 & 2.07 & 0.16 & 2.05 & 59 & 20 & 51 & 29 \\
\hline 12RMG054 & Gowgar & 65.32 & 0.59 & 15.07 & 6.49 & 0.05 & 2.95 & 0.48 & 4.80 & 2.17 & 0.16 & 1.92 & 58 & 21 & 49 & 31 \\
\hline 12RMG055 & Gowgar & 70.18 & 0.44 & 13.59 & 4.77 & 0.05 & 1.98 & 0.37 & 4.96 & 2.06 & 0.09 & 1.52 & 56 & 17 & 42 & 42 \\
\hline 12RMG056 & Gowgar & 66.70 & 0.54 & 14.16 & 6.93 & 0.05 & 2.86 & 0.27 & 4.64 & 1.66 & 0.11 & 2.08 & 59 & 16 & 60 & 24 \\
\hline 12RMG057 & Gowgar & 65.18 & 0.67 & 15.24 & 5.62 & 0.11 & 2.52 & 1.16 & 5.62 & 2.27 & 0.13 & 1.48 & 53 & 34 & 26 & 40 \\
\hline 12RMG058 & Gowgar & 64.71 & 0.72 & 15.32 & 5.70 & 0.14 & 2.60 & 1.15 & 5.67 & 2.39 & 0.11 & 1.50 & 53 & 34 & 27 & 39 \\
\hline 12RMG059 & Gowgar & 71.80 & 0.40 & 13.53 & 3.16 & 0.07 & 1.22 & 0.72 & 4.98 & 3.14 & 0.08 & 0.91 & 52 & 14 & 23 & 63 \\
\hline 12RMG063 & Gowgar & 65.20 & 0.56 & 14.67 & 7.37 & 0.06 & 2.58 & 0.71 & 4.75 & 2.20 & 0.14 & 1.76 & 57 & 27 & 39 & 34 \\
\hline 12RMG064 & Gowgar & 66.72 & 0.54 & 14.49 & 6.59 & 0.06 & 2.67 & 0.68 & 5.34 & 0.91 & 0.13 & 1.89 & 58 & 36 & 36 & 28 \\
\hline 12RMG065 & Gowgar & 74.13 & 0.35 & 10.96 & 3.06 & 0.04 & 2.06 & 1.13 & 2.52 & 3.83 & 0.14 & 1.79 & 52 & 19 & 26 & 55 \\
\hline 12RMG066 & Gowgar & 66.71 & 0.59 & 12.60 & 6.87 & 0.11 & 3.21 & 3.16 & 3.90 & 1.24 & 0.10 & 1.51 & 49 & 59 & 16 & 25 \\
\hline 12RMG067 & Gowgar & 66.89 & 0.57 & 12.48 & 5.85 & 0.11 & 3.63 & 2.14 & 2.31 & 1.56 & 0.10 & 4.37 & 58 & 50 & 26 & 24 \\
\hline 12RMG048 & Pecors I & 59.15 & 0.75 & 16.80 & 9.59 & 0.11 & 3.57 & 1.74 & 1.42 & 2.84 & 0.18 & 3.85 & 69 & 34 & 49 & 17 \\
\hline 12RMG049 & Pecors I & 56.55 & 0.90 & 21.05 & 8.25 & 0.07 & 2.89 & 0.18 & 0.99 & 5.01 & 0.13 & 3.98 & 75 & 0 & 98 & 2 \\
\hline
\end{tabular}

South Africa

GTF01.25

$\begin{array}{lllllllllllllll}\text { Makgar } & 50.93 & 0.36 & 7.04 & 18.17 & 0.65 & 5.33 & 6.50 & 0.06 & 0.54 & 0.09 & 10.33 & 92 & 1 & 99\end{array}$ 


\begin{tabular}{|c|c|c|c|c|c|c|c|}
\hline & $\begin{array}{c}\text { Average } \\
(n=7)^{*}\end{array}$ & $1 \mathrm{std}$ & $\%$ RSD & GEOREM & Average/GEOREM & $\begin{array}{l}\text { Std add } \\
\text { value }{ }^{* *} \\
\quad(n=6)\end{array}$ & $\begin{array}{c}\text { Std } \\
\text { add } \\
\text { \%RSD }\end{array}$ \\
\hline Li & 11.5 & 0.3 & 3.0 & 11 & 1.05 & & \\
\hline $\mathrm{Be}$ & 2.28 & 0.09 & 4.0 & 2.3 & 0.99 & & \\
\hline Sc & 12.6 & 1.6 & 12.9 & 13 & 0.97 & & \\
\hline V & 122 & 7 & 6.0 & 120 & 1.02 & & \\
\hline $\mathrm{Cr}$ & 15.5 & 0.5 & 2.9 & 17 & 0.91 & & \\
\hline Co & 15.2 & 0.3 & 1.8 & 16 & 0.95 & & \\
\hline $\mathrm{Ni}$ & 19.1 & 0.4 & 2.0 & 19 & 1.00 & & \\
\hline $\mathrm{Cu}$ & 52.8 & 1.4 & 2.6 & 53 & 1.00 & & \\
\hline Ga & 20.4 & 0.3 & 1.5 & 20 & 1.02 & 20.2 & 2.0 \\
\hline $\mathrm{Ge}$ & 1.22 & 0.043 & 3.5 & 1.43 & 0.86 & 1.15 & 3.4 \\
\hline $\mathrm{Rb}$ & 66.2 & 0.5 & 0.8 & 66.3 & 1.00 & & \\
\hline Sr & 649 & 5 & 0.7 & 661 & 0.98 & & \\
\hline Y & 20.2 & 0.2 & 1.1 & 20 & 1.01 & & \\
\hline $\mathrm{Zr}$ & 230 & 17 & 7.2 & 240 & 0.96 & & \\
\hline $\mathrm{Nb}$ & 13.8 & 0.2 & 1.4 & 14.6 & 0.95 & & \\
\hline Mo & 2.21 & 0.25 & 11.2 & 2.08 & 1.06 & 1.93 & 2.4 \\
\hline $\mathrm{Cd}^{* * *}$ & & & & 0.0820 & & 0.137 & 3.6 \\
\hline $\ln * * *$ & & & & 0.0480 & & 0.0445 & 2.0 \\
\hline Sn & 2.14 & 0.45 & 21.1 & 2.08 & 1.03 & 1.90 & 3.2 \\
\hline $\mathrm{Sb}$ & 0.469 & 0.021 & 4.5 & 0.5 & 0.94 & 0.574 & 8.1 \\
\hline Cs & 8.83 & 0.07 & 0.8 & 7.57 & 1.17 & & \\
\hline $\mathrm{Ba}$ & 1133 & 14 & 1.2 & 1140 & 0.99 & & \\
\hline La & 40.2 & 0.3 & 0.9 & 37.9 & 1.06 & & \\
\hline $\mathrm{Ce}$ & 73.1 & 0.5 & 0.7 & 68.6 & 1.07 & & \\
\hline $\operatorname{Pr}$ & 8.83 & 0.07 & 0.8 & 7.57 & 1.17 & & \\
\hline $\mathrm{Nd}$ & 32.2 & 0.2 & 0.7 & 30.2 & 1.06 & & \\
\hline $\mathrm{Sm}$ & 5.93 & 0.07 & 1.2 & 5.49 & 1.08 & & \\
\hline
\end{tabular}




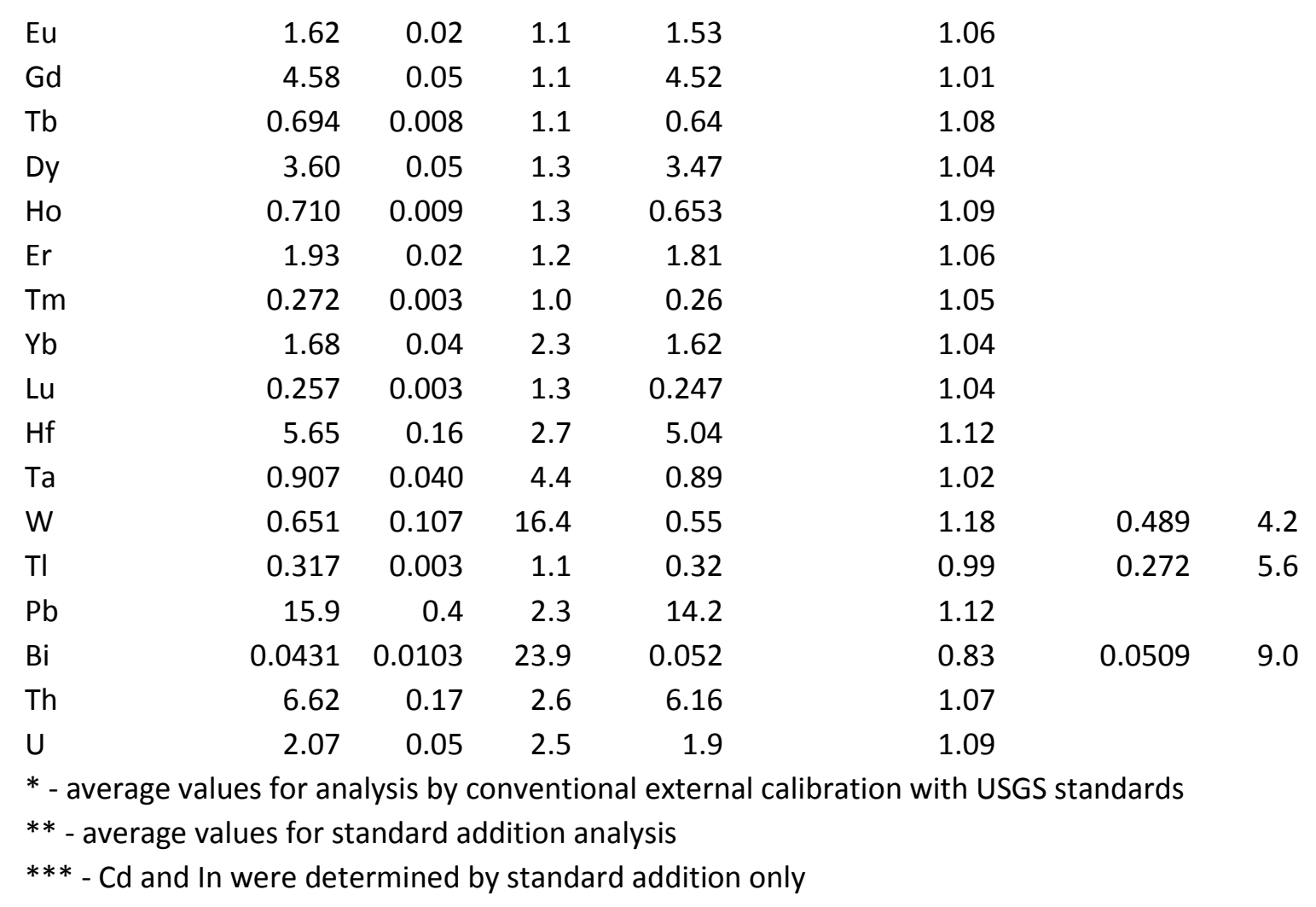


Table 4 - Proposed model for UCC based on Neoproterozoic and Paleozoic glacial diamictites Filtered to remove carbonate-rich samples

\begin{tabular}{|c|c|c|c|c|c|c|c|}
\hline $\begin{array}{l}\text { (in wt } \\
\%)\end{array}$ & $\begin{array}{c}\text { Filtered } \\
\text { Median } \\
\text { (Preferred } \\
\text { values) }\end{array}$ & $\begin{array}{c}\text { Median } \\
\text { absolute } \\
\text { deviation }\end{array}$ & $\begin{array}{l}\text { Unfiltere } \\
\text { d Median }\end{array}$ & $\begin{array}{c}\text { Median } \\
\text { absolute } \\
\text { deviatio } \\
n\end{array}$ & $\begin{array}{c}\text { differenc } \\
\text { e (filtered } \\
\text { vs } \\
\text { unfiltered } \\
\text { ) }\end{array}$ & $\mathrm{UCC}_{\mathrm{RG}}$ & $\underset{*}{\% R S D}$ \\
\hline $\mathrm{SiO} 2$ & 70.4 & 2.3 & 70.2 & 2.5 & $0 \%$ & 66.2 & $2 \%$ \\
\hline TiO2 & 0.7 & 0.08 & 0.7 & 0.08 & $0 \%$ & 0.63 & $13 \%$ \\
\hline $\mathrm{Al} 2 \mathrm{O} 3$ & 14.6 & 0.9 & 14.4 & 1.3 & $1 \%$ & 15.3 & $5 \%$ \\
\hline $\begin{array}{r}\mathrm{Fe} 2 \mathrm{O} 3 \\
\mathrm{~T}\end{array}$ & 5.5 & 0.64 & 5.6 & 1.3 & $-1 \%$ & 5.57 & $10 \%$ \\
\hline $\mathrm{MnO}$ & 0.1 & 0.03 & 0.1 & 0.04 & $-3 \%$ & 0.09 & $13 \%$ \\
\hline $\mathrm{MgO}$ & 2.0 & 0.35 & 2.2 & 0.42 & $-9 \%$ & 2.47 & $14 \%$ \\
\hline $\mathrm{CaO}$ & 1.4 & 0.63 & 1.7 & 0.85 & $-17 \%$ & 3.57 & $6 \%$ \\
\hline $\mathrm{Na} 2 \mathrm{O}$ & 1.6 & 0.70 & 1.5 & 0.70 & $7 \%$ & 3.25 & $15 \%$ \\
\hline K2O & 3.6 & 0.33 & 3.5 & 0.43 & $2 \%$ & 2.78 & $8 \%$ \\
\hline P2O5 & 0.2 & 0.03 & 0.2 & 0.03 & $2 \%$ & 0.15 & $15 \%$ \\
\hline
\end{tabular}

\begin{tabular}{|c|c|c|c|c|c|c|c|}
\hline $\mathrm{Li}$ & 31.3 & 5.2 & 31.4 & 5.8 & $0 \%$ & 24.0 & $21 \%$ \\
\hline $\mathrm{Be}$ & 2.34 & 0.41 & 2.19 & 0.59 & $7 \%$ & 2.08 & $41 \%$ \\
\hline Sc & 12.1 & 1.8 & 12.0 & 2.0 & $1 \%$ & 14.0 & $6 \%$ \\
\hline V & 73.8 & 7.2 & 75.0 & 12.1 & $-2 \%$ & 97.0 & $11 \%$ \\
\hline $\mathrm{Cr}$ & 53.0 & 10.8 & 55.7 & 14.5 & $-5 \%$ & 92.3 & $19 \%$ \\
\hline Co & 11.8 & 2.0 & 12.3 & 3.0 & $-4 \%$ & 17.3 & $3 \%$ \\
\hline $\mathrm{Ni}$ & 26.3 & 5.4 & 27.0 & 7.3 & $-3 \%$ & 47.3 & $24 \%$ \\
\hline $\mathrm{Cu}$ & 20.2 & 7.7 & 20.5 & 7.8 & $-1 \%$ & 27.7 & $14 \%$ \\
\hline $\mathrm{Zn}$ & 73.0 & 11.4 & 72.0 & 15.0 & $1 \%$ & 67.0 & $9 \%$ \\
\hline $\mathrm{Ga}$ & 18.2 & 2.1 & 17.6 & 2.5 & $3 \%$ & 17.5 & $4 \%$ \\
\hline $\mathrm{Ge}$ & 1.66 & 0.14 & 1.61 & 0.21 & $3 \%$ & 1.45 & $9 \%$ \\
\hline $\mathrm{Rb}$ & 110 & 20 & 106 & 21 & $4 \%$ & 82 & $20 \%$ \\
\hline $\mathrm{Sr}$ & 91.5 & 30.6 & 99.1 & 30.4 & $-8 \%$ & 320 & $14 \%$ \\
\hline $\mathrm{Y}$ & 33.2 & 4.5 & 31.0 & 5.0 & $7 \%$ & 21.0 & $11 \%$ \\
\hline $\mathrm{Zr}$ & 220 & 31 & 205 & 39 & $7 \%$ & 193 & $14 \%$ \\
\hline $\mathrm{Nb}$ & 12.7 & 1.8 & 12.4 & 2.1 & $2 \%$ & 11.8 & $12 \%$ \\
\hline Mo & 0.30 & 0.09 & 0.35 & 0.13 & $-15 \%$ & 1.13 & $28 \%$ \\
\hline $\mathrm{Cd}$ & 0.11 & 0.04 & 0.13 & 0.04 & $-21 \%$ & 0.089 & $15 \%$ \\
\hline In & 0.0620 & 0.0136 & 0.0593 & 0.0109 & $4 \%$ & 0.0555 & $14 \%$ \\
\hline Sn & 2.41 & 0.34 & 2.38 & 0.42 & $1 \%$ & 2.12 & $26 \%$ \\
\hline $\mathrm{Sb}$ & 0.418 & 0.174 & 0.382 & 0.156 & $9 \%$ & 0.375 & $28 \%$ \\
\hline Cs & 4.30 & 0.85 & 4.30 & 0.94 & $0 \%$ & 4.10 & $31 \%$ \\
\hline $\mathrm{Ba}$ & 731 & 113 & 696 & 121 & $5 \%$ & 624 & $13 \%$ \\
\hline $\mathrm{La}$ & 36.5 & 7.2 & 34.9 & 8.7 & $4 \%$ & 31.4 & $9 \%$ \\
\hline $\mathrm{Ce}$ & 72.9 & 16.5 & 70.0 & 18.5 & $4 \%$ & 63.4 & $6 \%$ \\
\hline $\mathrm{Pr}$ & 8.54 & 1.87 & 8.25 & 1.95 & $3 \%$ & 7.10 & \\
\hline $\mathrm{Nd}$ & 33.3 & 6.9 & 31.5 & 6.7 & $6 \%$ & 27.0 & $8 \%$ \\
\hline $\mathrm{Sm}$ & 6.84 & 1.21 & 6.36 & 1.34 & $7 \%$ & 4.70 & $6 \%$ \\
\hline
\end{tabular}




$\begin{array}{cccccccc}\mathrm{Eu} & 1.37 & 0.23 & 1.31 & 0.26 & 4 \% & 1.02 & 14 \% \\ \mathrm{Gd} & 6.05 & 1.18 & 5.60 & 1.07 & 8 \% & 4.01 & 7 \% \\ \mathrm{~Tb} & 0.983 & 0.162 & 0.920 & 0.174 & 7 \% & 0.650 & 1 \% \\ \mathrm{Dy} & 5.57 & 0.82 & 5.28 & 0.96 & 5 \% & 3.91 & \\ \mathrm{Ho} & 1.13 & 0.16 & 1.08 & 0.19 & 4 \% & 0.83 & \\ \mathrm{Er} & 3.27 & 0.46 & 3.08 & 0.55 & 6 \% & 2.30 & \\ \mathrm{Tm} & 0.506 & 0.069 & 0.487 & 0.080 & 4 \% & 0.300 & \\ \mathrm{Yb} & 3.07 & 0.33 & 3.02 & 0.45 & 1 \% & 2.04 & 18 \% \\ \mathrm{Lu} & 0.479 & 0.053 & 0.464 & 0.067 & 3 \% & 0.306 & 17 \% \\ \mathrm{Hf} & 6.50 & 1.00 & 5.98 & 1.18 & 8 \% & 5.26 & 14 \% \\ \mathrm{Ta} & 0.940 & 0.131 & 0.901 & 0.152 & 4 \% & 0.882 & 13 \% \\ \mathrm{~W} & 1.10 & 0.16 & 1.11 & 0.15 & -1 \% & 1.90 & 54 \% \\ \mathrm{TI} & 0.588 & 0.187 & 0.544 & 0.179 & 8 \% & 0.941 & 57 \% \\ \mathrm{~Pb} & 15.8 & 5.1 & 15.1 & 4.9 & 5 \% & 17.0 & 3 \% \\ \mathrm{Bi} & 0.24 & 0.08 & 0.22 & 0.09 & 8 \% & 0.16 & 38 \% \\ \mathrm{Th} & 11.3 & 3.1 & 10.5 & 3.1 & 7 \% & 10.1 & 10 \% \\ \mathrm{U} & 2.66 & 0.87 & 2.40 & 0.99 & 10 \% & 2.63 & 21 \%\end{array}$

* - \%RSD is based on uncertainties reported in Rudnick and Gao (2003) 
Table 5. Average upper crustal abundances of select infrequently analyzed elements derived from corre UCC from

Table 4

Correlation (diamictite

Best Est. $^{*} \quad$ uncertainty derived ${ }^{* *}$ uncertainty Pinning elemen median)

uncertaint)

\begin{tabular}{l|rr|rc|rr|}
$\mathrm{Be}$ & 2.4 & 0.4 & 1.8 & $0.1 \mathrm{Sm}$ & 2.2 & 0.6 \\
$\mathrm{Ga}$ & 17.6 & 1.2 & 19.3 & $1.1 \mathrm{Al}$ & 17.6 & 2.5 \\
$\mathrm{In}$ & 0.066 & 0.009 & 0.044 & $0.003 \mathrm{Tm}$ & 0.059 & 0.011 \\
$\mathrm{Sn}$ & 2.54 & 0.30 & 1.74 & $0.27 \mathrm{Yb}$ & 2.38 & 0.42 \\
$\mathrm{TI}$ & 0.69 & 0.13 & 0.52 & $0.12 \mathrm{Rb}$ & 0.54 & 0.18
\end{tabular}

All concentrations in ppm

* - Neoproterozoic/Paleozoic diamictite median for pinning element is used to calculate element of inter

** - Rudnick and Gao (2003) estimate for pinning element is used to calculate element of interest 
FIGURES
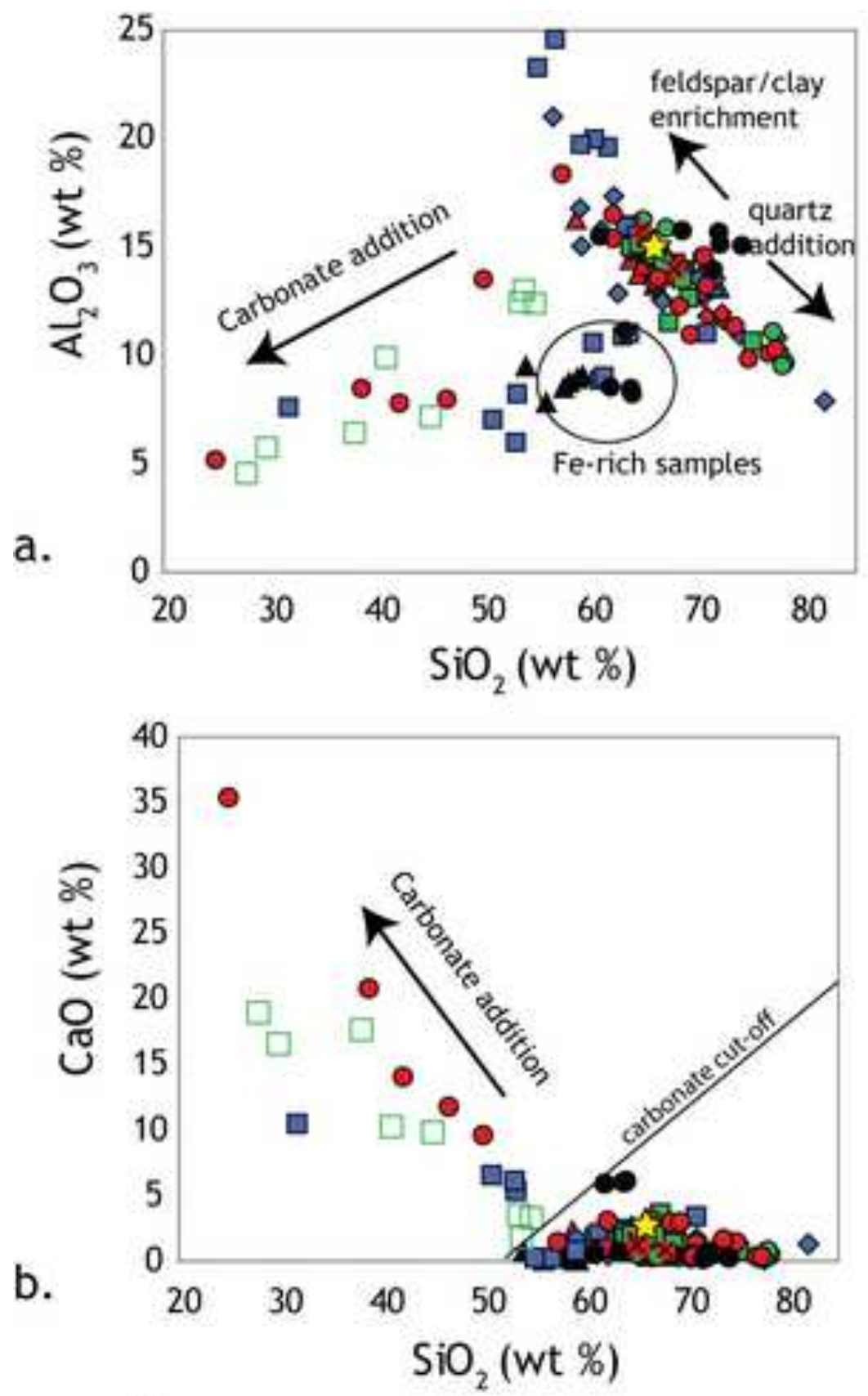

STUCC

Paleozoic

$\square$ South Africa - W Dwyka

- South Africa - E Dwyka

- Bolivia

Neoproterozoic

घ Virginia

- Idaho

$\triangle$ China

- Namibia

* Newfoundland

Paleoproterozoic

$\Delta$ Wyoming

- Ontario

- South Africa

Mesoarchean

A South Africa, Mozaan

- South Africa, Wits

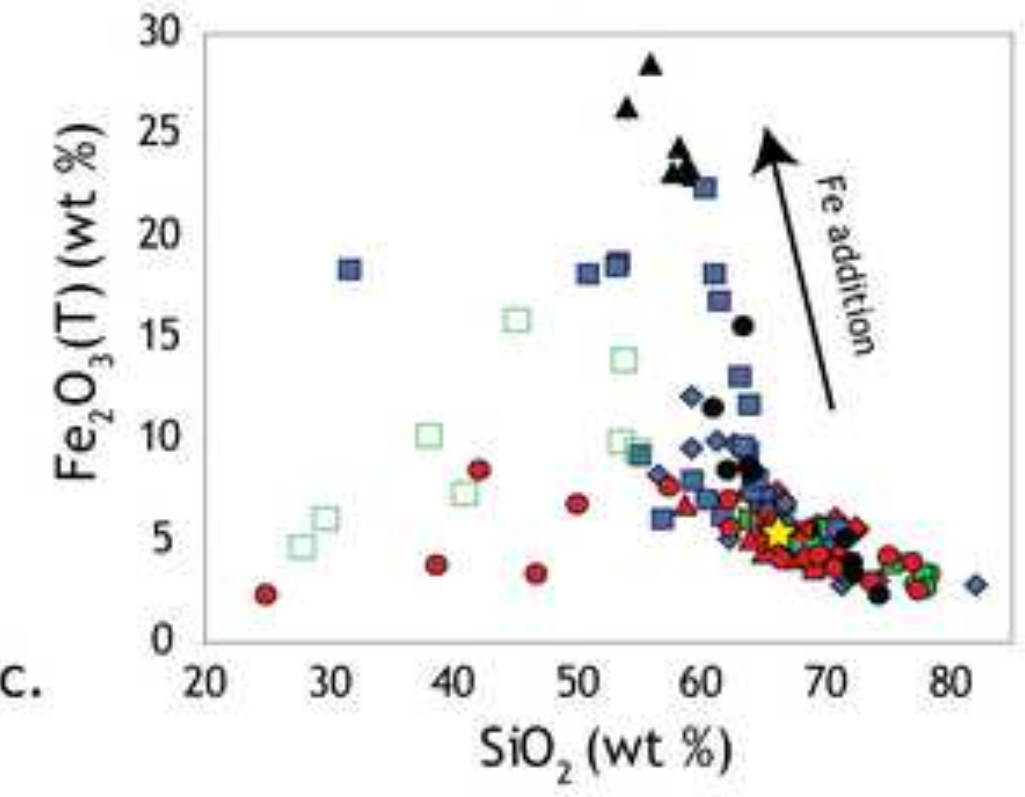



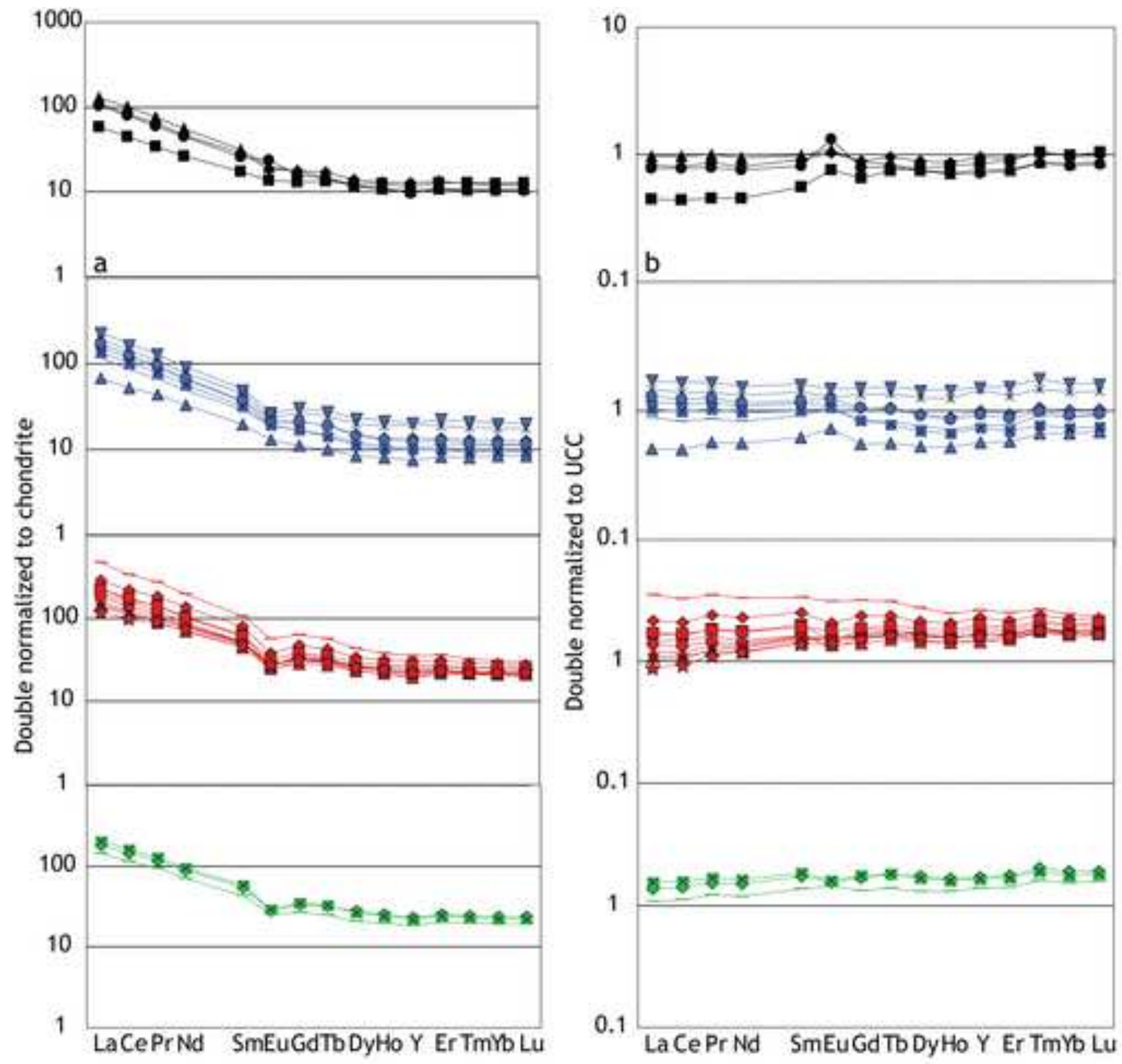

\section{Mesoarchean}

- South Africa - Mozaan

- South Africa - Wits - Afrikander

A-South Africa - Wits - Coronation

- South Africa - Wits - Promise

\section{Paleoproterozoic}

\section{- Ontario - Ramsay Lake \\ w Ontario-Gowganda \\ - Ontario-Bruce \\ A- Wyoming - Bottle Creek \\ *-South Africa - Makganyene \\ - South Africa - Timeball Hill \\ $\checkmark$ South Africa - Duitschland}

\section{Neoproterozoic}

- Virginía - Konnarock

* Newfoundland-Gaskiers

- Idaho-Pocatello

^ China - Nantuo \& Gucheng

- Namibia - Blaubeker

- Namibia - Kaigas \& Chuos

- Namibia - Numees

* Namibia - Ghaub

\section{Paleozoic}

- Bolivia - Machareti \& Mandiyuti

ॠ South Africa - east Dwyka

- South Africa - west Dwyka 

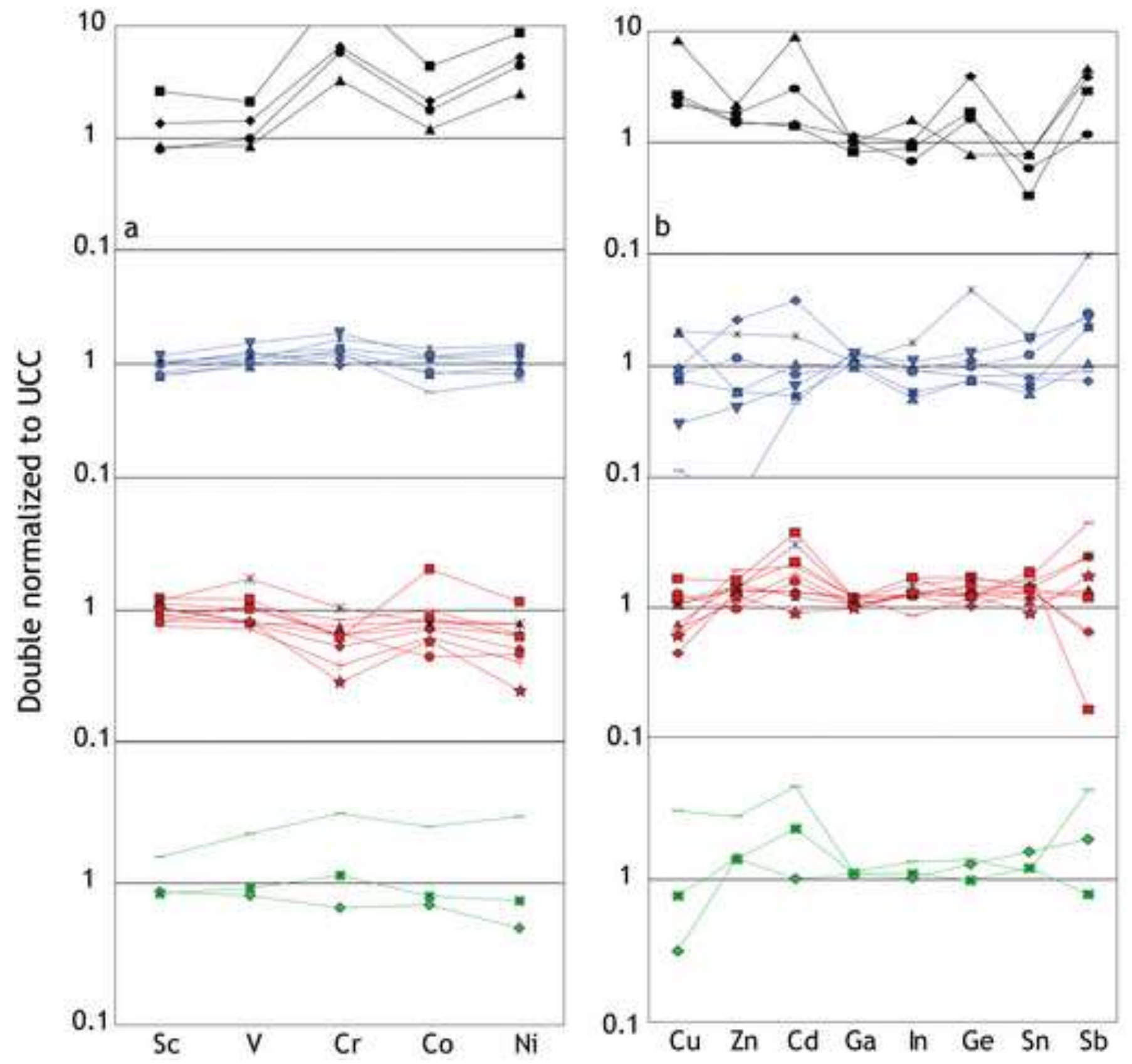

\section{Mesoarchean}

- South Africa - Mozaan

- South Africa - Wits - Afrikander

- South Africa - Wits - Coronation

- South Africa - Wits - Promise

\section{Paleoproterozoic}

- Ontario - Ramsay Lake
n Ontario - Gowganda
- Ontario - Bruce
- Wyoming - Bottle Creek
- South Africa - Makganyene
- South Africa - Timeball Hill
- South Africa - Duitschland

\section{Neoproterozoic}

- Virginia - Konnarock

- Newfoundland-Gaskiers

- Idaho - Pocatello

^. China - Nantuo \& Gucheng

- Namibia - Blaubeker

- Namibia - Kaigas \& Chuos

Namibia-Numees

x-Namibia-Ghaub

\section{Paleozoic}

- Bolivia - Machareti \& Mandiyutí

* South Africa - east Dwyka

- South Africa - west Dwyka 

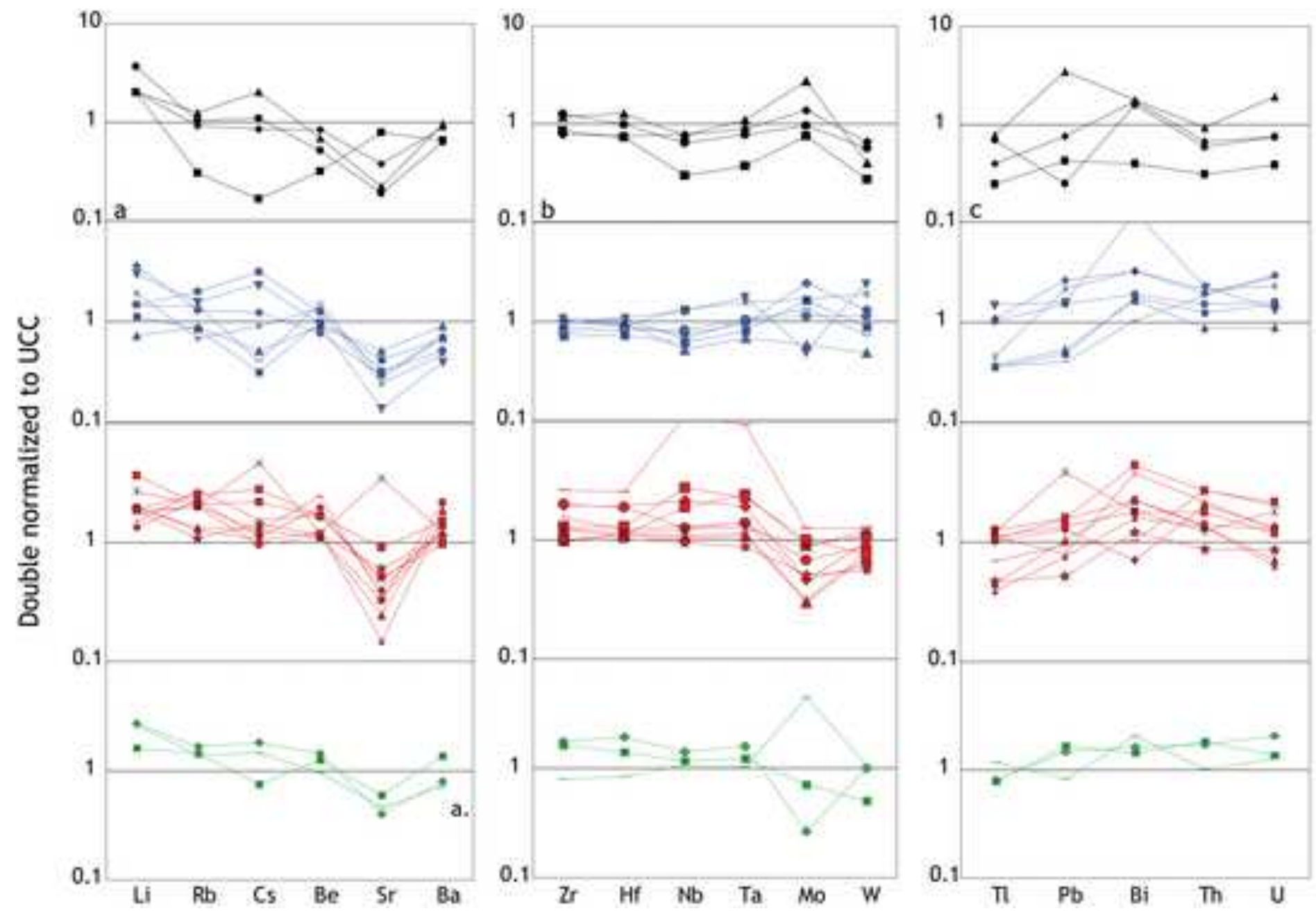

\section{Mesoarchean}

- South Africa - Mozaan

- South Africa - Wits - Afrikander

- South Africa - Wits - Coronation

- South Africa - Wits - Promise

Pateoproterozoic

- Ontario - Ramsay Lake

w Ontario-Gowganda

- Ontario - Bruce

- Wyoming-Bottle Creek

w South Africa - Makganyene

- South Africa - Timeball Hill

- South Africa - Duitschland

Neoproterozoic

- Virginia - Konnarock

- Newfoundland - Gaskiers

daho - Pocatello

4. China-Nantuo \& Gucheng

- Namibia - Blaubeker

- Namibia - Kaigas and Chuos

Namibia - Numees

Namibia - Ghaub

Paleozoic

+ Bolivia - Machareti \& Mandiyuti

- South Africa - east Dwyka

South Africa - west Dwyka 

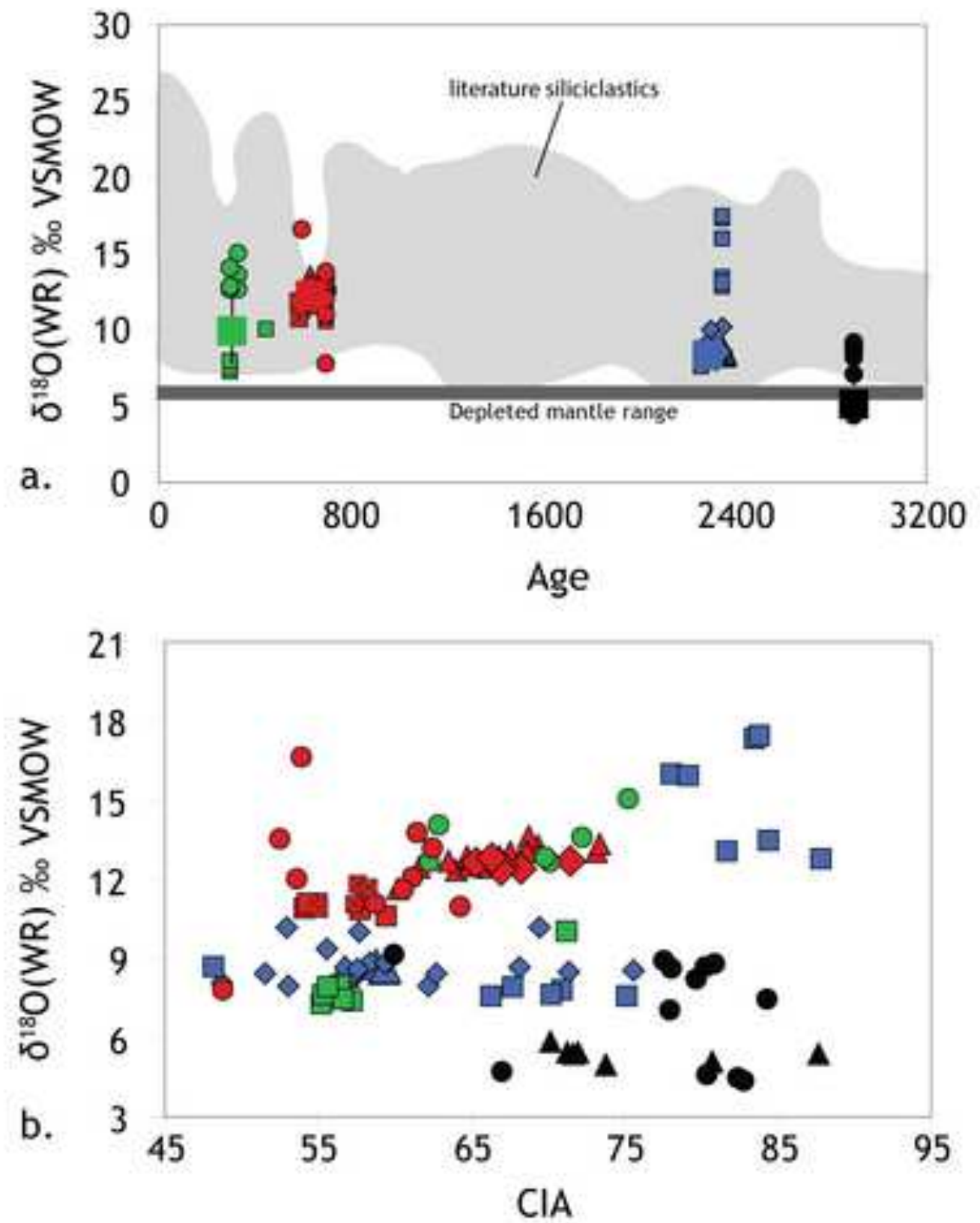

\section{Paleozoic}

口 South Africa

- Bolivia

Neoproterozoic

- Virginia

- Idaho

a Namibia

Newtoundland

Paleoproterozoic

$\Delta$ Wyoming

- Ontario

- South Africa

Meșoarchean

A South Africa, Mozaan

- South Africa, Wits 

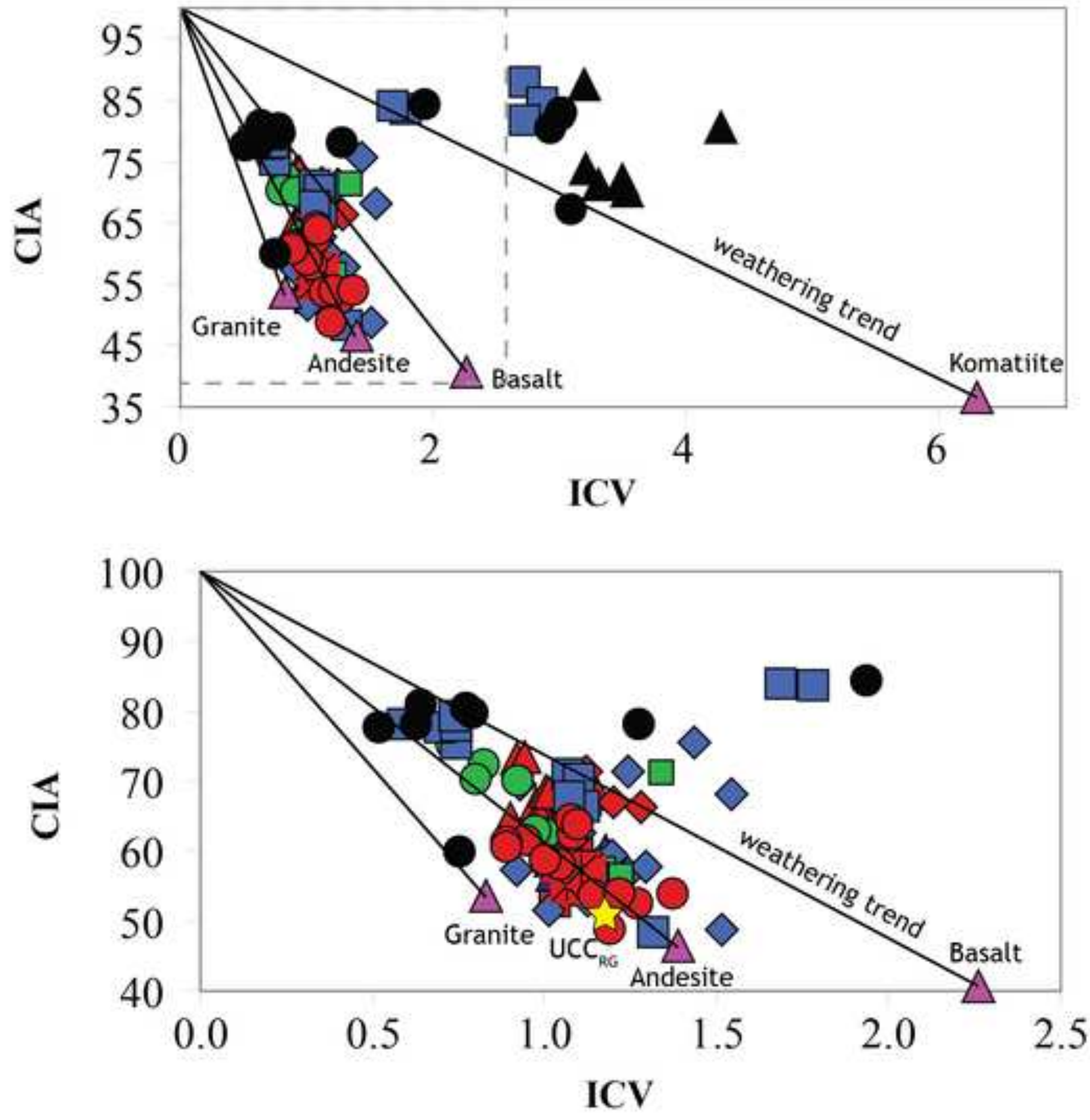

$\hat{\mathrm{J}} \mathrm{UCC}_{\mathrm{RG}}$

Paleozoic

$\square$ South Africa

- Bolivia

Neoproterozoic

口 Virginia

$\diamond$ Idaho

$\triangle$ China

- Namibia

* Newfoundland

Paleoproterozoic

$\Delta$ Wyoming

$\diamond$ Ontario

曰 South Africa

Mesoarchean

$\Delta$ South Africa, Mozaan

- South Africa, Wits 


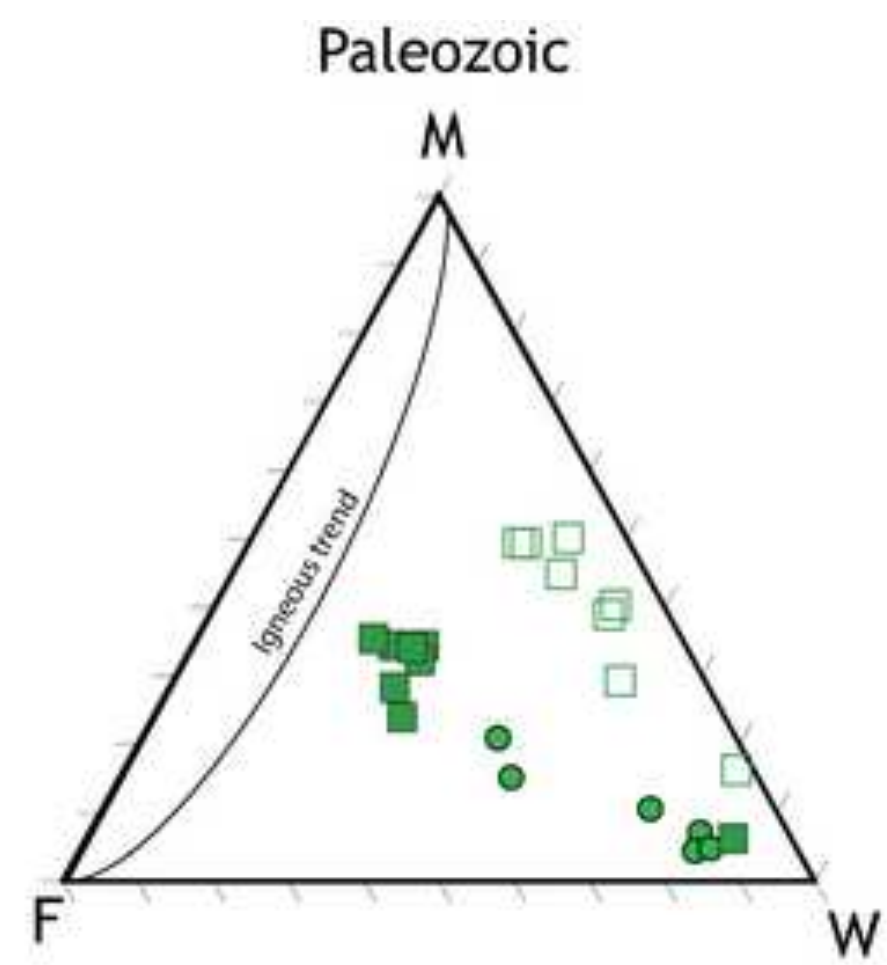

Paleoproterozoic

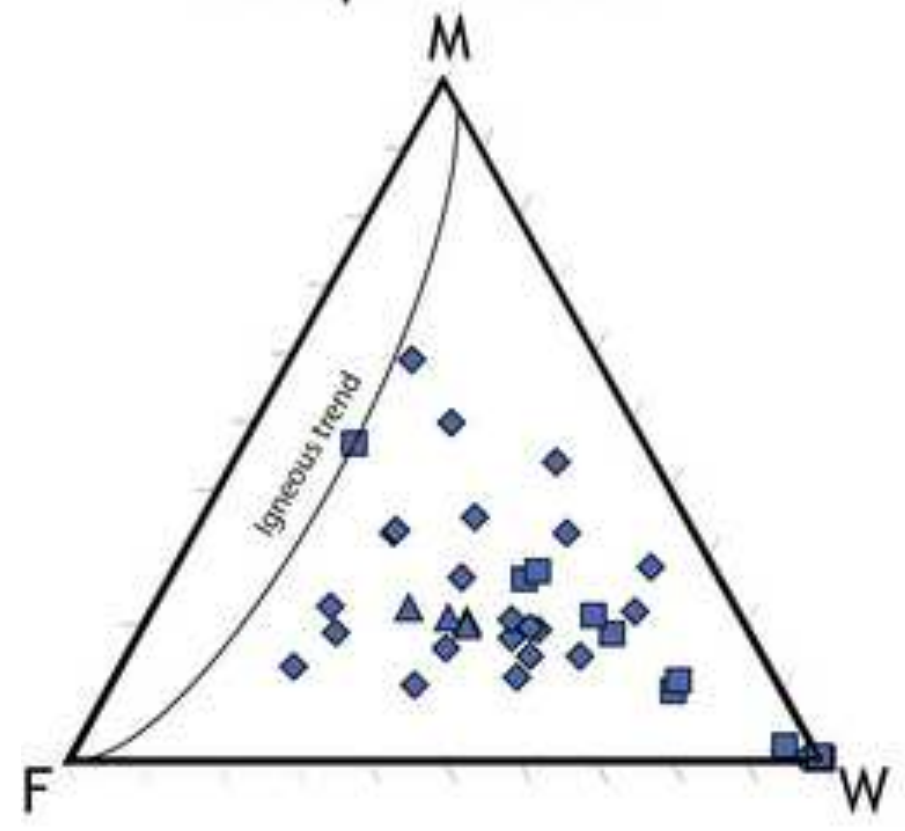

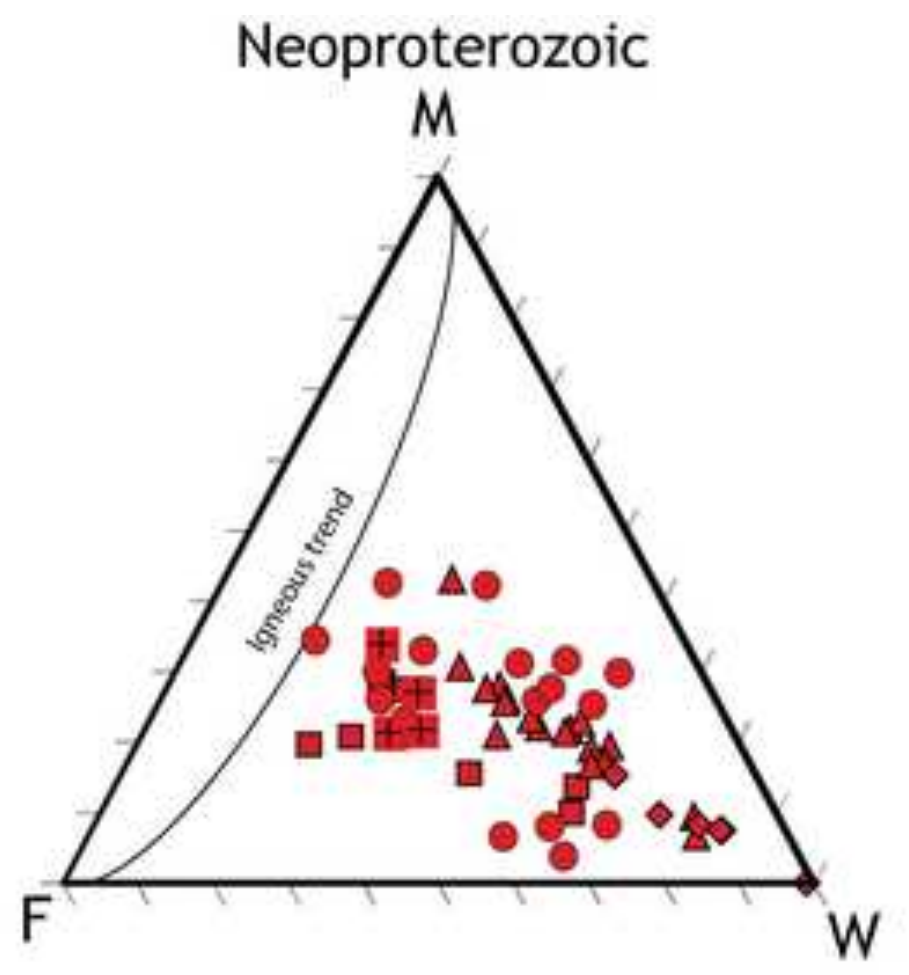

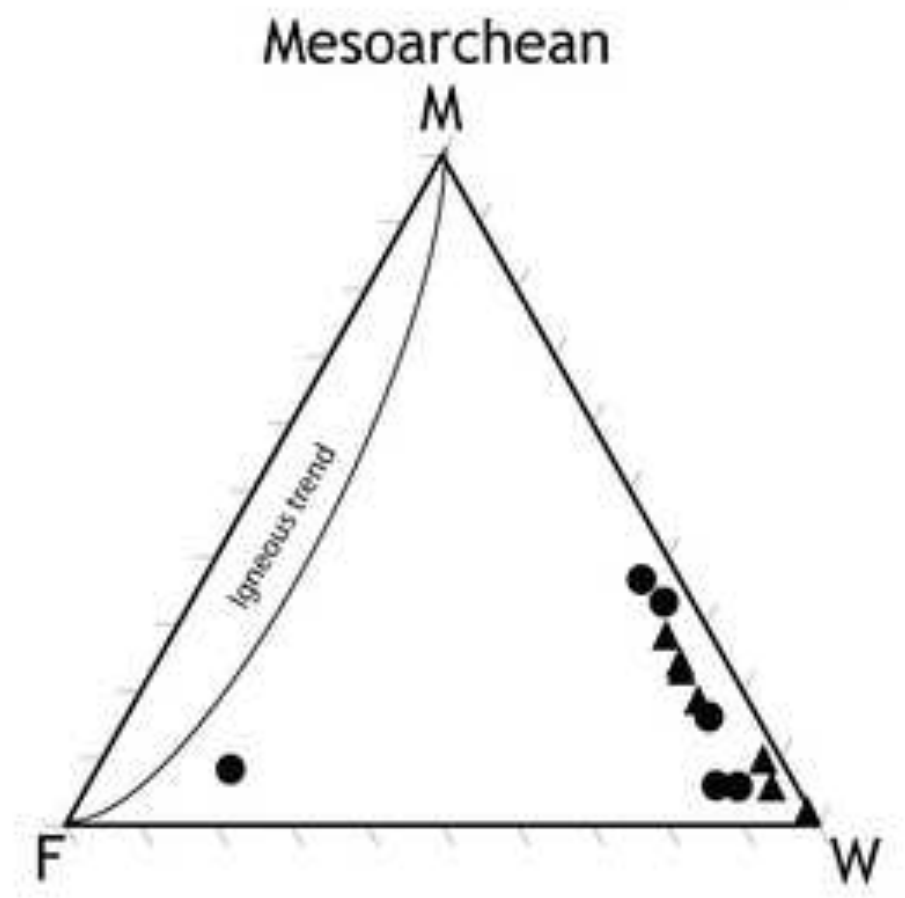

Paleozoic

$\square$ South Africa (W Dwyka)

a South Africa (E Dwyka)

- Bolivia

Neoproterozoic

ㅁ Virginia

- Idaho

$\triangle$ China

- Namibia

I Newfoundland

Paleoproterozoic

$\Delta$ Wyoming

\& Ontario

- South Africa Mesoarchean

A South Africa, Mozaan

- South Africa, Wits 

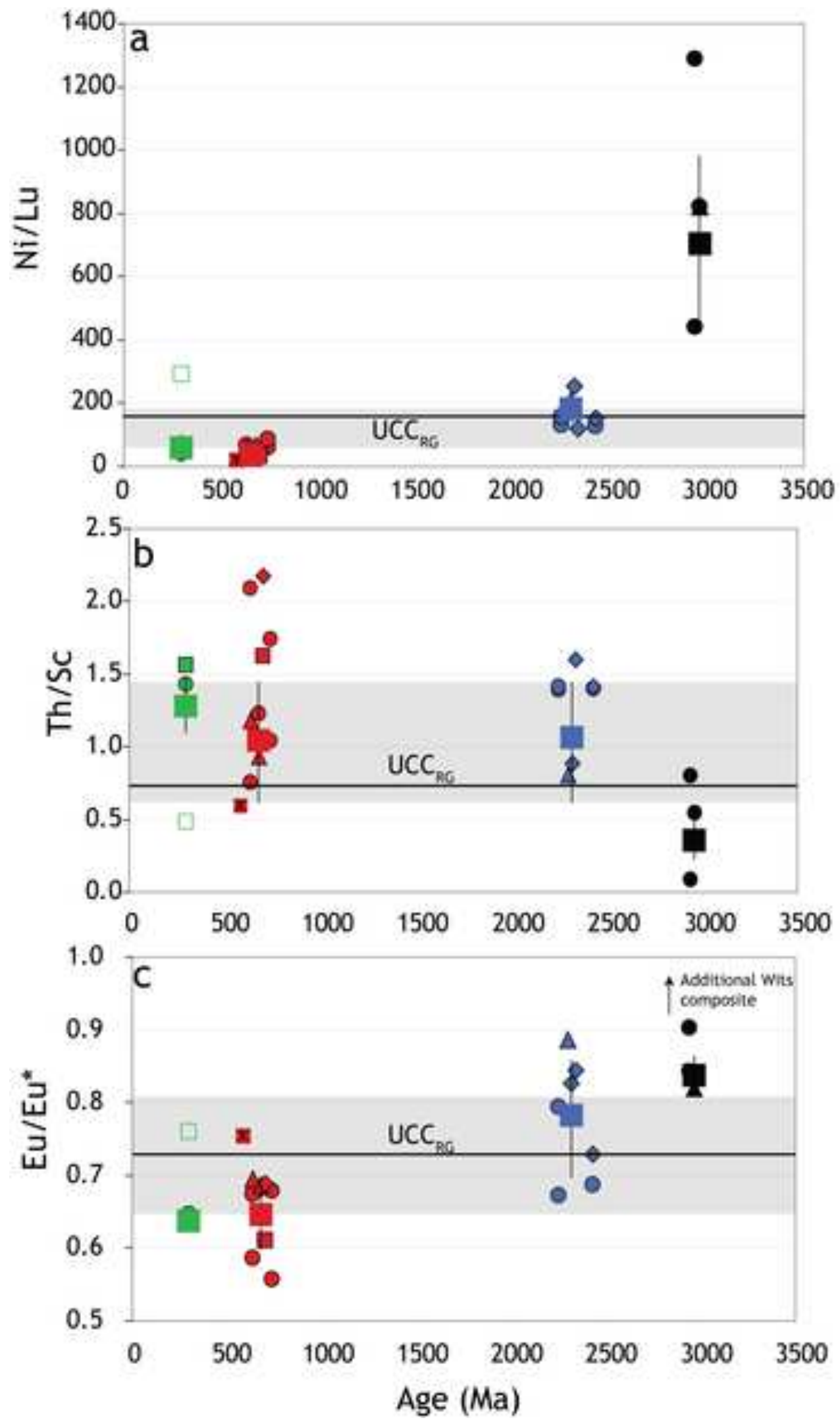

\section{Paleozoic}

$\square$ South Africa

- South Africa

- Bolivia

Neoproterozoic

- Virginia

- Idaho

$\Delta$ China

- Namibia

Newfoundland

Paleoproterozoic

A Wyoming

- Ontario

- South Africa

Mesoarchean

A South Africa, Mozaan

- South Africa, Wits 

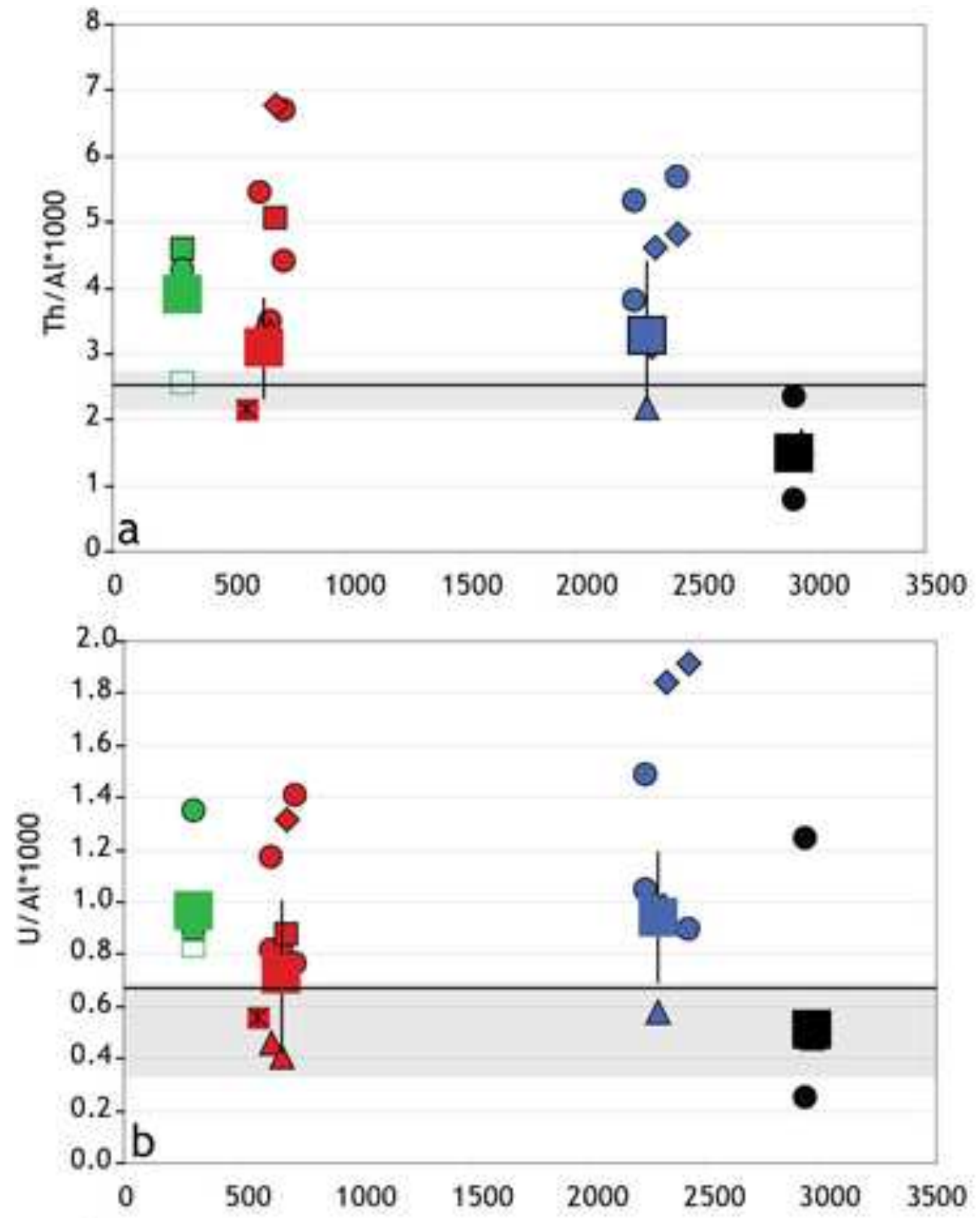

Paleozoic

$\square$ South Africa (W Dwyka)

- South Africa (E Dwyka)

- Bolivia

Neoproterozoic

口 Virginia

- Idaho

$\triangle$ China

- Namíbia

Newfoundland

Paleoproterozoic

$\Delta$ Wyoming

- Ontario

- South Africa

Mesoarchean

A South Africa, Mozaan

- South Africa, Wits

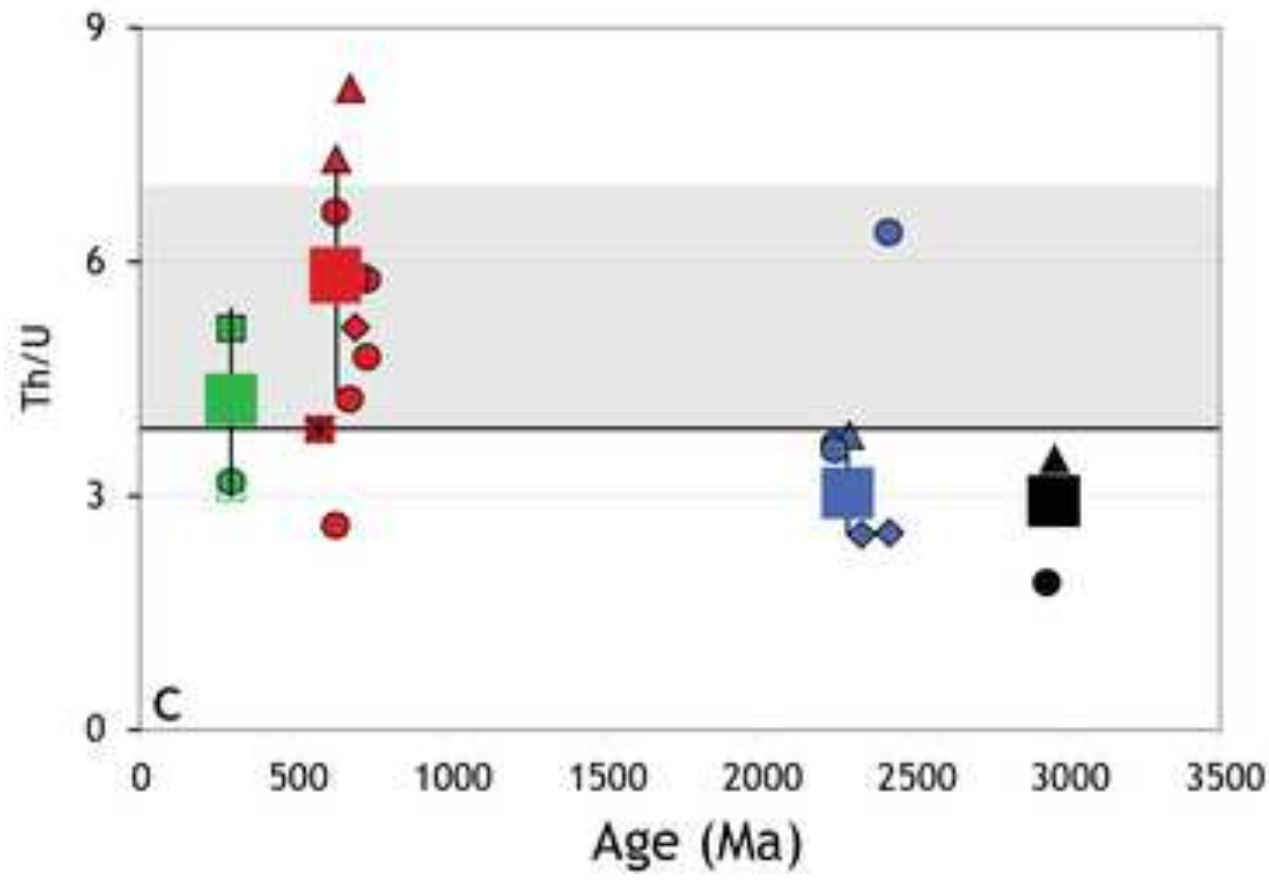



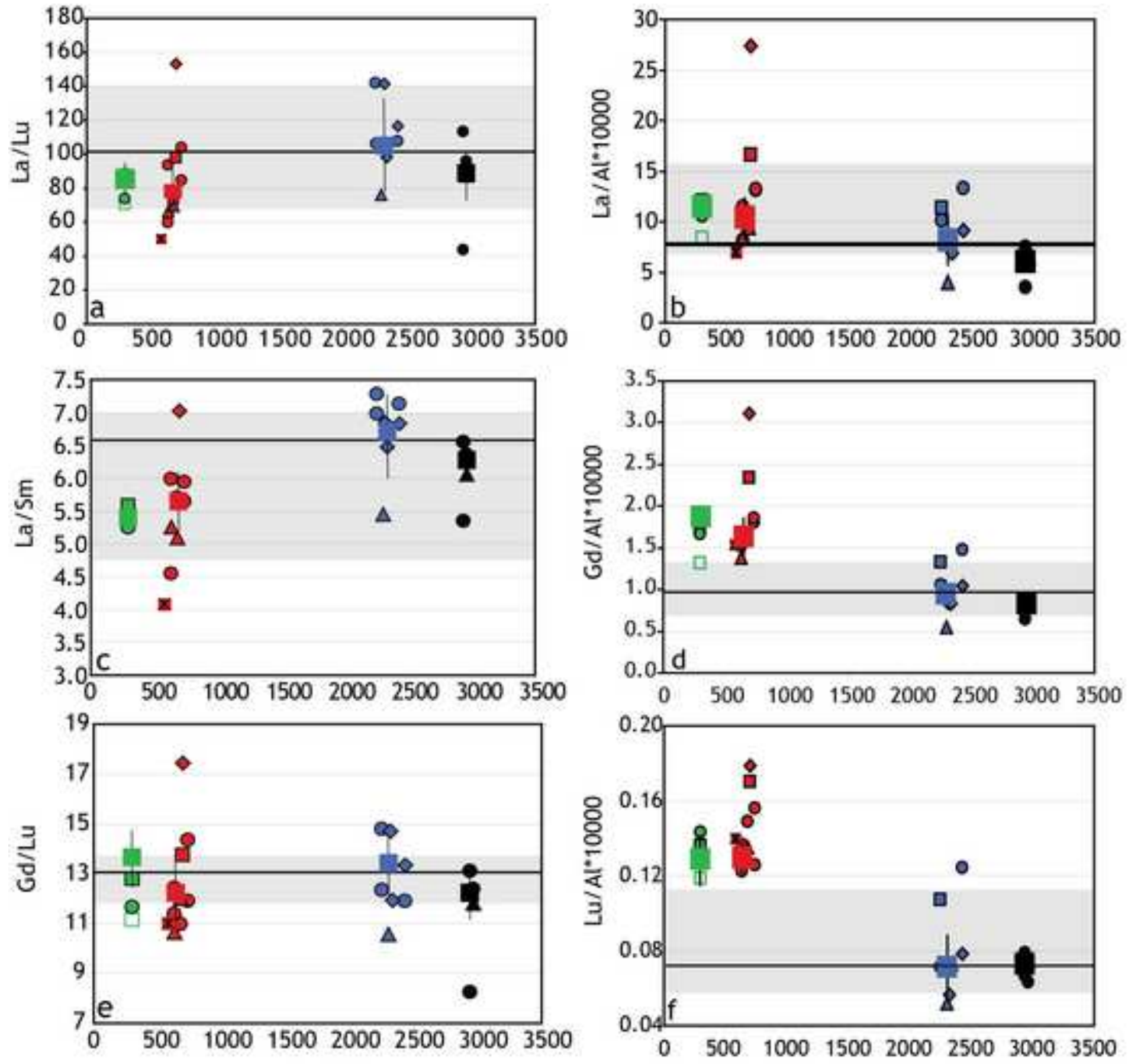

Paleozoic

$\square$ South Africa (W Dwyka)

- South Africa (E Dwyka)

- Bolivia

Neoproterozoic

日 Virginia

$\checkmark$ Idaho

$\triangle$ China

- Namibia

* Newfoundland

Paleoproterozoic

$\Delta$ Wyoming

O Ontario

- South Africa

Mesoarchean

A South Africa, Mozaan

- South Africa, Wits 

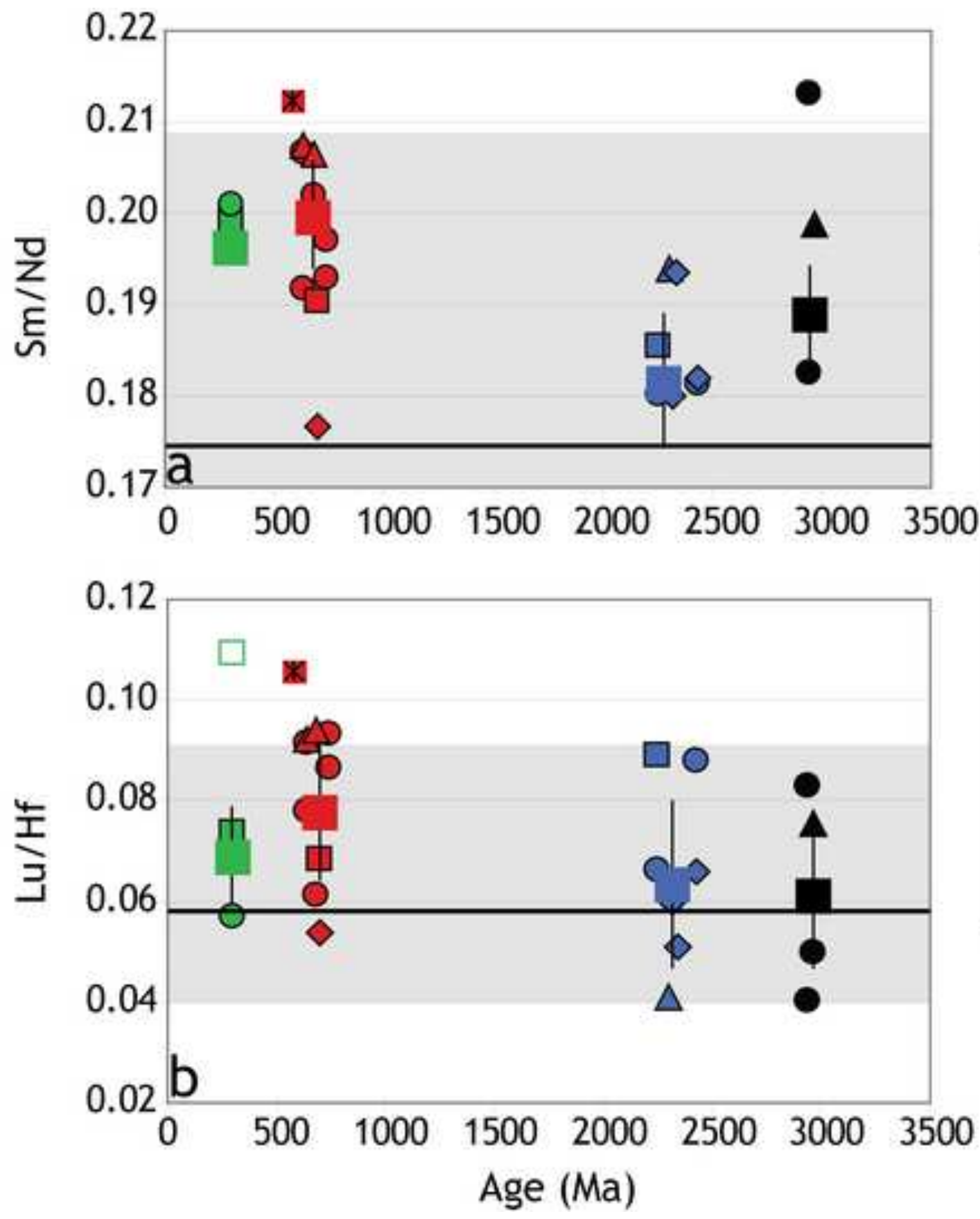

Paleozoic

$\square$ South Africa (W Dwyka)

$\square$ South Africa (E Dwyka)

- Bolivia

Neoproterozoic

ㅁ Virginia

$\diamond$ Idaho

$\triangle$ China

- Namibia

* Newfoundland

Paleoproterozoic

$\Delta$ Wyoming

$\diamond$ Ontario

- South Africa

Mesoarchean

$\Delta$ South Africa, Mozaan

- South Africa, Wits 

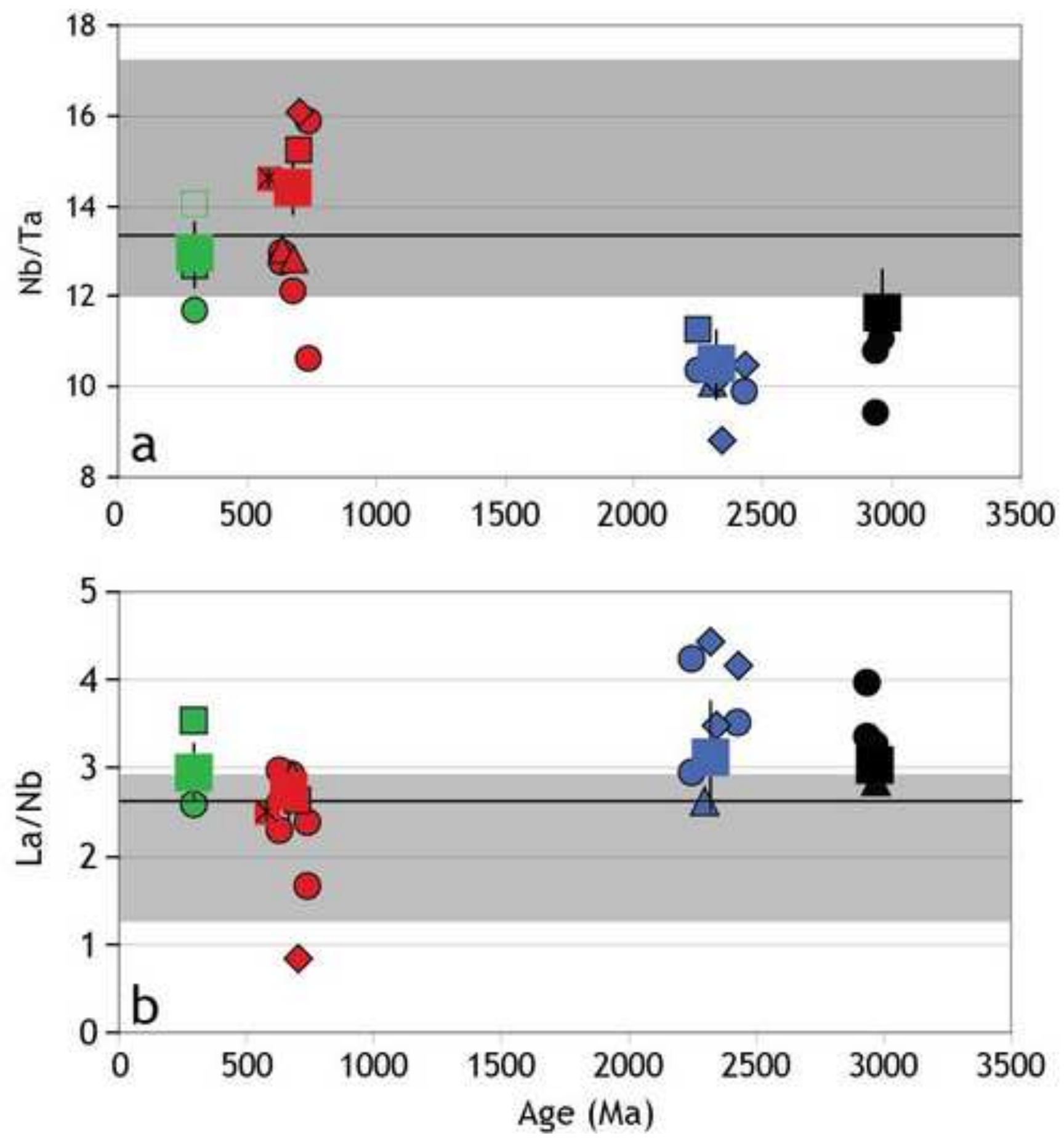

Paleozoic

$\square$ South Africa (W Dwyka)

$\square$ South Africa (E Dwyka)

O Bolivia

Neoproterozoic

$\square$ Virginia

$\checkmark$ Idaho

$\triangle$ China

- Namibia

* Newfoundland

Paleoproterozoic

$\triangle$ Wyoming

$\diamond$ Ontario

- South Africa

Mesoarchean

$\Delta$ South Africa, Mozaan

- South Africa, Wits 

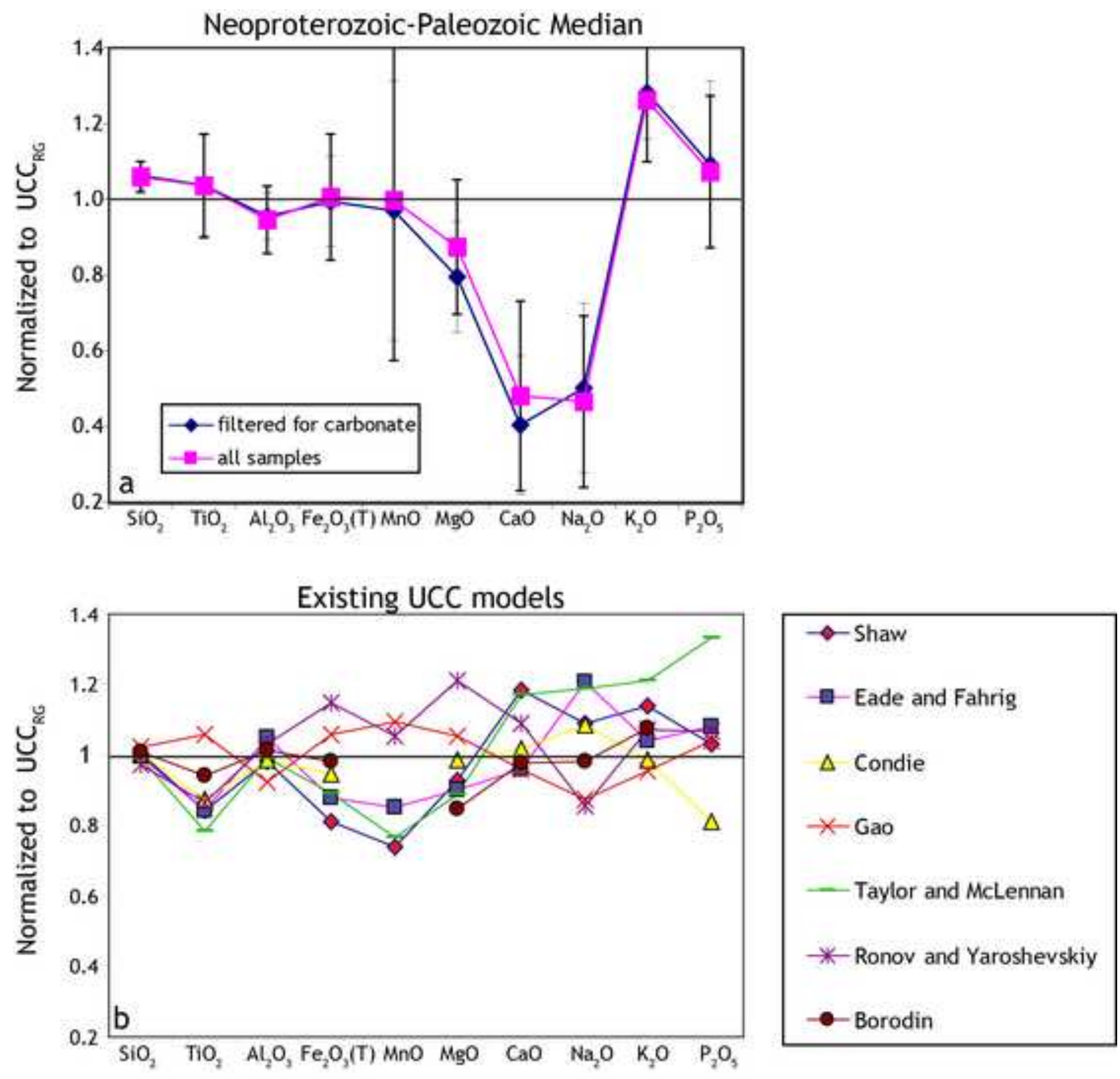


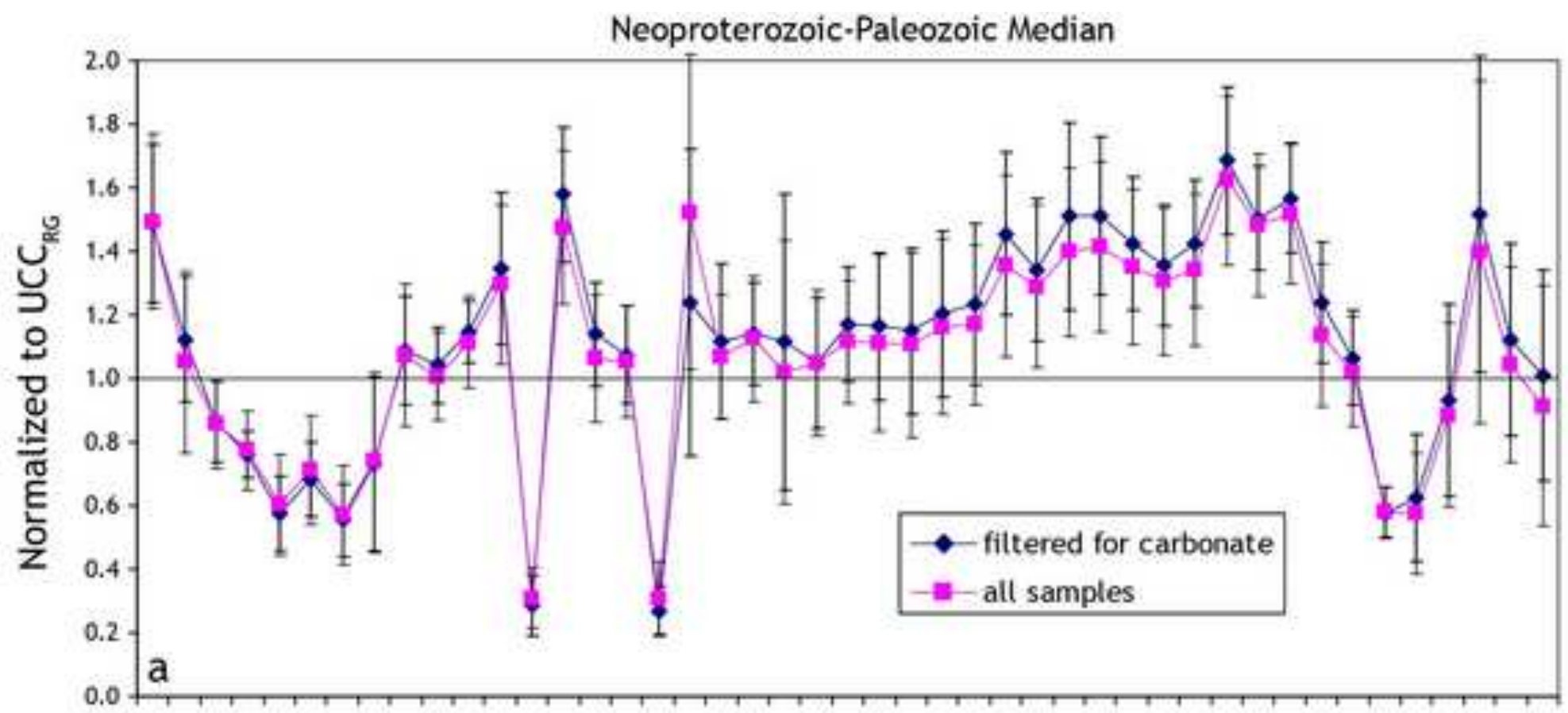

Li Be Sc V CrCo NiCuZnGaGe Rb Sr Y ZrNbMoCd in Sn Sb CS Ba LaCe Pr NdSmEuGdTb DyHo ErTmYb Lu Hf Ta W TI Pb Bi Th U

Existing UCC models

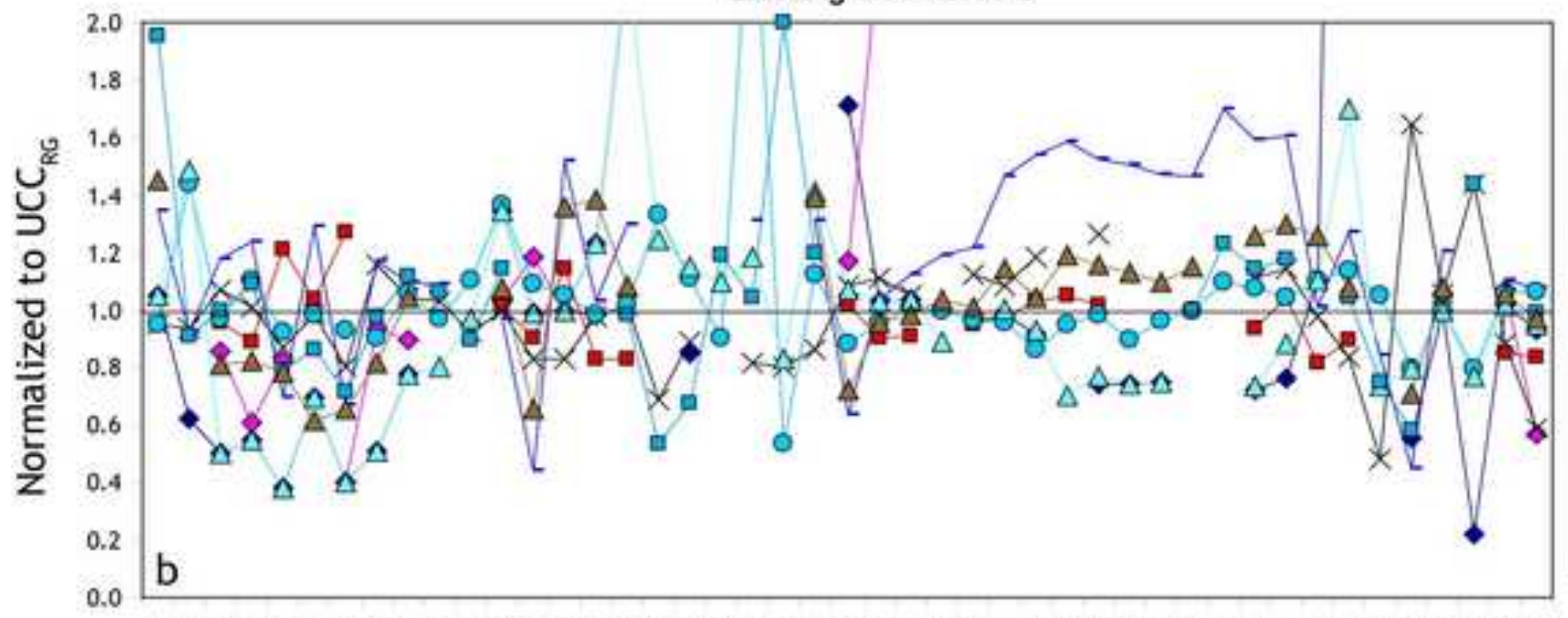

- Shaw

- Eade and Fahrig

- Condie

$\rightarrow$ Gao

- Kamber

- Taylor and McLennan

$\triangle$ Wedepohl

- Hu and Gao

$\triangle$ Chauvel

Li BeSc V CrCo NiCuZnGaGeRb Sr Y Zr NbMoCd In Sn SbCs BaLaCe PrNdSmEu GdTb DyHo Er TmYb Lu Hf Ta W TI Pb Bi Th U 

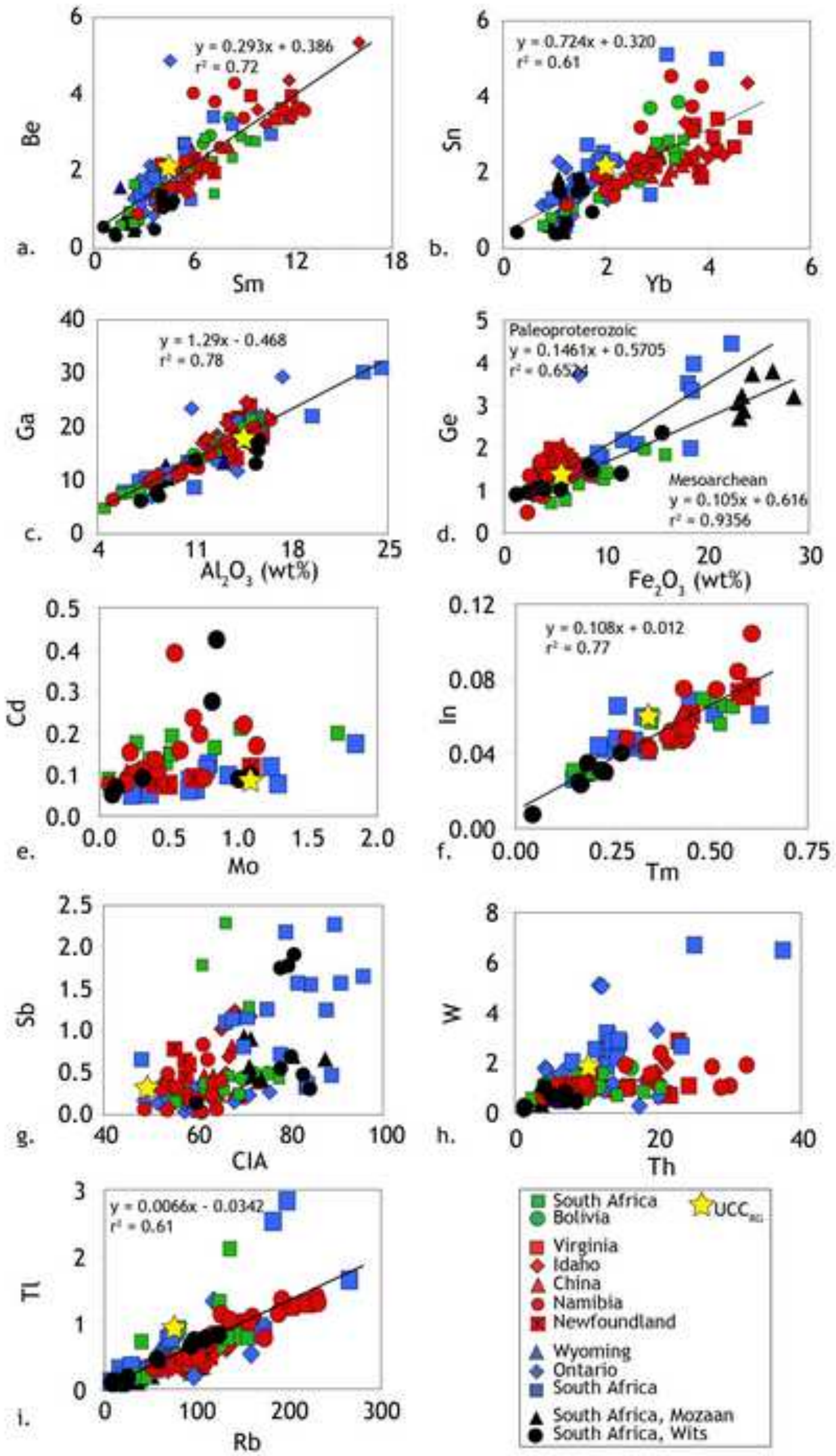

\begin{tabular}{|c|}
\hline $\begin{array}{l}\text { a South Africa } \\
\text { Bolivia }\end{array}$ \\
\hline $\begin{array}{l}\text { Virginia } \\
\text { Idaho } \\
\text { A China } \\
\text { Namibia } \\
\text { a Newfoundtand }\end{array}$ \\
\hline $\begin{array}{l}\text { Wyoming } \\
\text { Ontario } \\
\text { South Africa }\end{array}$ \\
\hline $\begin{array}{l}\text { A South Africa, Mozaan } \\
\text { South Africa, Wits }\end{array}$ \\
\hline
\end{tabular}

